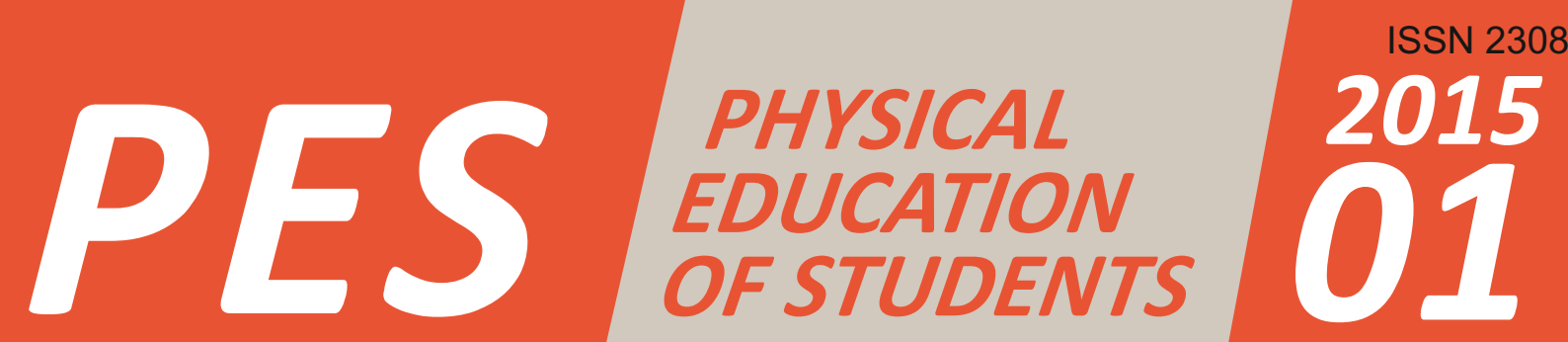


Key title: Fiziceskoe vospitanie studentov

Abbreviated key title: Fiz. vosp. stud.

ISSN 2075-5279 (Russian ed. Print), ISSN 2223-2125

(Russian ed. On line),

Key title: Physical education of students

Abbreviated key title: Phys. educ. stud.

ISSN 2308-7250 (English ed. Online)

Founders: Kharkov National Pedagogical University

Editor-in-chief:

lermakov S.S., Kharkov, Ukraine.

Editorial college:

Zaporozhanov V.A., Olsztyn, Poland (Scientific consultant).

Abdelkrim Bensbaa, Abu Dhabi, UAE.

Antala Branislav, Bratislava, Slovakia.

Boraczynski Tomasz, Olsztyn, Poland.

Boychenko S.D., Minsk, Byelorussia.

Boychuk U.D., Kharkov, Ukraine.

Cieślicka Mirosława, Bydgoszcz, Poland.

Corona Felice, Salerno, Italy.

Dmitriev S.V., Lower Novgorod, Russia.

Fathloun Mourad, Kef, Tunisia.

Görner Karol, Banska Bystrica, Slovakia.

Giovanis Vassilios, Athens, Greece.

Jagello Wladislaw, Gdans'k, Poland.

Jorge Alberto Ramirez Torrealba, Maracay, Venezuela.

Khudolii O.M., Kharkov, Ukraine.

Ionova O.M., Dornach, Switzerland.

Kozina Z.L., Radom, Poland.

Korobeynikov G.V., Kiev, Ukraine.

Leikin M.G., Portland, USA.

Malinauskas Romualdas, Kaunas, Lithuania.

Maciejewska-Karlowska Agnieszka, Szczecin, Poland.

Nosko N.A., Chernigov, Ukraine.

Prusik Katarzyna, Gdans'k, Poland.

Prusik Krzysztof, Gdans'k, Poland.

Sawczuk Marek, Szczecin, Poland.

Sobyanin F.I., Belgorod, Russia.

Tkachuk V.G., Kiev, Ukraine.

Yan Wan Jun, Shijiazhuang, China.
A journal is ratified the MES of Ukraine: physical education and sport, pedagogical sciences (№1528, 29.12.2014; №1279, 06.11.2014).

Journal is reflected in databases:

Academic Journals Database

http://journaldatabase.org

BASE (Bielefeld Academic Search Engine)

http://www.base-search.net

CORE

http://core.kmi.open.ac.uk

CABI (CAB Direct)

http://www.cabdirect.org/

DIIRJ (Directory Indexing of International Research

Journals) http://drji.org/

DOAJ (Directory of Open Access Journals)

http://www.doaj.org

IndexCopernicus

http://journals.indexcopernicus.com

Google Scholar

http://scholar.google.com.ua

OAJI (Open Academic Journals Index)

http://oaji.net/journal-detail.html?number $=770$

Open Science Directory

http://www.opensciencedirectory.net

PBN (Polish Scholarly Bibliography)

https://pbn.nauka.gov.pl/journals/42127

ROAD (Directory of Open Access scholarly Resources)

http://road.issn.org

SHERPA/RoMEO http://www.sherpa.ac.uk

WorldCat http://www.worldcat.org

WorldWideScience Alliance http://worldwidescience.org

Ulrich's Periodicals Directory

http://ulrichsweb.serialssolutions.com/login

V.I.Vernadskiy National Library of Ukraine

http://www.nbuv.gov.ua

Electronic Library of Russia (Russian science citation index)

http://elibrary.ru

Library of the Russian state university of physical

culture, sport and tourism

http://lib.sportedu.ru/Press/FVS

Certificate to registration:

KB 20682-10482PR от 31.03.2014.

Frequency - 6 numbers in a year.

Address of editorial office:

P.O.Box 11135, Kharkov-68, 61068, Ukraine

Tel. 38-057-755-73-58

http://www.sportedu.org.ua

e-mail: sportart@gmail.com

Address of editorial office (Poland):

Sport str. 2, of.209, 85-064 Bydgoszcz, Poland

Editor-in-Chief: Sergii lermakov, tel.: +48886680976

Deputy Editor: Mirosława Cieślicka, tel.: +48600945007

e-mail:cudaki@op.pl 
Bachinskaya N.V. Features of construction of structures in long-term training acrobatics at the modern stage ............3

Dzhym V. Yu. Peculiarities of perfection of training process of the qualified bodybuilder in the competitive period.......11

Kolokoltsev M.M., Cieslicka Miroslawa, Muszkieta Radoslaw. Optimization of physical training of students of high school with regard to quantitative features muscular components of their bodies.

Kondakov V.L., Kopeikina E.N., Balysheva N.V., Usatov A.N., Skrug D.A. Causes of declining interest of students to employment physical education and sports

Mikhnov A.P. Rationale set of indicators and prioritize relevant to assess competitive activity of hockey players of high qualification of different roles

Pryimakov A.A., Eider E., Omelchuk E.V. Stability of equilibrium in upright stance and voluntary motion control in athletes-shooters in the process of ready position and target shooting

Prosvirina L.N., Kolokoltsev M.M., Kolchanova M.A., Cieslicka Miroslawa, Stankiewicz Blazej. The characteristic of the engine qualities of the students of technical institute of III functional health group (special medical group)

Radzievskiy R.M., Plisko V.I. Law enforcers recognition level emerging threats based on physical appearance and behavior signs the enemy

Semanychyn T.M., Popel' S.L. Professional portrait of future instructors for physical education of preschool ........... 60

Shypulo I. P. Influence employment by improving aerobics on motor readiness of girls.....................................67

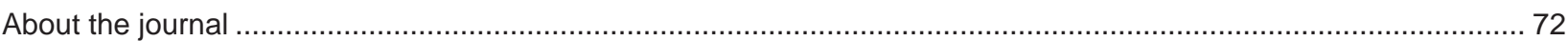

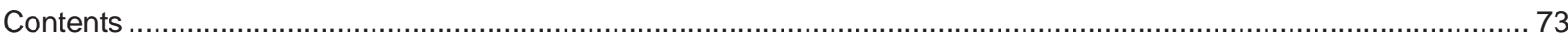

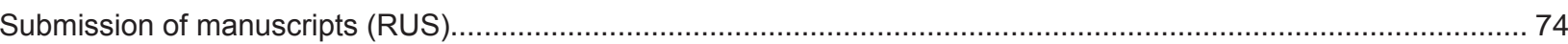

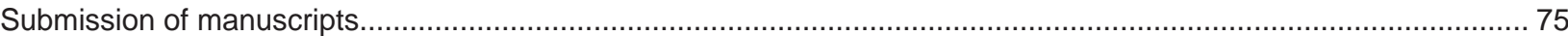




\title{
FEATURES OF CONSTRUCTION OF STRUCTURES IN LONG-TERM TRAINING ACROBATICS AT THE MODERN STAGE
}

Bachinskaya N.V.

Oles Honchar Dnipropetrovsk National University

\begin{abstract}
Annotation. Purpose: the basic directions of the structure of long-term training in sports acrobatics are ground. The objectives of the study was to determine the leading requirements and criteria, the main stages of a multi-year training in acrobatics. Material: analysis of special scientific and methodical literature, revealing the specific features of the construction of long-term training in sports and gymnastics, acrobatic rock ' $n$ ' roll, a number of other sports. Results: general structure, goals, objectives and provisions of the basic stages of a multi-year training in sports acrobatics. Singled leading indicators and criteria for each of the main stages of long-term sports training in acrobatics. Recommended duration of training sessions and key requirements for the preparation of acrobats. Conclusions: outlines the main requirements and benchmarks that can guide the trainer in a training and competitive activity when working with acrobats all age groups and different sports qualification.
\end{abstract}

Keywords: stages, structure, long-term training, acrobatics.

\section{Introduction}

Nowadays competition program of sport acrobatics has rather complicated and reached certain limit. Dynamics and virtuosity of exercises increased, new original elements and combinations appear (S.K. Malinovskiy, 2003, O.V. Shebaldina, 2004) [8, 15].

All changes, which have happened, require significant correction of certain theoretical and methodic approaches to process of acrobats' many-years' training Все те изменения, которые произошли, требуют значительной коррекции определенных теоретических и методических подходов к процессу многолетней подготовки акробатов (S.K. Malinovskiy, 2003; M.I. Pyliuk, [8, 10].

The purpose of many years' training of acrobats, like in any other kind of sports, is maintaining of optimal dynamics of physical qualities and functional potentials as well as achievement of maximal for every sportsman sport result (I.G. Gibaddulin, 2005; A.A. Ruziyev, 1999; T.M. Absaliamov, 1996) [1, 4, 13$]$.

Theoretical analysis and generalization of special literature showed that determination of perspective directions for perfection of many years training's structure in acrobatics have not nad proper scientific foundation and require additional work, considering the kind of sports.

Analyzing the above said we may state that on modern stage of sport acrobatics in Ukraine scientifically grounded conception of differentiated approach to training of acrobats, considering kinds of acrobatics, role in exercise, functional characteristics and gender distinctions of sportsmen.

Purpose, tasks of the work, material and methods

The purpose of the research is to give foundation for perspective directions of structure of many years' training in sport acrobatics.

The tasks of the research are to determine main indicators, criteria and main requirements of structure of many years' training in sport acrobatics.

The methods of the research: structural-functional analysis; synthesis; theoretical analysis of special scientific methodic literature and generalization; analogy and systemizing; pedagogic control over training and competition functioning of sportsmen; questioning, interviewing.

Results of the research

Analysis of a number of scientific publications, dissertations and programs for CJSS, SCJSS, devoted to acrobatics and other kinds of sports with complex coordination, permitted to form and mark out main directions of structure of many years' training in sport acrobatics (Ye.V. Bogatina, L.E. Pasmurova, "Crieria and orientations in sport acrobatics"/ Ye.V. Bogatina, L.E. Pasmurova, //Materials of V International students' electronic scientific conference "Students' scientific forum" URL: http://www.scienceforum.ru) [5-7, 9, 12, 16].

For realization of aims of many years' training it is necessary to fulfill the following conditions: training;

- Development of general plan of training and competition processes' construction on all stages of many years'

- Control of main parameters of training and competition loads, which are directed on achievement of the set aims, both intermediate and current;

- Planned and gradual increasing of scope of special physical training (SPT) in respect to general physical training (GPT);

- Compulsory consideration of age and gender characteristics;

- Development of acrobats' physical qualities in certain age periods. 
In process of many years' training its integral part is pedagogic control. It is realized for determination of dynamics of multi-functional development, level of general and special physical fitness, correspondence of planned physical loads to potentials of trainees and to temp of their biological growth.

Stage-by-stage control in sport acrobatics, as a rule, is conducted at the beginning and at the end of academic year. Its main tasks are: dynamic of physical condition's progressing as well as sportsmen's general and special physical fitness; determination of results' increment during year in comparison with standard requirements.

Current control is carried out at every training lesson as well as at the end of week cycle of training for analysis of organism's functional changes. Main tasks of it: determination of degree of tiredness and sportsman's recreation after training loads; degree of sportsman's readiness to taking of planned loads.

For direct registering of results of one training exercise, combination, composition and training in general operative control if fulfilled [5, 12, 21].

Sport training in acrobatics is a many years' annual process, which includes comprehensive development, training, and education of trainees.

Main forms of trainings in sport acrobatics are:

- Trainings-lessons of practical and theoretical character;

- Intermittent (after competition and transitive period) and summarizing (after academic year) testing;

- Regular participation in different competitions;

- Studying of video-records of qualified acrobats' trainings and competitions;

- Trainings as home by individual program;

- Regular trainings at camps;

- Trainings at health related sport camps;

- $\quad$ Studying of refereeing $[5,6,12]$.

On all stages of many ears' training in acrobatics main tasks are solved on the base of realization of curriculum, considering program schedule and standard requirements. Also mastering of training loads in compliance with curriculum is required.

Requirements and content of standards change depending of stage of training. Fulfillment of demanded criteria is compulsory for passing of trainees to next stage of many years' training.

Efficiency of many years' system of acrobats' training depends on a number of factors:

1. Age at beginning of sport acrobatic training. 2. Age at achievement of the highest results. 3. Consideration of regularities of formation of sportsmanship different sides in acrobats of different sex, formation of adaptation processes in main functions of organism. 4. Consideration of individual and gender distinctions of acrobats when planning training loads. 5. Means and methods of trainings, dynamic of training loads. 6. Peculiarities of building of training process's different structural formations.

In different kinds of sport acrobatics there are certain requirements to coach, videlicet:

- Presence of knowledge about methodic, practical and scientific achievements in acrobatics, about changes in classification and training programs;

- Knowledge about characteristics of motor, physical and functional development of trainees;

- Having techniques of sport exercises and means of teaching and sport training;

- умение анализировать и оценивать изменения в правилах соревнований. principles:

With orienting of trainees on such exercises as jumps on acrobatic track coach shall be guided by the following

- health condition and harmonious development of trainees;

- ability of trainees to effectively master acrobatic jumps;

- stability and reliability in fulfillment of exercises at trainings and competitions;

- high level of speed-power qualities, orientation in space and in time as well as integral sensor-motor coordination $[2,3]$.

In pair-group acrobatics trainees fulfill different functional roles, i.e. roles: upper, lower - in women, men and mixed pairs; upper, lower, central - in women groups; lower, first, central, second central, upper in men groups (four).

In every role acrobats need the following:

- prevailing development of strength, flexibility, quickness, endurance;

- balance in system of interacting bodies;

- space-time indicators of movements;

- reliable balance;

- sport techniques of supports, different stances (on one and two hands), throws, flights, catching, landing on hands and shoulders of partners;

- high level of choreographic fitness, musical abilities, artistry;

- presence of optimal weight-height indicators.

When completing of pair-group kinds of acrobatics coach shall compare biomechanically points of links (wristswrists), supporting points (shoulders-feet), working postures and consider sport techniques of such exercises with partners' combined actions [2, 3, 17]. 
Interconnections of kinds of training and main tasks are given in table 1 [5].

Table 1

Main tasks in kinds of sport acrobatics (generalized and processed data of L.V. Savonik, 2008)

\begin{tabular}{|c|c|}
\hline Kinds of training & Tasks (requirements) \\
\hline \multicolumn{2}{|l|}{ Physical } \\
\hline General physical & \multirow[t]{2}{*}{ Development of special physical qualities } \\
\hline Special physical & \\
\hline Special motion & Development of abilities, required for mastering acrobatic exercises \\
\hline \multicolumn{2}{|l|}{ Technical } \\
\hline With objects & Mastering of basic exercises \\
\hline Compositional & Training of competition programs \\
\hline Choreographic & Perfection of elements of classic and other dances \\
\hline \multicolumn{2}{|l|}{ Tactic } \\
\hline In individual kinds & Training of competition program Working out of tactic for competition \\
\hline In pair (group) exercises & $\begin{array}{l}\text { Logic disposition of acrobats and training of their interaction in pairs } \\
\text { (groups) }\end{array}$ \\
\hline In team & $\begin{array}{l}\text { Formation of team. Setting of team and personal tasks. The sequence of } \\
\text { performances at competitions }\end{array}$ \\
\hline \multicolumn{2}{|l|}{ Competition } \\
\hline All kinds of acrobatics & $\begin{array}{l}\text { Acquiring of experience of participation in competitions. Stability and } \\
\text { reliability of fulfillment of competition program }\end{array}$ \\
\hline
\end{tabular}

\section{Stage of initial training}

As analysis of special scientific methodic literature shows certain difficulties of selection in sport acrobatics are connected with sharp rejuvenation of sports. At initial stage mainly boy and girls of 6-8 years age are enrolled in sport acrobatic groups. This age period is favorable for mastering of new movements and the more of them will be mastered, the better, in future, difficult elements will be trained. This stage lasts $1-2$ years $[10,11,14]$.

At this stage, in acrobatic, main role is played by anthropometrical and morphological characteristics of trainees $[2,8,9,11,15]$.

When selecting children to acrobatic sport groups it is recommended by specialists to use a number of tests: balance, asymmetry of limbs' movements, latent period of motion response, quickness and frequency of movements, temp, posture. Sportsman's body height; size of foot, hand are important elements for choosing of sport acrobatic kind. Special accent is made on orientation of movements, which witnesses about physical condition and fitness, about condition of nervous system (strength, balance, mobility, dynamic) (Ye.V. Bogatina, L.E. Pasmurova, "Crieria and orientations in sport acrobatics"/ Ye.V. Bogatina, L.E. Pasmurova, //Materials of V International students' electronic scientific conference "Students' scientific forum" URL: http://www.scienceforum.ru); V.N. Boloban, 2008) [2, 3].

In connection with not stable in this age period attention it is recommended to use at trainings play form with methods of encouragement. Visual method of explanation is also widely used at trainings of such type.

On initial stage there is realized work, oriented on comprehensive physical progressing, teaching to principles of acrobatic techniques, fulfillment of tests for passing to next stage of training and cultivation of steady interest to sport acrobatic trainings.

Trainings are planned without usage of significant physical or psychological loads with accent on warming up exercises from different kinds of sports [7, 11, 14, 18-20, 22].

Main tasks of training at this stage are:

1. Selection of children for acrobatic training, considering morphological criteria and motor abilities. 2. Strengthening of health. 3. Harmonious physical development (removal of defects in physical condition). 4. Teaching to principles of acrobatic techniques' principles and to wide circle of motion skills. 5. Comprehensive development of physical qualities: flexibility, endurance, coordination, speed and power abilities. 6. Cultivation of moral-will qualities. 7. Formation of trainees' firm interest to systemic acrobatic trainings.

High level of trainings' effectiveness on this stage depends on a number of factors:

- Optimal age of starting of acrobatic trainings; 
- Selection of children with characteristics of composition, which correspond to requirements of sport acrobatic requirements;

- Complex evaluation of motion abilities' correspondence;

- Individual level of mastering of simple and complex elements.

Elements for accuracy and coordination are gradually introduced in trainings. Acrobats master space, time and power characteristics of movements, fulfilled with high amplitude, quickness and temp.

The basis of program includes GPT and SPT exercises, special movements training (SMT) and special technical training (STT). GPT include general developing exercises, run, jumps, climbing. SMT tasks include development of coordination abilities both of static and dynamic character.

Main tasks of STT at initial stage are mastering of basic elements of acrobatic, choreographic elements as well as exercises on battue. Evaluation of individual achievements reduces to fulfillment of control tests by trainees, i.e. tests, close to program of physical and technical trainings $[5,6,7,15]$.

Stage of preliminary basic training. To this stage trainees, who were trained at initial stage not less than 1-2 years, pass.

Optimal age for the beginning of basic stage of initial specialization in acrobatics is 8-10 years. Duration of the stage is, in average, $3-5$ years. Trainings take place in trainings groups $[5,6,9,12]$.

The necessary conditions are: fulfillment of special tests in general and special physical, technical trainings, which are determined by curriculum.

Main tasks of training are:

1. Strengthening of health.

2. Removal of defects in physical condition.

3. Perfection of level of general and specialized physical fitness.

4. Harmonious physical development.

5. Formation of steady interest to purposeful many-years' sport training.

6. Creation of firm motion potential for successful mastering of different motion skills.

7. Teaching to acrobatic techniques.

8. Preparation for tactical and psychological readiness.

9. Cultivation of moral-will qualities.

Stage of specialized training is especially important in formation of sportsmen. In this period main motion qualities are formed, great number of specific for acrobatic motion skills (elements and combinations) is mastered. Sportsmen acquire experience of participation in competitions. Basic elements are formed in basic combinations, which facilitate mastering of techniques in pair-group acrobatics. Some more difficult elements are mastered. For years of training at this stage the trainees are awarded with qualification sport grades.

Age of starting and finishing of this stage is influenced by individual temps of biological development.

Perfection of technique is based on material of the chosen kind of acrobatic. Comprehensive training with little scope of special exercises is characteristic for it. Such training results in formation of sportsmen's quick mastering of technique of the chosen kind of acrobatics.

Against the background of physical qualities' increment large loads shall not be planned at this stage.

Within this stage two periods are usually marked out: initial specialized training and profound specialized training. In period of initial specialized training acrobats master material of classification programs as well as perspective elements, links and combinations. In this period, as a rule, selection of acrobats in pairs or groups is conducted for more intensive deepened training.

In period of profound specialized training large scope of elements and combinations of technical training and SPT are criteria of acrobats' progress. Coaches conduct active pedagogic control for determination of promising sportsmen, who, in their age, go ahead of their peers. For starting of stage of profound specialization age of 10-12 year is considered to be optimal. This stage lasts 3-4 years.

Sportsmen are tested regularly by control tests for physical and technical fitness.

In this period sportsmen show increasing of physical fitness's level as well as sport results, considering individual features.

Main tasks of specialized profound training are: 1.Strengthening of health and comprehensive physical development. 2. Training and perfection of pair-group techniques. 3. Gradual leading of sportsmen to higher physical loads. 4. Dozed increase of training loads' intensity. 5. Mastering of complex elements and combinations, connected with combined rotations. 6. Moral will training, applied at competitions.

At this stage training means resemble competition exercises. We can observe increase of SPT and tactical training, means of power and special endurance.

There are certain factors, which restrict application of high physical loads at this stage: 1. Peculiarities of growing of junior sportsmen, i.e. functional specificities of organism. 2. Unevenness in morphological functional indicators and indicators of cardio-vascular system, body length and development of strength.

At stage of specialized training sportsmen, as a rule, master programs of candidate master of sports and even master of sports $[5,6,9]$. 
To stage of sport perfection usually sportsmen (as a rule 13-14 years old and older), who passed tests not less than for candidate master of sports, get. It is characterized by further deepening of specialized training, by mastering of standards for master of sports. Intensive increase of training loads coincides with active phase of acrobats' puberty. So individualized work is required; motor density of training increases. Coach work by individual plans in compliance with the set tasks.

\section{Main tasks of this stage:}

1. Planning of individual trainings (for every sportsman of acrobatic pair or group separately). 2. Perfection of technique of earlier mastered elements. 3. Mastering of elements of increased complexity.4.Successful performance of sportsmen by program of master of sports at competitions of different ranks (in particular at championships of Ukraine).5.Achievement of high and stable results and maintaining of results at high level for long time. 6. Fulfillment of tests for master of sports. 7. Making of competition program for participation in final of Ukrainian championships. 8. Selection and training of promising sportsmen for combined junior teams for participation in international competitions. $[5,6,9]$.

At this stage great physical loads are actively used; scope of fitness increases as well as integral and tactic fitness

Stage of highest sport achievements is regarded for every separate sportsman or pair (group) individually. For some sportsmen the highest sport result can be performance by program of master of sports, for other - medals at international competitions of different ranks.

One of the most important indicator of training process's effectiveness is results of acrobats' fitness: level of their technique in acrobatic elements and combinations; complexity of exercises (as per tables of complexity); reliability of fulfillment of competition compositions.

At this stage it is necessary to plan scope and intensity of loads, considering reliability and stability of mastering of competition program.

Coaches work individually with every sportsman, pair or group, who are in national combined team. Level of acrobats' sportsmanship is on high level. At this stage main criterion of progress is mastering of new competition programs, introduction of new elements in compliance with rising requirements.

At stage of finishing of sport career it is important to gradually reduce great training loads for [preservation of sportsmen's health. Sharp reduction of loads can negatively influence on health of trainees. In acrobatics, after sport career, advanced sportsmen, after special casting, have opportunity to work in different show programs, in particular in famous Canadian circus "Dusseli".

However, usually acrobats, at the end of acrobatic career, shall pass to 3-5 trainings a week mode (maintaining mode). Also, sportsmen can pass to other kinds of sports.

Duration of trainings and most important requirements to training of acrobats are briefly given in table 2.

Table 2

Structure of many years' training in sport acrobatics

\begin{tabular}{|c|c|c|c|}
\hline Training stages & Groups & Requirements & Q-ty of trainings \\
\hline Initial training & Initial training & $\begin{array}{l}\text { Fulfillment of tests for } \\
\text { mass grades }\end{array}$ & 2-3 times a week/ 1-2 hours \\
\hline Preliminary basic & Training & $\begin{array}{l}\text { III, II, I adult grade } \\
\text { CMS }\end{array}$ & 4-6 times a week/ 3-4 hours \\
\hline Specialized basic & Sport perfection & CMS & $\begin{array}{l}\text { 6-8 times (1-2 times a week, } \\
\text { double trainings })\end{array}$ \\
\hline $\begin{array}{l}\text { Preparation for highest } \\
\text { achievements }\end{array}$ & \multirow[t]{2}{*}{ Of highest sportsmanship } & \multirow[b]{4}{*}{$\begin{array}{l}\text { MS } \\
\text { IMS }\end{array}$} & \\
\hline $\begin{array}{l}\text { Maximal realization of } \\
\text { individual potentials }\end{array}$ & & & \\
\hline $\begin{array}{l}\text { Maintenance of highest } \\
\text { sportsmanship }\end{array}$ & \multirow[t]{2}{*}{ National combined teams } & & 6-8 times/ $3-4$ hours a day \\
\hline $\begin{array}{l}\text { Gradual reduction of } \\
\text { achievements }\end{array}$ & & & 3-5 times a week / 2-3 hours \\
\hline
\end{tabular}




\section{Conclusions:}

Analyzing of main tasks of all stages of many years' training we may conclude about the following:

1. At initial stage leading indicators are: efficiency of selection of trainees in acrobatic groups; preservation as much of contingent of trainees as possible; control of indicators of expelling of not promising sportsmen.

2. At stage of specialized training the criteria are: quantity and quality of mastered and steadily fulfilled elements of basic technical and physical fitness, acquiring of sport grades by trainees.

3. At stage of sport perfection leading requirements are: presence of free and final program, corresponding to model characteristics of promising acrobats, pairs and groups.

4. At stage of highest achievements main bench marks are: high sport result, membership in national combined team; continuous growth of competition programs' complexity and achievement of personal peak.

5. At stage of sport career's finalizing one can observe stabilizing of sport results, when complexity (competition difficulty) of exercises shows no dynamic. Results gradually reduce.

Some differences in age indicators of sportsmen's results are explained by specificities of early specialization; by coming of sportsmen from adjoining kinds of sports, in particular from sport gymnastic to acrobatics; by specificity of role (upper, lower, central), by different periods of puberty.

Further researches are planned in direction of studying of morphological functional distinctions of acrobats of different age and roles.

1. Absaliamov T.M. [Planning, control and management of training high-class athletes in cyclic sports]. Nauchnye trudy VNIIFK [Scientific papers VNIIFK], Moscow, VNIIFK, 1996, pp. 4-27. (In Russian)

2. Boloban V.N. Metodika otbora detej dlia zaniatij akrobatikoj. Sportivnaia akrobatika [Method of selecting children for training acrobatics. Sports acrobatics], Kiev, High School, 2008, pp. 18-32. (In Russian)

3. Boloban V. N. Obuchenie akrobaticheskim uprazhneniiam balansnogo tipa dvizhenij sistemy tel [Education acrobatic exercises balanced type motions of the system body]. Nauka a olimpijskom sporte, 2008, no.1, pp. 2432. (In Russian)

4. Gibaddulin I.G. Upravlenie trenirovochnym processom biatlonistov v sisteme mnogoletnej podgotovki. Dokt. Diss. [Management training process biathletes in the system long-term preparation, Dokt. Diss.], Moscow, 2005,309 p. (In Russian)

5. Savonik L.V. Dopolnitel'naia obrazovatel'naia uchebnaia programma «Sportivnaia akrobatika» [Additional educational training program "Sports acrobatics"], Murmansk, 2008, 39 p. (In Russian)

6. Berdinskikh S.Iu., Goncova E. Iu. Dopolnitel'naia obrazovatel'naia programma fizkul'turno-sportivnoj napravlennosti «Sportivnaia akrobatika» [Additional educational program of physical culture and sports orientation "sports acrobatics"], 2008, 96 p. (In Russian)

7. Kyzim P.N., Alabin V.G., Makurin Iu.K. Akrobaticheskij rok-n-roll [Acrobatic Rock and Roll]. Kharkov, Basis, 1999, 116 p. (In Russian)

8. Malinovskij S.K. Metodika sovershenstvovaniia special'noj fizicheskoj podgotovki akrobatov na etape nachal'noj sportivnoj specializacii [Technique of perfection of special physical preparation of acrobats on the stage of initial sports specialization]. Khabarovsk, 2003, 172 p. (In Russian)

9. Nesterova Tat'iana. Sovershenstvovanie sistemy mnogoletnej podgotovki sportsmenok v khudozhestvennoj gimnastike [Improving the system of long-term preparation of athletes in artistic gymnastics]. Nauka $v$ olimpijskom sporte, 2007, no.1 pp. 66-73. (In Russian)

10. Piliuk N.N. Postroenie i realizaciia sistemy sorevnovatel'noj deiatel'nosti akrobatov vysokoj kvalifikacii. Dokt. Diss. [Construction and implementation of a system of competitive activity of acrobats of high qualification. Dokt. Diss.], Moscow, 2003, pp. 4-10. (In Russian)

11. Platonov V., Sakhnovskij K., Ozimek M. Sovremennaia strategiia mnogoletnej sportivnoj podgotovki [Modern strategy of long-term sports preparation]. Nauka v olimpijskom sporte, 2004; (1); 3-13. (In Russian)

12. Kan V.Ia., Belgrad S.V., Ivanov V.A., Iasharov S.G., Levkov K.G. Programma sportivnoj podgotovki GBU "Sportivnaia shkola vol. 29 "Khamovniki» Moskomsporta po akrobaticheskomu rok-n-rollu [The program of sports training "Sports School 29" Acrobatic Rock and Roll]. Moscow, 2013, 59 p. (In Russian)

13. Ruziev A.A. Nauchno-metodicheskie osnovy mnogoletnej podgotovki kvalificirovannykh iunykh borcov. Dokt. Diss. [Scientific and methodological foundations of long-term preparation of qualified young wrestlers. Dokt. Diss.]. Moscow, 1999, 30 p. (In Russian)

14. Sakhnovskij K.P. Teoretiko-metodicheskie osnovy sistemy mnogoletnej sportivnoj podgotovki. Dokt. Diss. [Theoretical and methodological bases the system long-term sports preparation, Dokt. Diss.]. Kiev, 1997,318 p. (In Russian)

15. Shebaldina O.V. Komplektovanie sostavov zhenskikh akrobaticheskikh grupp na etape specializirovannoj podgotovki s uchetom pokazatelej teloslozheniia, motoriki i lichnostnykh osobennostej sportsmenok. Cand. Diss. [Recruitment compositions female acrobatic groups at the stage of specialized training based on indicators of body, motor skills and personality characteristics of female athletes. Cand. Diss.], Volgograd, 2004, 126 p. (In Russian) 
16. Batieieva N.P. Optimization of the training process with skilled athletes acrobatic rock and roll in the annual preparation of macrocycles based on model characteristics. Pedagogics, psychology, medical-biological problems of physical training and sports, 2014, no.8, pp. 3-8. http://dx.doi.org/10.6084/m9.figshare.1022947

17. Bołoban W., Wiśniowski W., Płaza M., Niźnikowska E., Niźnikowski T. The elements of sports orientation theory at the recrutrment for coordinationaly complex sports disciplines. Directions of development of scientific research in sports training. Częstochowa: Faculty of management Technical University of Częstochowa, 2004, pp. 9 - 12. (in Polish)

18. Zaporozhanov V.A., Kochanowicz K., Kochanowicz A. Improvement of comprehensive assessment of specially trained childhood and adolescence gymnasts. Pedagogics, psychology, medical-biological problems of physical training and sports, 2014, no.10, pp. 3-7. http://dx.doi.org/10.5281/zenodo.10482

19. Kozhanova O.S. Compatibility of sports-women at a selection in commands on group exercises of calisthenics taking into account their technical and special preparedness. Pedagogics, psychology, medical-biological problems of physical training and sports, 2013, no.2, pp. 34-37. http://dx.doi.org/10.6084/m9.figshare.639188

20. Lyulina N.V., Zakharova L.V., Vetrova I.V. Effect of complex acrobatic elements in the development of physical skills of preschool children. Physical education of students, 2013, no.4, pp. 59-62. http://dx.doi.org/10.6084/m9.figshare.662618

21. Omelyanenko V.I. Complex integrated method of improvement of sports ballroom dance perfomance. Physical education of students, 2014, no.6, pp. 49-53. http://dx.doi.org/10.15561/20755279.2014.0610

22. Soronovich I.M., Chaikovsky E.V., Pilevskaya V. Features of functional support of competitive activity in sports dance given the differences prepared by partners. Physical education of students, 2013, no.6, pp. 78-87. http://dx.doi.org/10.6084/m9.figshare.840556. 
Information about the author:

Bachynska N.V.: http://orcid.org/0000-0002-0448-9187; nat2nat@mail. ru; Oles Honchar Dnipropetrovsk National University; Gagarin Avenue, 72, Dnepropetrovsk, 49010, Ukraine.

Cite this article as: Bachinskaya N.V. Features of construction of structures in long-term training acrobatics at the modern stage. Physical education of students, 2015, no.1, pp. 3-10. http://dx.doi. org/10.15561/20755279.2015.0101

The electronic version of this article is the complete one and can be found online at: http://www.sportpedu.org.ua/html/arhive-e.html

This is an Open Access article distributed under the terms of the Creative Commons Attribution License, which permits unrestricted use, distribution, and reproduction in any medium, provided the original work is properly cited (http:// creativecommons.org/licenses/by/3.0/deed.en).

Received: 10.11.2014

Accepted: 10.12.2014; Published: 30.12.2014 


\title{
PECULIARITIES OF PERFECTION OF TRAINING PROCESS OF THE QUALIFIED BODYBUILDER IN THE COMPETITIVE PERIOD
}

\author{
Dzhym V. Yu.
}

Kharkov State Academy of Physical Culture

\begin{abstract}
Annotation. Purpose: study methods of improving the training process of skilled bodybuilders in the competitive period. Material: The study involved 18 athletes aged 18-25 years old. The experiment was conducted for 8 weeks. Used two variants of training techniques: large percentage weights; with smooth dynamics with emphasis on static load muscles. Efficacy was evaluated using the preparation method of expert evaluations. The method involved the use of information on the implementation of directives coach dynamics of power and endurance performance, subjective indicators (health, mood, desire to train). Results: comparative characteristic of the most commonly used methods of training process in bodybuilding. Developed and justified best practices, depending on the initial form of the athlete at the beginning of the competition period of training. Shows the dependence of changes in body weight of the athlete training. Conclusions: the proposed best practices, depending on the microcycle training in the competitive period (precompetitive and competitive mesocycles).
\end{abstract}

Keywords: training, bodybuilding, qualified, optimal, method, microcycle.

\section{Introduction}

Since $90-$ s, in Ukraine new for the country kinds of sports have been becoming more and more popular. In weight lifting they were, first of all, power-lifting and bodybuilding. Considering the fact that domestic theoretical and practical trainings base for such kinds of sports is only on stage of creation, the topic of this article is rather urgent for domestic sports.

One of most important problems of bodybuilders' training for competitions in Ukraine is adaptation of foreign classic methodic to domestic reality and, thus to achievement of high results.

Training system of qualified body builders is based on rationally built training process in combination with diet as factor, ensuring required material for decreasing of fat layer and growing of muscular mass.

That is why there was worked out and scientifically grounded methodic of training process of qualified bodybuilders in competition period of year training cycle $[1 ; 2]$.

In domestic sports there is a little of scientifically grounded training methodic for qualified bodybuilders in preparatory period of special-training stage. Thus, coaches and sportsmen shall acquire practical experience by the method of trial and error $[6 ; 9]$.

In bodybuilding competition process lasts 8 weeks. In this period qualified sportsmen of different age groups and categories try as much as possible to reduce under-skin fat layer and water with the help of trainings with optimal weights. At the end of every micro-cycle form of sportsman is estimated by coaches and anthropometric data are measured, corrections in training process and plan of diet are made $[3 ; 15-18]$.

This problem was dealt with by such outstanding domestic specialists in physical culture as V.M. Platonov, L.S. Dvorkin, A.I. Stetsenko, B.I. Sheyko, V.G. Oleshko, A.I. Kamayev, D.A. Beskorovayniy, V.V. Usichenko [4-10]. Their researches based on experience of such foreign specialists as Joe Wider, Ben Wider, E. Connors, T. Kimber, M. Mc Kormic [12-14].

The present scientific research has been fulfilled as per topic of combined plan of scientific-research works in sphere of physical culture and sports for на 2011-2015. Topic 3.7 "Methodological and organizational methodic principles of determination of individual norm of human physical condition" (state registration No. 0111U000192).

\section{Purpose, tasks of the work, material and methods}

The purpose of the research: To give foundation to methodic of improvement of qualified bodybuilders' training process in competition period.

The methods of the research: Theoretical method and generalization of literature, pedagogic observation, pedagogic experiment, method of mathematical statistics.

Materials of the research: members of combined team of Kharkovska region participated in the experiment. They were 18 bodybuilder: 4 masters of sport, 14 - candidate masters of sports of 18-25 years old; mean body mass was $85 \pm 2-100 \pm 2 \mathrm{~kg}$. The participants were distributed by sport qualification into two groups": experimental (EG) and control group (CG). Control group sportsmen trained 5 times a week; experimental group trained 5-6 times a week.

\section{Results of the research}

Usage of training process of qualified bodybuilders conditioned application of two training methodic, which differed by load and scope of trainings exercises, rest periods and other components. Evaluation was conducted with the help of training diaries, in which quantity and scope of training work was noted.

Training effectiveness was evaluated with method of experts' evaluation, which envisaged application of information about fulfillment of coach's instructions, dynamic of power indicators and endurance as well as subjective qualities (self-feeling, mood, wish to train and so on).

\footnotetext{
(c) Dzhym V. Yu.

2015 http://dx.doi.org/10.15561/20755279.2015.0102
} 
Control group sportsmen trained during 8 weeks with great percentage loads; experimental group sportsmen trained with smooth dynamic with static exercises prevailing (see table 1,2) Before experiment we fulfilled testing measuring of sportsmen's masses, anthropological measurements for determination of better results in indicators' increment. For weighing, we used mass analyze (scales TANITA BC-545, made in Japan) and centimeter measuring tape (see table 3, 4).

Distinction of preparatory period from competition one is in more smooth transition from one training microcycle to other, as well as in increasing of quantity of repetitions and trials for better separation and definitions of muscles (see table 1). Increasing of trainings' quantity, shortening of breaks between trainings days is very important in preparation at this stage. Also, as it can be seen in table 1, intensity is important; time of exercises' fulfillment significantly reduced both in positive and negative phases and pauses between repetitions reduced - in preparation cycle up to $0.5 \mathrm{sec}$. and in competition micro-cycle there was no rest between repetitions at all.

Specificity of this stage is also little percent application of small weights, which was in first pre-competition meso-cycle in EG - 50\%, and in CG 60 - 80\%, in second competition meso-cycle - 70 - 30\% in EG and $80-70 \%$ in $\mathrm{CG}$, thus in EG greater attention was paid to work with muscles, but not to gaining mass that was most important at this stage.

Table 1

Content of training program depending on mass of load in competition period of qualified bodybuilders (experimental and control groups)

\begin{tabular}{|c|c|c|c|c|}
\hline \multirow{3}{*}{$\begin{array}{l}\text { Indicators of training loads and } \\
\text { classification of muscular groups }\end{array}$} & \multicolumn{4}{|c|}{ Meso-cycles } \\
\hline & \multicolumn{2}{|c|}{ Pre-competition } & \multicolumn{2}{|c|}{ Competition } \\
\hline & CG & EG & CG & EG \\
\hline Range of load in percent from maximum & $60-80$ & $30-60$ & $80-70$ & $70-30$ \\
\hline Quantity of training days & 5 & 6 & 6 & 6 \\
\hline Quantity of repetitions & $10-12$ & $12-18$ & $12-15$ & $15-25$ \\
\hline Quantity of trials & $5-6$ & $5-6$ & $5-6$ & $6-8$ \\
\hline \multicolumn{5}{|c|}{ Time of exercise's fulfillment, sec. } \\
\hline $\begin{array}{l}\text { POSITIVE PHASE (MOVEMENT } \\
\text { UPWARD) }\end{array}$ & 1 & 0,5 & 1 & 0,5 \\
\hline Negative phase (movement downward) & 1,2 & 0,5 & 1 & 0,5 \\
\hline Pauses between repetitions, sec. & 0,8 & & 0,5 & - \\
\hline \multicolumn{5}{|c|}{ Rest between trials, min. } \\
\hline In basic exercises & $2-2,5$ & $1-1,2$ & 1,5 & 1 \\
\hline In shaping exercises & 1,5 & 50 & 1 & $30-50$ \\
\hline \multicolumn{5}{|c|}{ Rest time between loading of muscular groups (days) } \\
\hline Hips & 5 & 3 & 4 & 3 \\
\hline Back & 5 & $3-5$ & 4 & $3-5$ \\
\hline Breast & 3 & 4 & 3 & 4 \\
\hline Deltoid muscle & 4 & 5 & 4 & 5 \\
\hline Biceps muscle & 2 & 3 & 2 & 3 \\
\hline TRICEPS MUSCLE & 3 & 4 & 3 & 4 \\
\hline Forearm & 6 & 5 & 6 & 5 \\
\hline Triceps of shin & 6 & 3 & 6 & 3 \\
\hline Oblique and direct abdominal muscles & 3 & 1 & 3 & 1 \\
\hline Neck & 0 & 2 & 0 & 2 \\
\hline
\end{tabular}

The data, presented in table 2, witness that experimental group sportsmen trained with moderate weights comparing with maximal; control group trained with little quantity of repetitions but with heavy weights that is not recommended in pre-competition period, because in this period sportsmen, preparing for competitions, reduce quantity of carbon hydrates. For example, in competition period great attention is paid to muscles of hip and shin - quantity of weight bar's lifting (QWBL) is 1.797 in EG per two micro-cycles, in CG - 1.566 mainly at the account of muscles of arms, breast and back, which are practically same (650- 732 lifting of 62.500-96.400kg weight). But in this period main role is played by shaping exercises, which were different by QWBL and by calculated kilograms; that is why maximally great number of weight bar lifting was at the account of oblique and direct abdominal muscles and was in EG 9.220 QWBL and in CG 8.850 QWBL. Total scope of QWBL in basic exercises was in EG 5.254 and in CG 4.457, while in shaping exercises in EG it was 17.900 and in CG - 16.451 QWBL. Thus, CG used more powerful program of training and little quantity of QWBL with big weights. EG used more static program of training and used higher quantity of QWBL that is why scope of kilograms was higher. 
Table 2

Total scope of training work, fulfilled by qualified bodybuilders of control and experimental groups in competition period

\begin{tabular}{|l|l|l|l|l|}
\hline \multirow{2}{*}{ Group s of muscles } & \multicolumn{1}{c}{ Scope of QWBL } & \multicolumn{2}{l|}{ Scope, thousands of kg. } \\
\cline { 2 - 5 } & CG & EG & CG & EG \\
\hline \multicolumn{2}{|c|}{ Basic exercise for: } \\
\hline Muscles of upper girdle & 550.0 & 650.0 & 59.200 & 62.500 \\
\hline Muscles of arms & 780.0 & 900.0 & 76.550 & 85.660 \\
\hline Muscles of breast & 582.0 & 732.0 & 88.250 & 96.400 \\
\hline Muscles of back & 979.0 & 1.175 & 166.100 & 182.090 \\
\hline Muscles of hips and shins & 1.566 & 1.797 & 240.562 & 305.695 \\
\hline Total & 4.457 & 5.254 & 630.662 & 732.345 \\
\hline \multicolumn{5}{|l|}{} \\
\hline Muscles of upper girdle & 1.550 & 1.632 & 110.340 & 139.520 \\
\hline Muscles of arms & 820.0 & 965.0 & 58.250 & 65.380 \\
\hline Muscles of breast & 520.0 & 630.0 & 63.670 & 65.380 \\
\hline Muscles of back & 1.035 & 1.368 & 105.350 & 118.080 \\
\hline Muscles of hips and shins & 3.676 & 4.105 & 505.250 & 537.740 \\
\hline Oblique and direct abdominal muscles & 8.850 & 9.220 & - & - \\
\hline Total & 16.451 & 17.900 & 842.860 & 926.100 \\
\hline
\end{tabular}

Notes: QWBL - quantity of lifting of weight bar

Total scope of calculated kilograms in basic exercises is 732.345 in EG and 630.662 in CG; in shaping exercises total scope is $926.100 \mathrm{~kg}$ in EG and 842.860 in CG. We can make general conclusion that experimental group sportsmen trained at this stage with moderate scope of kilograms and paid more attention to abdominal muscles and muscles of legs as far as after preparatory period (28 micro-cycles) there was significant increment of subcutaneous fat layer on abdomen and hips. In their turn, CG sportsmen paid more attention to basic exercises and power indicators than to shaping exercises.

Before experiment we fulfilled anthropological measurements. As we can see in table 3, variation coefficients of all main anthropological indicators, separately for control and experimental groups, practically did not exceed general initial level.

Anthropometrical examination was fulfilled before beginning and at the end of competition period,(see tables $3,4)$.

Table 3

Mean anthropological indicators of qualified bodybuilders of control and experimental groups at the beginning of competition period $\left(n_{1}=n_{2}=9\right)$

\begin{tabular}{|l|c|c|c|c|c|c|}
\hline \multirow{2}{*}{ Indicator } & \multicolumn{2}{|c|}{ CG } & EG & \multirow{2}{*}{$P$} \\
\cline { 2 - 7 } & $\bar{X}_{1} \pm m_{1}$ & $V, \%$ & $\bar{X}_{2} \pm m_{2}$ & $V, \%$ & & \\
\hline Body mass, kg & $94.17 \pm 3.74$ & 11.91 & $94.00 \pm 4.17$ & 13.30 & 0.02 & $>0.05$ \\
\hline Circumference of neck, cm & $42.50 \pm 1.36$ & 9.62 & $42.78 \pm 1.29$ & 9.03 & 0.12 & $>0.05$ \\
\hline Circumference of breast (inhale), cm & $113.83 \pm 1.88$ & 4.95 & $117.88 \pm 2.60$ & 6.62 & 1.03 & $>0.05$ \\
\hline Circumference of breast (exhale), cm & $105.33 \pm 1.91$ & 5.43 & $107.22 \pm 2.26$ & 6.32 & 0.52 & $>0.05$ \\
\hline Circumference of biceps, cm & $43.00 \pm 1.91$ & 13.32 & $44.45 \pm 1.59$ & 10.72 & 0.48 & $>0.05$ \\
\hline Circumference of waist, cm & $80.33 \pm 2.34$ & 8.76 & $81.95 \pm 2.52$ & 9.22 & 0.38 & $>0.05$ \\
\hline Circumference of hip, cm & $79.00 \pm 1.74$ & 6.60 & $79.72 \pm 1.84$ & 6.93 & 0.23 & $>0.05$ \\
\hline Circumference of shin, cm & $40.33 \pm 1.31$ & 9.75 & $41.12 \pm 1.41$ & 10.32 & 0.33 & $>0.05$ \\
\hline Circumference of forearm, cm & $37.33 \pm 1.32$ & 10.64 & $39.17 \pm 1.85$ & 14.21 & 0.66 & $>0.05$ \\
\hline Length of body, cm & $168.00 \pm 1.40$ & 2.50 & $170.50 \pm 2.25$ & 3.96 & 0.77 & $>0.05$ \\
\hline Length of torso, cm & $77.83 \pm 0.65$ & 2.49 & $78.00 \pm 0.63$ & 2.43 & 0.15 & $>0.05$ \\
\hline Length of lower limb, cm & $90.17 \pm 0.88$ & 2.93 & $90.33 \pm 0.91$ & 3.02 & 0.11 & $>0.05$ \\
\hline Length of upper limb, cm & $83.67 \pm 1.22$ & 4.39 & $83.67 \pm 1.22$ & 4.39 & 0.001 & $>0.05$ \\
\hline
\end{tabular}

So, at the beginning of competition period differences are insignificant: in body mass (control group $-94.17 \mathrm{~kg}$ and experimental group - $94.00 \mathrm{~kg} ; \mathrm{P}>0, .05)$; circumference of waist (accordingly $-80.33 \mathrm{~cm}$ and $81.95 \mathrm{~cm}$; $\mathrm{P}>0.05$ ); circumference of hip (accordingly $-79.00 \mathrm{~cm}, 79.72 \mathrm{~cm} ; \mathrm{P}>0.05$ ); circumference of neck (accordingly $-42.50 \mathrm{~cm}$, $42.78 \mathrm{~cm} ; \mathrm{P}>0.05)$; circumference of breast at inhale (accordingly $-113.83 \mathrm{~cm}, 117.88 \mathrm{~cm} ; \mathrm{P}>0.05)$ and circumference of breast at exhale (accordingly $-105.33 \mathrm{~cm}, 107.72 \mathrm{~cm} ; \mathrm{P}>0.05$ ) and shin (accordingly $-40.33 \mathrm{~cm}$, $41.12 \mathrm{~cm} ; \mathrm{P}>0.05)$. 
Variation coefficients of all main anthropological indicators, separately for control and experimental groups, practically did not exceed general initial level. For example for control group it was $\mathrm{V}=11.91 \%$, and for experimental group - $\mathrm{V}=13.30 \%$. Accordingly for control and experimental group variation coefficients were: circumference of hips $\mathrm{V}=6.60 \%, \mathrm{~V}=6,93 \%$; circumference of waist $-\mathrm{V}=8.76 \%, \mathrm{~V}=9.22 \%$; circumference of biceps $-\mathrm{V}=13.32 \%, \mathrm{~V}=$ $10.72 \%$.

Table 4

Mean indicators of reduction of qualified bodybuilders' anthropological data of control and experimental groups at the end of competition period $\left(n_{1}=n_{2}=9\right)$

\begin{tabular}{|l|c|c|c|c|}
\hline \multicolumn{1}{|c|}{ Indicator } & $\mathrm{CG}$ & $\mathrm{EG}$ & \multirow{2}{*}{$\boldsymbol{t}$} & $\boldsymbol{P}$ \\
\cline { 2 - 5 } & $\overline{\mathbf{X}}_{\mathbf{1}} \pm \mathbf{m}_{\mathbf{1}}$ & $\overline{\mathbf{X}}_{\mathbf{2}} \pm \mathbf{m}_{\mathbf{2}}$ & & \\
\hline Body mass, $\mathrm{kg}$ & $11.7 \pm 1.0$ & $5.0 \pm 0.3$ & 5.42 & $<0.01$ \\
\hline Circumference of neck, cm & $4.0 \pm 0.4$ & $2.0 \pm 0.2$ & 3.87 & $<0.01$ \\
\hline Circumference of breast (inhale), cm & $5.2 \pm 0.4$ & $2.2 \pm 0.3$ & 4.81 & $<0.01$ \\
\hline Circumference of breast (exhale), cm & $5.2 \pm 0.4$ & $2.5 \pm 0.2$ & 5.05 & $<0.01$ \\
\hline Circumference of biceps, cm & $3.3 \pm 0.5$ & $1.8 \pm 0.3$ & 2.18 & $>0.05$ \\
\hline Circumference of waist, cm & $4.8 \pm 0.4$ & $2.7 \pm 0.2$ & 4.15 & $<0.01$ \\
\hline Circumference of hip, cm & $4.3 \pm 0.3$ & $2.5 \pm 0.2$ & 3.84 & $<0.01$ \\
\hline Circumference of shin, cm & $2.5 \pm 0.2$ & $1.5 \pm 0.2$ & 3.16 & $<0.05$ \\
\hline Circumference of forearm, cm & $0.2 \pm 0.1$ & $0.8 \pm 0.3$ & 1.60 & $>0.05$ \\
\hline Length of body, cm & $168.0 \pm 1.4$ & $170.5 \pm 1.4$ & 0.77 & $>0.05$ \\
\hline Length of torso, cm & $77.8 \pm 0.6$ & $78.0 \pm 0.6$ & 0.15 & $>0.05$ \\
\hline Length of lower limb, cm & $90.2 \pm 0.9$ & $90.3 \pm 0.9$ & 0.10 & $>0.05$ \\
\hline Length of upper limb, cm & $83.7 \pm 1.2$ & $83.6 \pm 1.2$ & 0.0001 & $>0.05$ \\
\hline
\end{tabular}

For example, at the end of competition period probability of differences was proved: in body mass (control group - $11.7 \mathrm{~kg}$ and experimental group $-5.0 \mathrm{~kg}$; $\mathrm{P}<0.01$ ); circumference of waist (accordingly $-4.8 \mathrm{~cm}, 2.7 \mathrm{~cm} ; \mathrm{P}$ $<0.01$ ); circumference of hip (accordingly $-2.5 \mathrm{~cm}, 1.5 \mathrm{~cm} ; \mathrm{P}<0.05$ ); circumference of neck (accordingly $-4.0 \mathrm{~cm}, 2.0$ $\mathrm{cm} ; \mathrm{P}<0.01$ ); circumference of breast ant inhale (accordingly $-5.2 \mathrm{~cm}, 2.2 \mathrm{~cm} ; \mathrm{P}<0.01$ ) and exhale (accordingly -2.5 $\mathrm{cm}, 1.5 \mathrm{~cm} ; \mathrm{P}<0.05)$.

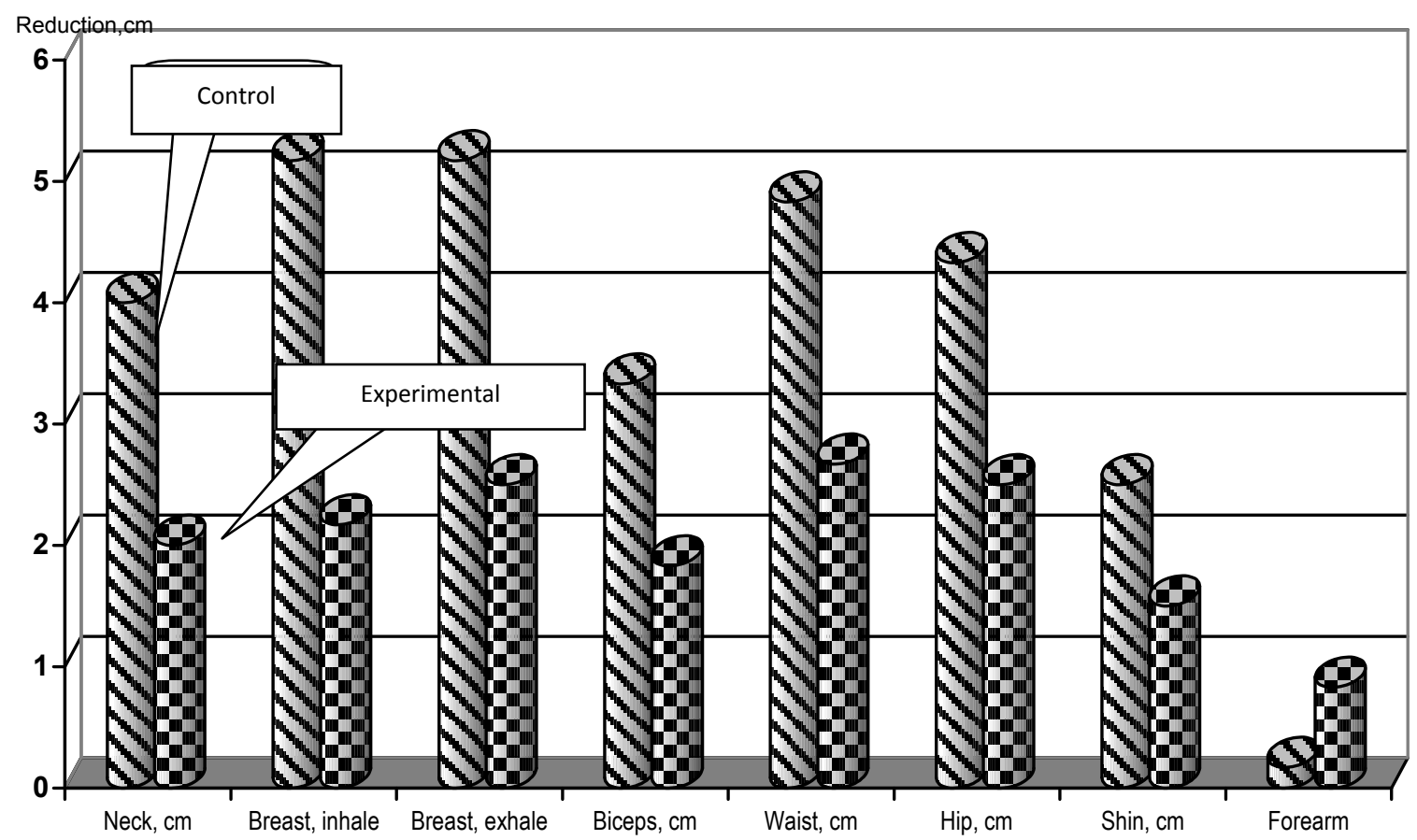

Fig.1. Comparative diagram of increment of anthropometric data of qualified bodybuilders (control and experimental groups) on competition period

\section{Conclusions:}

Thus, perfection of training process for qualified bodybuilders, permits to consider that in EG effect was more expressed and level of fitness can be estimated as optimal. Dynamic of load in this group significantly reduces probability of functional disorders (over-tension, over-training, traumas); it permits to achieve required level of sport fitness without over-tension of adaptation-compensatory mechanisms. In respect to construction of training process, in 
EG methodic of training more facilitates fulfillment of the set task - preservation of muscular mass during burning of subcutaneous fat and water; indicators of body mass are $(\mathrm{t}=5.42 ; \mathrm{p}<0.001)$, Circumference of breast (inhale) $\mathrm{t}=4.81$; $\mathrm{p}<0.001)$ and at exhale $(\mathrm{t}=5.05 ; \mathrm{p}<0.001)$, waist $(\mathrm{t}=4.15 ; \mathrm{p}<0.001)$, hip $(\mathrm{t}=3.84 ; \mathrm{P}<0.01)$ and shin $(\mathrm{t}=3.16 ; \mathrm{p}$ $<0.05)$.

Improved methodic of training for qualified bodybuilders in competition period can be recommended for training of sportsmen with observation of sport and medical requirements, for ensuring of effective and qualitative recreation in transitive period.

Further researches shall include working out and foundation of training process of qualified bodybuilders in transitive period.

\section{References:}

1. Blauberg I. V., Iudin E. G. Stanovlenie i sushchnost' sistemnogo podkhoda [Formtion and essence of system approach]. Moscow, Science, 1973, 272 p. (in Russian)

2. Grishina Iu. I. Osnovy silovoj podgotovki [Basic strength training]. Rostov on Don, Phoenix, 2011 , 280 p. (in Russian)

3. Dzhim V. Iu. Osoblivosti kharchuvannia bodibilderiv u pidgotovchomu periodi trenuvan' [Features nutrition bodybuilders in the preparatory period of training] Slobozhans'kij naukovo-sportivnij visnik. 2013, no. 4(37), pp. 15-19. (in Ukrainian)

4. Dvorkin L. S. Vazhka atletika $i$ vik [Weightlifting and age]. Sverdlovsk, Ural University Publ., 1989,2000 p. (in Ukrainian)

5. Shejko B. I. Pauerlifting [Powerlifting]. Moscow, Sports service, 2003, 532 p. (in Russian)

6. Oleshko V. G. Silovye vidy sporta [Strength kinds of sports]. Kiev, Olympic Literature, 1999, 287 p. (in Russian)

7. Platonov V.N. Sistema podgotovki sportsmenov v olimpijskom sporte [The system of preparation of sportsmen in Olympic sport], Kiev, Olympic Literature, 2004, 808 p. (in Russian)

8. Stecenko A. I. Pauerlifting [Powerlifting]. Cherkasy, NDITEHIMu, 2008, 459 p. (in Ukrainian)

9. Kamaiev O. I., Bezkorovajnij D. O. Rozvitok silovikh zdibnostej 13-15-richnikh iunakiv u silovikh vidakh sportu [Development of power abilities of 13-15-year-old boys in the power types of sport]. Kharkov, KSAPC, 2014, 106 p. (in Ukrainian)

10. Usychenko V. V. Periodizaciia godichnogo cikla podgotovki sportsmenov specializiruiushchikhsia v bodibildinge [Periodization of the annual cycle of training athletes specializing in bodybuilding]. Pedagogics, psychology, medical-biological problems of physical training and sports. 2006, no.7, pp. 123-125. (in Russian).

11. Zverev V. D. Planirovanie trenirovochnoj nagruzki v podgotovitel'nom periode v bodibildinge s uchetom silovoj napravlennosti [Planning the training load in the preparatory period in bodybuilding, taking into account power orientation]. Sankt Petersburg, SPbGAFK P.F. Lesgaft, 200355 p. (in Russian)

12. Dzho Uajder. Sistema stroitel'stva tela [The system of construction of the body]. Moscow, Physical Culture and Sport, 1991, 112 p. (in Russian)

13. Vejder B., Vejder D. Klassicheskij bodibilding [Classic bodybuilding]. Moscow, Exmo, 2003, 432 p. (in Russian)

14. Konnors E., Grimkovski P. , Kimber T. , Mak-Kormik M. Bodibilding [Bodibilding]. Moscow, FAIR PRESS, 2000, 174 p. (in Russian)

15. Djim V.Y., Comparative analysis of exercise equipment jerk in weightlifting and weight sport. Pedagogics, psychology, medical-biological problems of physical training and sports, 2013, no.11, pp. 10-16. http://dx.doi.org/10.6084/m9.figshare.815868

16. Kleiner S. M., Bazzarre T. L., Ainsworth B. E. Nutrional status of nationally ranked elite bodybuilders. International Journal of Sport Nutrition. 1994, no.4, pp. 54-69.

17. Cornelius A. E., Brewer B. W., Van Raalte J.L. Applications of multilevel modeling in sport injury rehabilitation research. International Journal of Sport and Exercise Psychology.2007, vol.5, no.4, pp. $387-405$. http://dx.doi.org/10.1080/1612197X.2007.9671843.

18. Visek A. J., Watson J. C., Hurst J. R., Maxwell J. P., Harris B. S. Athletic identity and aggressiveness: A crosscultural analysis of the athletic identity maintenance model. International Journal of Sport and Exercise Psychology. 2010, vol.8, no.2, pp. 99-116. http://dx.doi.org/10.1080/1612 197X.2010.9671936. 
Information about the author:

Dzhym V.Yu.: http://orcid.org/0000-0002-4869-4844; djimvictor@mail. ru; Kharkov State Academy of Physical Culture; Klochkovskaya str. 99 Kharkov, 61022, Ukraine.

Cite this article as: Dzhym V. Yu. Peculiarities of perfection of training process of the qualified bodybuilder in the competitive period. Physical education of students, 2015, no.1, pp. 11-16. http:// dx.doi.org/10.15561/20755279.2015.0102

The electronic version of this article is the complete one and can be found online at: http://www.sportpedu.org.ua/html/arhive-e.html

This is an Open Access article distributed under the terms of the Creative Commons Attribution License, which permits unrestricted use, distribution, and reproduction in any medium, provided the original work is properly cited (http:// creativecommons.org/licenses/by/3.0/deed.en).

Received: 20.11 .2014

Accepted: 10.12.2014; Published: 30.12.2014 


\section{OPTIMIZATION OF PHYSICAL TRAINING OF STUDENTS OF HIGH SCHOOL WITH REGARD TO QUANTITATIVE FEATURES MUSCULAR COMPONENTS OF THEIR BODIES}

Kolokoltsev M.M. ${ }^{1}$, Cieslicka Miroslawa ${ }^{2}$, Muszkieta Radoslaw ${ }^{2}$

National Research Irkutsk State Technical University, Russia ${ }^{1}$

Kazimierz Wielki University in Bydgoszcz, Poland ${ }^{2}$

Annotation. Purpose: to provide a quantitative description of the muscle component of students ${ }^{\text {ee }}$ body with regard to their motor characteristics to improve training in the discipline "Physical Education". Material: a study of muscular component of the body in 1937 students aged 17-20 years old of age living in the Baikal region. Motor quality students were evaluated by tests. Problem analysis was conducted based on the data of Polish authors. Results: the dependence of the amount of content in muscle mass in the body of the frequency of physical training in high school. Also found significantly higher levels of performance in motor tests in the group of students with a high level of expression of muscle mass. Conclusions: the studies have shown a direct relationship content of lean body mass of locomotor activity. Set better indicator values in tests of physical fitness with a high content of muscle tissue. Lack of exercise training on older years is recommended to compensate for self-manage motor activities.

Keywords: students, muscle mass, physical, preparedness, physical culture.

\section{Introduction}

Among environmental factors, which influence on formation of bodyes componential composition, practicing of physical culture and sports are rather important. In this connection significance of studying of body"s componential composition, considering motion characteristics in complex studying of organism, is scientifically grounded and demanded [8].

It has been proved that componential composition of body reflects level of physical condition. At the same time it is a criterion of health and motion functioning $[2,5]$.

Thus, modern ideas, theories and methodic of physical education and medicine are single in opinion that it is necessary to consider individual specificities of person's development and condition [1, 11, 13, 15, 20]. Seeking of methods of physical load's individualization has been carrying out for long time, but mainly on the base of personification of methodic, pointed at achievement of mean-statistical standards of motion functioning. However, such approach weakens individual abilities of a person, because it requires their uniformity [10]. In opinion of V.V. Zaytseva [4], it is possible to significantly increase effectiveness of trainings and strengthen motivation for practicing of physical culture and sports with the help of methods and means, pointed at achievement of individual standards by every person on the base of his (her) constitutional-typological belonging. With it, level of indicators of body composition and their dynamic completely depends on structure of trainings, scope and intensity of physical loads [5, 14, 16-19].

Recent years, in Irkutskaya region there have been conducting researches on evaluation and analysis of only type-morphological status of 17-20 years old girls [6]. That is why it is important to fulfill additional researches for determination of composition and characteristic of interconnection between indicators of physical fitness and quantity of muscular component in girl students ${ }^{\text {ec }}$ bodies (girl student of technical HEE in Baykal district).

\section{Purpose, tasks of the work, material and methods}

The purpose of the research is to provide quantitative characteristics of girl students "e muscular component, (Baykal district) considering their motion abilities, for perfection of "Physical culture" lessons.

The methods and organization of the research. We have examinedMетоды и организация исследования. 1937 girl students of National research Irkutsk state technical university. Mean age of the girls was 18.5 years and varied from 17 to 20 years. In our work we used standard anthropometrical methodic of V.V. Bunak (1941), considering requirements of anthropological scientific research institute of MSU (1982), and with the help of standard devices. Our measurements were carried out in medical office of HEE, considering volunteer character of participation, considering rights and freedom of a personality, guaranteed by $\mathrm{Cl} .21$ and 22 of Constitution of RF. The research was fulfilled in compliance with principles of Helsinki Declaration (2008). All tested were informed about character and purposes of the research and gave written permission for participation in it.

From all, mentioned in literature methodic of determination of body“s component composition we chose and used methodic of R.N. Dorokhov and V.G. Petrukhin (1989) [3], which was tested in clinical and pedagogic practice. This scheme is highly informative and has significant advantages in comparison with subjective schemes of diagnostic; besides, it is the most convenient for application in evaluation of morphological characteristics. Componential level of variation of properties (CLP) was determined by content of fat (FM), muscular (MM) and bone (BM) masses. Evaluation of MM was fulfilled by summing of four circumferences (shoulder and hip (upper and lower) and by deduction of FM, multiplied by 3.13 from this sum:

$$
\mathrm{MM}=(\mathrm{CUS}+\mathrm{CLS}+\mathrm{CUH}+\mathrm{CLH})-\mathrm{FM} \times 3.14 .
$$

\footnotetext{
(c) Kolokoltsev M.M., Cieslicka Miroslawa, Muszkieta Radoslaw, 2015

http://dx.doi.org/10.15561/20755279.2015.0103
} 
Content of body's muscular component (in \%) was divided by 5 sigma classes: $\mathrm{M} \pm 0.67 \mathrm{~s}-\langle$ mean»value of indicators for sample. If they are in interval from $\pm 0.67 \mathrm{~s}$ to $\pm 1.34 \mathrm{~s}$; content of muscular mass was evaluated as "above middle" or "below middle". If it was in interval from $\pm 0.67 \mathrm{~s}$ to $\pm 1.34 \mathrm{~s}$, content was characterized as "above middle" or "below middle"[7]. If the data are out of limits $\pm 1.34 \mathrm{~s}$, muscular component was evaluated as "high" or "low".

First and second year girl students attended physical culture lessons twice a week; third and forth year girl students - once a week. Every lesson lasted for 90 minutes; the training were conducted in compliance with governmental educational standards of second generation (approximate academic program for higher educational establishments in "physical culture" discipline, 2000), mainly with using of fitness-aerobics system, oriented on education of all main motion abilities.

Motion abilities were evaluated by tests, worked out in scientific-research institute of physical culture of RF. For evaluation of quickness we used 20 meters run from walking (sec); speed endurance and dexterity - shuttle run 10 times by 5 meters (sec.); strength and power endurance of upper girdle muscles - hanging (sec.); speed-power endurance of muscular, bending torso - torso raising (times); flexibility - torso bending (cm); dynamic power of lower limbs ${ }^{\text {ee }}$ muscles - long jump from the spot (cm); endurance - 5 minutes run (meters).

We calculated mean arithmetic value of indicators, $M$, mean square deviation, $s$, and standard error $m$. According to recommendations of O.Yu. Rebrova [9], we used in our work parametric methods of material's processing, considering normal Gauss distribution of the studied quantitative characteristics. Evaluation of differences ${ }^{\text {ce }}$ confidence of independent samplese mean values was fulfilled with the help of $t$-criterion of Student. Differences between indicators with level $\mathrm{P}<0.05$ was considered as statistically significant. Calculation of indicators was conducted with the help of applied programs Statistica 6.0. For optimization of primary digital material's analysis we developed authors "e program complex "Analysis of data of population's physical health" (state registration of program for computers, №2010612275, dt. 26.03.2010).

\section{Results of the research}

It was determined that muscular mass (MM) of girls from Baykal district (17-20 years old age) in average was $23.7 \pm 0.08 \mathrm{~kg}$ that was $42.4 \pm 0.1 \%$ of body mass (in the range from 25.7 to $59.4 \%$ ), and expressiveness of MM $0.49 \pm 0.002$ (in the range from 0.18 to 0.68 ). Dispersion of girls ${ }^{e e} \mathrm{MM}$ indicator was from minimal value $14.5 \mathrm{~kg}$ to maximal $-44.9 \mathrm{~kg}$.

Studying of quantitative MM content in componential composition of girls ${ }^{e e}$ bodies during four years of their study at physical culture department witnesses, that the highest content of muscular tissue was in groups of first and second year girl students, when trainings practiced twice a week. Absolute content of MM in girls ,, bodies in this period was in average $24.8 \pm 0.1 \mathrm{~kg}(44.6 \%)$. When trainings started to be practiced once a week $\left(3^{\text {rd }}-4^{\text {th }}\right.$ years $)$ there was reduction of MM content characteristics up to $23.3 \pm 0.2 \mathrm{~kg}(40.2 \%)$ and. against this background, increase of fat mass (P $<0.05)$.

It is interesting to analyze dependence of motion tests ${ }^{\text {ee }}$ results on quantitative MM content (see table). For example in speed endurance and dexterity test (shuttle run $10 \times 5$ ) the best time $20.5 \pm 0.1$ sec. was shown by girls with high level of MM content $(\mathrm{P}<0.05)$. In other levels no dependence were found. In test for quickness $(20$ meter run from walking) we registered the same dependence of indicator ${ }^{e}$ s dynamic. The best result ( $3.78 \pm 0.1 \mathrm{sec}$.) was shown by girls with high $\mathrm{MM}$ content and the lowest result $(4.03 \pm 0.1 \mathrm{sec}$.) was shown by girls with $\mathrm{MM}$ expressiveness of "below middle" (P<0.05).

Dynamic of dependence of motion tests' results on level of muscular mass's expressiveness and anthropometrical parameters of girls (17-20 years old age)

\begin{tabular}{|c|c|c|c|c|c|}
\hline \multirow{3}{*}{$\begin{array}{l}\text { Anthropometrical } \\
\text { parameters and } \\
\text { motion tests }\end{array}$} & \multicolumn{5}{|c|}{ Content of muscular mass (\% from body mass) } \\
\hline & $\begin{array}{l}\text { Low (less } \\
\text { than }-1.34 \mathrm{~s})\end{array}$ & $\begin{array}{c}\text { Below middle } \\
\text { (from }-0.67 \mathrm{~s} \text { to } \\
-1.34 \mathrm{~s} \text { ) }\end{array}$ & $\begin{array}{l}\text { Middle } \\
\mathrm{M} \pm 0,67 \mathrm{~s}\end{array}$ & $\begin{array}{l}\text { Above middle } \\
\text { (from }+0.67 \mathrm{~s} \text { to } \\
+1.34 \mathrm{~s} \text { ) }\end{array}$ & $\begin{array}{l}\text { High (more than } \\
+1.34 \mathrm{~s})\end{array}$ \\
\hline & \multicolumn{5}{|c|}{ Values of indicators and tests } \\
\hline Body length, $\mathrm{cm}$ & $165.8 \pm 0.4$ & $165.4 \pm 0.3$ & $164.9 \pm 0.1$ & $165.0 \pm 0.3$ & $166.1 \pm 0.4$ \\
\hline Body mass, kg & $56.9 \pm 0.6$ & $54.9 \pm 0.3$ & $55.8 \pm 0.1$ & $56.09 \pm 0.4$ & $56.6 \pm 0.6$ \\
\hline $\begin{array}{l}\text { Chest } \\
\text { circumference, } \mathrm{cm}\end{array}$ & $78.7 \pm 0.1$ & $82.4 \pm 0.04$ & $86.1 \pm 0.05$ & $90.7 \pm 0.05$ & $90.6 \pm 0.4$ \\
\hline $\begin{array}{l}\text { Shuttle run } 10 \times 5 \mathrm{~m} \text {, } \\
\text { sec. }\end{array}$ & $21.3 \pm 0.1$ & $21.3 \pm 0.1$ & $21.2 \pm 0.06$ & $21.1 \pm 0.1$ & $20.5 \pm 0.1$ \\
\hline $\begin{array}{l}\text { Run from walking } \\
20 \mathrm{~m} \text {, sec. }\end{array}$ & $3.97 \pm 0.04$ & $4.03 \pm 0.1$ & $3.97 \pm 0.04$ & $3.98 \pm 0.1$ & $3.78 \pm 0.1$ \\
\hline
\end{tabular}




\begin{tabular}{|c|c|c|c|c|c|}
\hline \multirow{3}{*}{$\begin{array}{c}\text { Anthropometrical } \\
\text { parameters and } \\
\text { motion tests }\end{array}$} & \multicolumn{5}{|c|}{ Content of muscular mass (\% from body mass) } \\
\hline & $\begin{array}{l}\text { Low (less } \\
\text { than }-1.34 \mathrm{~s})\end{array}$ & $\begin{array}{c}\text { Below middle } \\
\text { (from }-0.67 \mathrm{~s} \text { to } \\
-1.34 \mathrm{~s} \text { ) }\end{array}$ & $\begin{array}{c}\text { Middle } \\
\mathrm{M} \pm 0,67 \mathrm{~s}\end{array}$ & $\begin{array}{l}\text { Above middle } \\
\text { (from }+0.67 \mathrm{~s} \text { to } \\
+1.34 \mathrm{~s})\end{array}$ & $\begin{array}{l}\text { High (more than } \\
+1.34 \mathrm{~s})\end{array}$ \\
\hline & \multicolumn{5}{|c|}{ Values of indicators and tests } \\
\hline $\begin{array}{l}5 \text { minutes run, } \\
\text { meters }\end{array}$ & $837.8 \pm 20.5$ & $880.2 \pm 5.9$ & $914.2 \pm 11.9$ & $918.0 \pm 11.1$ & $918.7 \pm 14.0$ \\
\hline Hanging, sec. & $8.8 \pm 0.3$ & $9.6 \pm 0.3$ & $9.7 \pm 0.1$ & $10.3 \pm 0.3$ & $11.3 \pm 0.6$ \\
\hline $\begin{array}{l}\text { Torso raising during } \\
30 \mathrm{sec} ., \text { times }\end{array}$ & $22.7 \pm 0.5$ & $23.2 \pm 0.4$ & $23.2 \pm 0.2$ & $23.8 \pm 0.6$ & $24.7 \pm 0.2$ \\
\hline Torso bending, $\mathrm{cm}$ & $8.9 \pm 0.1$ & $15.0 \pm 0,5$ & $14.9 \pm 0.2$ & $21.3 \pm 0.1$ & $28.2 \pm 0.2$ \\
\hline $\begin{array}{l}\text { Long jump from the } \\
\text { spot, cm }\end{array}$ & $119.9 \pm 0.5$ & $133.5 \pm 0.2$ & $151.2 \pm 0.2$ & $168.9 \pm 0.2$ & $183.3 \pm 0.5$ \\
\hline
\end{tabular}

Characteristic of general endurance (test 5 minutes run) witnesses that the best result was shown by girls with high and "above high" level of muscular mass content. With it, girls with such MM content run distance by 80.9 meter longer during 5 minutes than girls with "low" level $(\mathrm{P}<0.05)$.

In power tests (hanging and torso raising) we also registered that girls with high MM expressiveness showed better results.

Similar dynamic was registered during testing of sportsmen and not sportsmen in Lithuania [5], as well as persons, who trained weight lifting as a part of physical culture program at HEE [12].

Analysis of such characteristic as flexibility witnesses that in group of girls with high MM content indicators of "torso bending" was 3.2 times higher than in groups with low muscular mass $(28.2 \pm 0.2$ and $8.9 \pm 0.1 \mathrm{~cm})$ accordingly, $\mathrm{P}$ $<0.05)$.

In test for dynamic strength of lower limbs (long jump from the spot) girls with high MM content showed result by $52.8 \%$ higher than girl students with low MM level.

\section{Conclusions}

1. Quantity of muscular mass in componential composition of girls is higher in first two years of physical culture (with lessons being conducted twice a week) $(24.8 \pm 0.1 \mathrm{~kg})$. With passing to "once a week lessons" there happens reduction of $\mathrm{MM}$ content in girls ${ }^{\mathrm{se}}$ bodies by from $4.4 \%$ to $23.3 \pm 0.2 \mathrm{~kg} \%$ and increase of fat mass against this background ( $\mathrm{P}<$ $0.05)$.

2. In group of girls with high MM content results of all motion tests were better than in groups with "low" and "below middle" MM content.

3. Deficit of girl students ${ }^{\text {se }}$ motion functioning shall be compensated with controlled independent trainings.

\section{References:}

1. Bal'sevich V.K., Lubysheva L.I. [New technologies of formation of physical culture of the schoolchild]. Problemy sovershenstvovaniia fizicheskogo vospitaniia uchashchikhsia obshcheobrazovatel'nykh shkol. Mezhdunarodnyj seminar [Problems of improving physical education pupils of comprehensive schools. International workshop]. Moscow, 1993, pp. 42-50. (in Russian)

2. Bujkova O.M., Tristan V.G. Vliianie zaniatij razlichnymi vidami aerobiki na komponentnyj sostav tela studentok [Effect of different types of aerobic training on body composition component of students]. Vestnik IuzhnoUral'skogo gosudarstvennogo universiteta. 2010, vol.19, no.195, pp. 131-134. (in Russian)

3. Dorokhov R. N., Petrukhin V. G. Mediko-pedagogicheskie aspekty podgotovki iunykh sportsmenov [Medical and pedagogical aspects of training young athletes]. Smolensk, 1989, pp. 4-14. (in Russian)

4. Zajceva V.V. Metodologiia individual'nogo podkhoda $v$ ozdorovitel'noj fizicheskoj kul'ture na osnove sovremennykh informacionnykh tekhnologij. Dokt.dis. [Methodology individual approach in improving physical training on the basis of modern information technologies. Dokt. Diss.]. Moscow, 1995, 48 p. (in Russian)

5. Zuoziene I.J., Peculiarities of physical fitness and body composition of students engaged and not engaged in sports. Physical Education of Students, 2013, no.6, pp. 15-19. doi:10.6084/m9.figshare.840494

6. Kolokol'cev M.M., Lumpova O.M. Konstitucional'naia tipologiia organizma studentov Pribajkal'ia [Constitutional typology of students"e organism of Pribaikal region]. Vestnik Irkutskogo gosudarstvennogo tekhnicheskogo universiteta. 2013, no.7, pp. 267-273. (in Russian)

7. Nikolaev V.G. Metody ocenki individual'no-tipologicheskikh osobennostej fizicheskogo razvitiia cheloveka [Methods for assessing individual typological features of physical development of a man] Krasnoyarsk, KrasGMA Publ., 2005, 111 p. (in Russian) 
8. Nikolaev V.G., Sindeeva L.V. Opyt izucheniia formirovaniia morfofunkcional'nogo statusa naseleniia Vostochnoj Sibiri [The experience of studying the formation of morphofunctional status of Eastern Siberia population]. Saratovskij nauchno-medicinskij zhurnal. 2010, vol.6, no.2, pp. 238-241. (in Russian)

9. Rebrova O.Iu. Statisticheskij analiz medicinskikh dannykh. Primenenie paketa prikladnykh programm STATISTICA [Statistical analysis of medical data. Application software package STATISTICA]. Moscow, Mediasphere, 2002, 305 p. (in Russian)

10. Khodakovski-Mal'cevich L. Zavisimost' sportivnogo rezul'tata ot razvitiia fizicheskikh kachestv $i$ morfologicheskikh pokazatelej iunoshej na etapakh predvaritel'noj podgotovki k begu. Kand. dis. [The dependence of the sports results from the development of physical qualities and morphological parameters of boys during the preliminary preparation for the run. Cand. Diss.]. 1992, 18 p. (in Russian)

11. Khristovaia T.E. Vliianie fizicheskikh nagruzok na obmen veshchestv i gormonal'nyj status liudej $\mathrm{s}$ raznym somatotipom [The influence of physical activity on the metabolism and hormonal status of people with different somatotipom]. Fizicheskoe vospitanie studentov. 2011, no.6, pp. 131-135. (in Russian)

12. Chernozub A.A. Kharakter izmenenij pokazatelej sostava tela u studentov v processe zaniatij fizicheskoj kul'turoj $\mathrm{s}$ ispol'zovaniem kompleksov atletizma [The nature of changes in body composition of students in the physical training complexes with athleticism]. Fizicheskoe vospitanie studentov. 2011, no.3, pp. 99-102. (in Russian)

13. Gautier G., Thouvarecq R., Larue J. Influence of Experience on Postural Control: Effect of Expertise in Gymnastics. Journal of Motor Behavior. 2008, vol.40, no.5, pp. 400-408.

14. Kruk J. Intensity of lifetime physical activity and breast cancer risk among Polish women. Journal of Sports Sciences. 2009, vol.27, no.5, pp. 437-445.

15. McPherson J., Anderson B., Blown E., Kirkland J., McLachlan-Smith C. Non-individual approaches to understanding human development. Early Child Development and Care. 1990, vol.55, no.1, pp. 51-57.

16. Mota J., Silva P., Santos M.P., Ribeiro J.C., Oliveira J., Duarte J.A. Physical activity and school recess time: Differences between the sexes and the relationship between children's playground physical activity and habitual physical activity. Journal of Sports Sciences. 2005, vol.23, no.3, pp. 269-275.

17. Rhodes R.E., de Bruijn G-J. Automatic and Motivational Correlates of Physical Activity: Does Intensity Moderate the Relationship? Behavioral Medicine. 2010, vol.36, no.2, pp. 44-52.

18. Scott F., Rhodes R.E., Downs D.S. Does Physical Activity Intensity Moderate Social Cognition and Behavior Relationships? Journal of American College Health. 2009, vol.58, no.3,pp. 213-222.

19. Sobko I.N., Kozina Zh.L., Iermakov S.S., Muszkieta Radosław, Prusik Krzysztof, Cieślicka Mirosława, Stankiewicz Błaźej. Comparative characteristics of the physical and technical preparedness of the women's national team of Ukraine and Lithuania basketball (hearing impaired) before and after training to Deaflympic Games. Pedagogics, psychology, medical-biological problems of physical training and sports, 2014, no.10, pp. 45-51. http://dx.doi.org/10.5281/zenodo. 10490

20. Szalma J.L., Individual differences in human-technology interaction: incorporating variation in human characteristics into human factors and ergonomics research and design. Theoretical Issues in Ergonomics Science. 2009, no.10, pp. 381-397. http://dx.doi.org/10.1080/14639220902893613 


\section{Information about the authors:}

Kolokoltsev M.M.: http://orcid.org/0000-0001-6620-6296; mihkoll@ mail.ru; National Research Irkutsk State Technical University; Lermontova str., 84, Irkutsk, 664074, Russia.

Cieslicka Miroslawa: http://orcid.org/0000-0002-0407-2592; cudaki@ op.pl; Kazimierz Wielki University in Bydgoszcz; Chodkiewicza str. 30 , 85-064 Bydgoszcz, Poland

Muszkieta Radoslaw: http://orcid.org/0000-0001-6057-1583; radek@ muszkieta.com; Kazimierz Wielki University in Bydgoszcz; Chodkiewicza str. 30, 85-064 Bydgoszcz, Poland.

Cite this article as: Kolokoltsev MM Cieslicka Miroslawa, Muszkieta Radoslaw. Optimization of physical training of students of high school with regard to quantitative features muscular components of their bodies. Physical education of students, 2015, no.1, pp. 17-21. http://dx.doi.org/10.15561/20755279.2015.0103

The electronic version of this article is the complete one and can be found online at: http://www.sportpedu.org.ua/html/arhive-e.html

This is an Open Access article distributed under the terms of the Creative Commons Attribution License, which permits unrestricted use, distribution, and reproduction in any medium, provided the original work is properly cited (http:// creativecommons.org/licenses/by/3.0/deed.en).

Received: 27.11 .2014

Accepted: 27.12.2014; Published: 30.12.2014 


\title{
CAUSES OF DECLINING INTEREST OF STUDENTS TO EMPLOYMENT PHYSICAL EDUCATION AND
} SPORTS

\author{
Kondakov V.L., Kopeikina E.N., Balysheva N.V., Usatov A.N., Skrug D.A.
} National Research University Belgorod State University, Russia

\begin{abstract}
Annotation. Purpose: analysis of the main causes of the declining interest of students to the systematic physical training and sports. Material: The study involved 448 students (150 boys, 298 girls) conducted a questionnaire survey. Level of motor activity of students was determined using pedometers. Results: It was found that the transition of students in special medical groups inevitably entail a significant reduction in motor activity (it is almost 2 times lower than that of students of the main group of health). Notes the negative trend of increasing the number of students of both sexes who consume alcoholic beverages. Marked decrease of free time students because of the need to work. Conclusions: It is suggested to use a system of specific forms of organization of work and methods of influence that meet humanistic principles "to encourage, rather than compel." The function of such methods of influence should be to achieve the restructuring of the motivational sphere of students, the adequacy of their purpose activity.
\end{abstract}

Keywords: students, physical education, physical activity, personal orientation.

\section{Introduction}

Recent time great number of specialists in field of physical education raise question about need in increase of students' interest to physical culture and sports trainings [1, 3-7, 12-21]. As on to day program in discipline "Physical culture" for HEE envisages classes for $1^{\text {st }}-3^{\text {rd }}$ year students 2 times a week ( 2 academic hours every training). These classes shall be attended by all students, who have no medical counter indications, independent on the fact if they practice any kind of sports or physical culture in free time. However, analysis of physical culture academic records showed that about one third of students systematically miss planned trainings. With it, as it was cleared up as a result of questioning, 34.7\% of respondents noted absence of interest to physical trainings as the main reason of their missing. It is undoubted that two training a week of 90 minutes duration can not replenish deficit of students' motion functioning (MF), more over actually duration of some trainings often shortens. This shortening is caused by many objective reasons (moving to places of trainings, changing of cloth, fulfillment of sanitary-hygienic requirements after trainings and so on) and by some subjective reasons (unfavorable weather conditions, students' delays caused by giving back of manuals, delays in cloak room, visiting of WC and other).

At the same time demand of young organism in motion is 14-19 thousand steps a day or 1, 3-1, 8 hours a day.

Purpose, tasks of the work, material and methods of the research

The purpose of the work is to clear up the reasons of students' interest to systematic practicing of physical culture and sports decay.

Achievement of our purpose was ensured by solution of the following tasks:

1. Theoretical analysis and generalization of problem of students' motion functioning.

2. Study specific features of students' motion functioning in condition of their studying and in everyday conditions.

3. Determine main reasons, facilitating weakening of students' interest to systematic practicing of physical culture and sports.

In order to understand the reasons, facilitating interest's weakening, in 2013-2014 teachers of physical education department of SRU "BelSU" conducted anonymous questioning of $1^{\text {st }}-3^{\text {rd }}$ year students of different specialties. In questioning 448 students participated: 150 boys and 208 girls.

Solution of tasks, determined by purpose of our research, conditioned selection of methods of the research: theoretical analysis and generalization of literature sources, questioning, talks, statistical methods.

\section{Results of the research and discussion}

Numerous researches $[1,2,3,5,11]$, conducted in recent decade, witness that about $50 \%$ of students of Russian HEEs have health abnormalities. With every coming year increment of students, who, by their health condition, are allocated in special health groups (SHG), is registered, that is proved by our research (see fig.1). Quantity of students, for whom physical trainings are prohibited at all due to their health condition, significantly increased [1, 2, 8]. Actual scope of students' MF does not ensure full fledged physical development.

\footnotetext{
(c) Kondakov V.L., Kopeikina E.N., Balysheva N.V., Usatov A.N., Skrug D.A., 2015

http://dx.doi.org/10.15561/20755279.2015.0104
} 


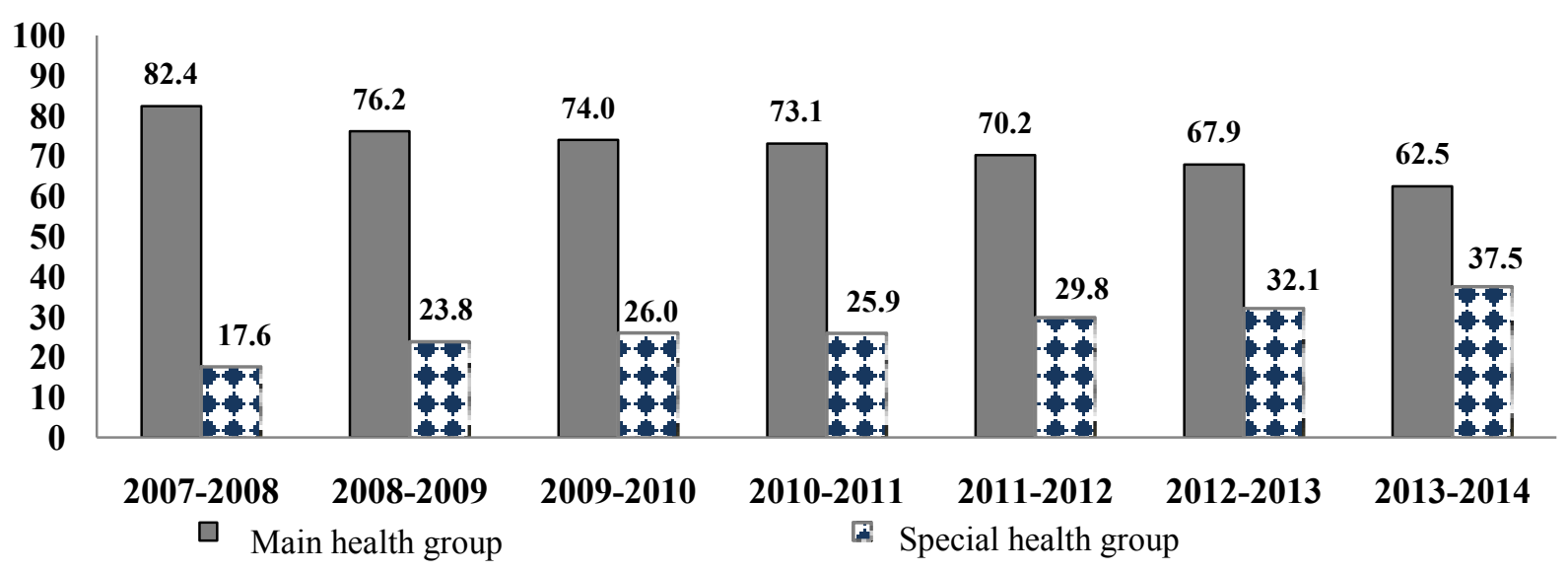

Fig.1. Correlation of students of main (MHG) special (SHG) groups in SRU “Bel SU” and

We analyzed level of students'from different health groups MF. We studied data of students' step-metering (main health group, special health group and students, released from trainings). These data are given in fig.2.

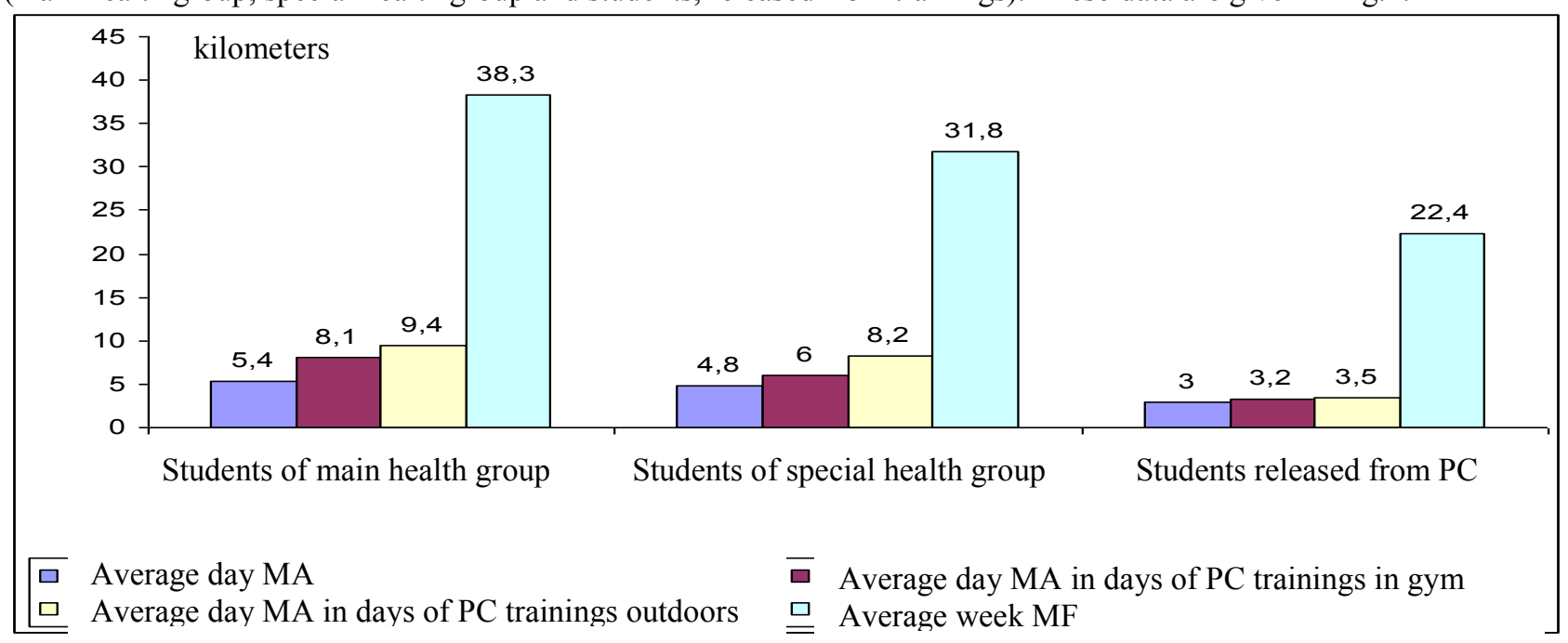

Fig.2. Motion functioning (MF) of students from different health groups (PC-physical culture)

Analysis of data witnesses that entering special health group and, more over, releasing from physical culture classes inevitably result in significant weakening of MF; with it in students, released from physical culture classes it is nearly 2 times lower than in main health group of students.

There appears certain contradiction: on the one hand MF is one of necessary components of healthy life style; it is a mean of health improvement; on the other hand young people, who have deviations in health, have indicators, reduced 2 times, while they especially need in improvement of health.

Contradiction is also in the fact that reduction of MF, being a result of health's weakening, simultaneously its reason. It is also proved by works of most of specialists [1, 10], as well as by our researches. For example quantity of students of Bielgorod HEEs, who additionally practice physical culture (in clubs or independently), reduces in proportion to increasing of students, who have health abnormalities of different heaviness (see fig.3). 


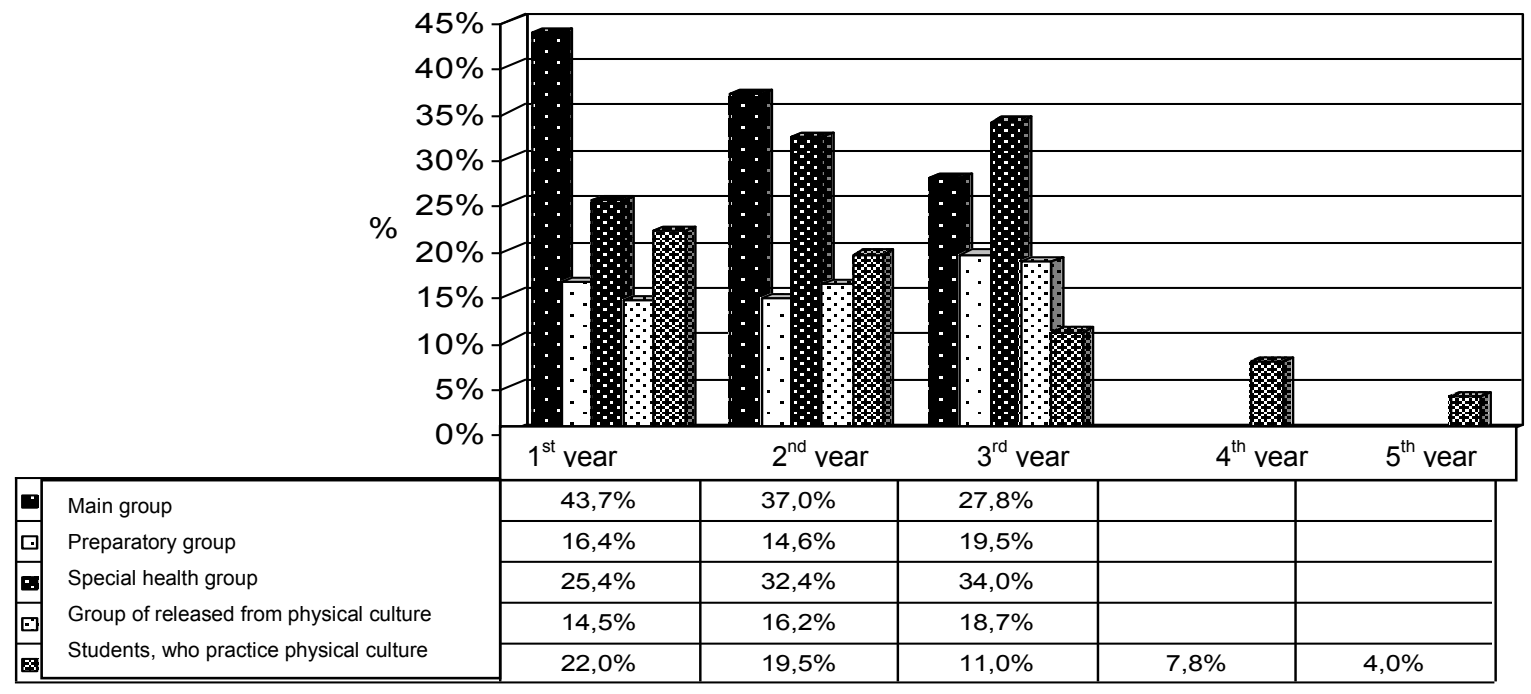

Fig.3. Dynamic of distribution of students by health groups and quantity of students, who practice physical culture additionally (PE-physical exercises, $P C$ - physical culture).

Analysis of students' answers to questions, which permit to asses their life style and determine factors, facilitating weakening of health, also cause trouble (see fig.4).

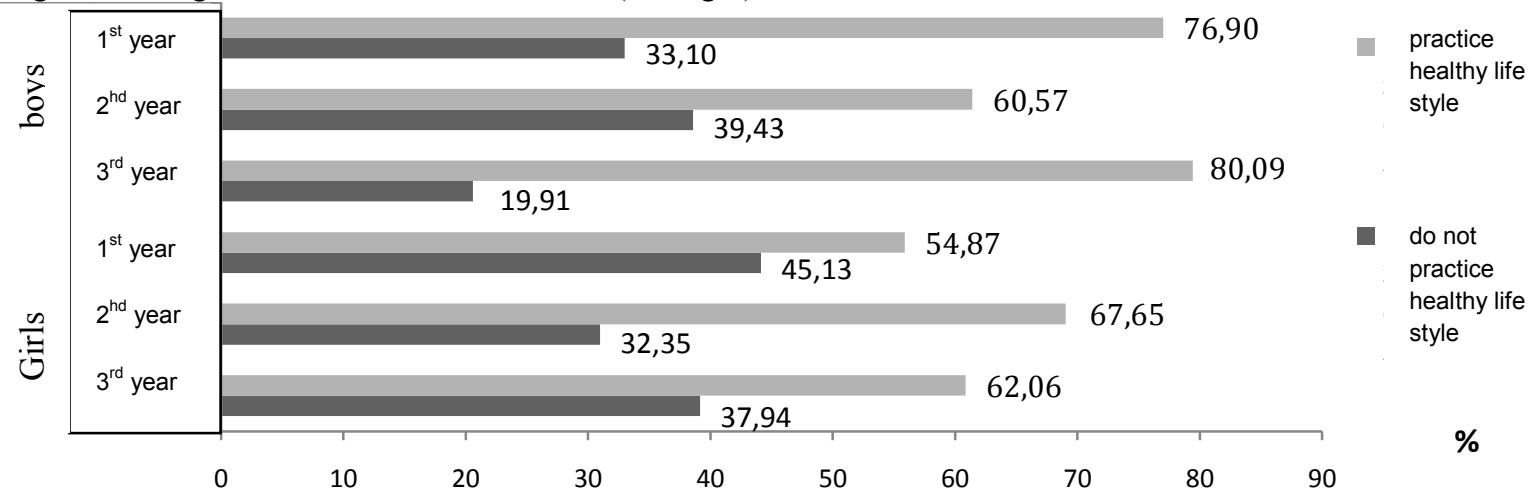

Fig.4. Self assessment of healthy life style by students of SRU "BelSU”

In spite of the fact that most of students declared their adherence to healthy life style we should note negative trend to increasing of quantity of students (boys and girls) who take alcohol (see fig.5).

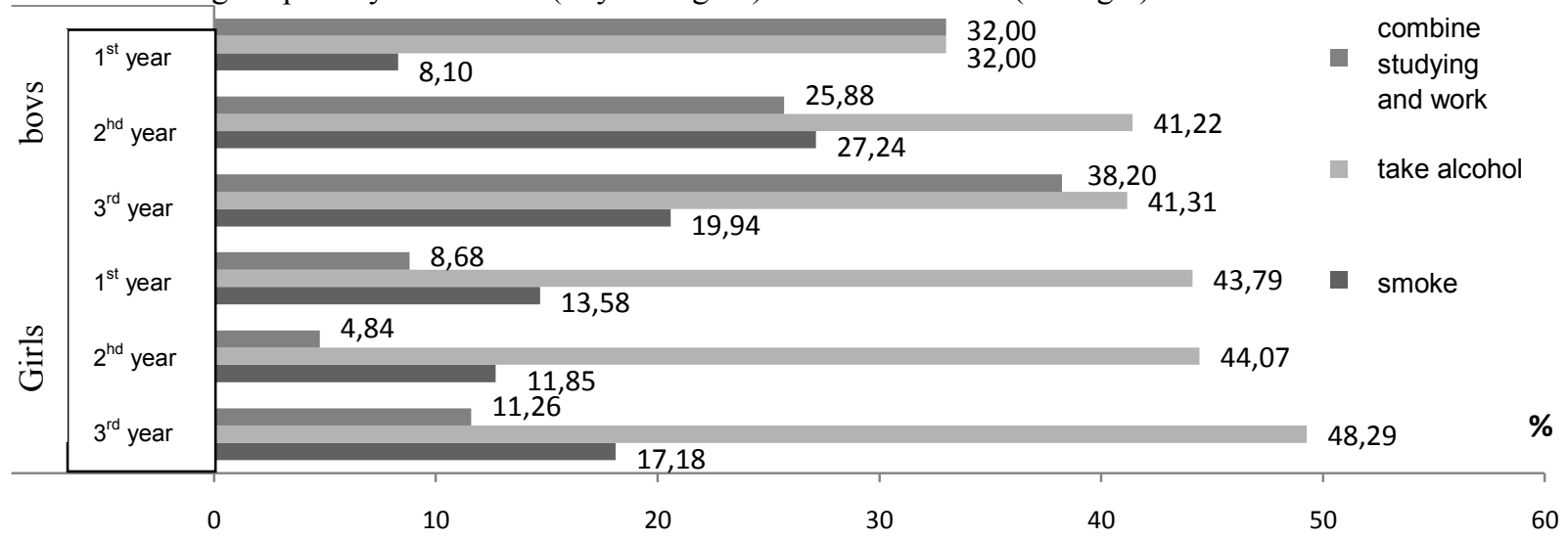

Fig.5. Negative factors in groups of SRU “BelSU” students

With it self-assessment of MF by students witnesses that their MF is not sufficient. For example most of boys characterize own MF as "above middle" and most of girls - as "middle" (see fig. 6). 
The research, conducted by us in a number of Bielgorod HEEs showed that actual students' MF is obviously lower than their self assessment. Harmful habits, reducing of MF and shortening of free time, connected with necessity to work, do not facilitate increase of interest to practicing of physical culture and sports.

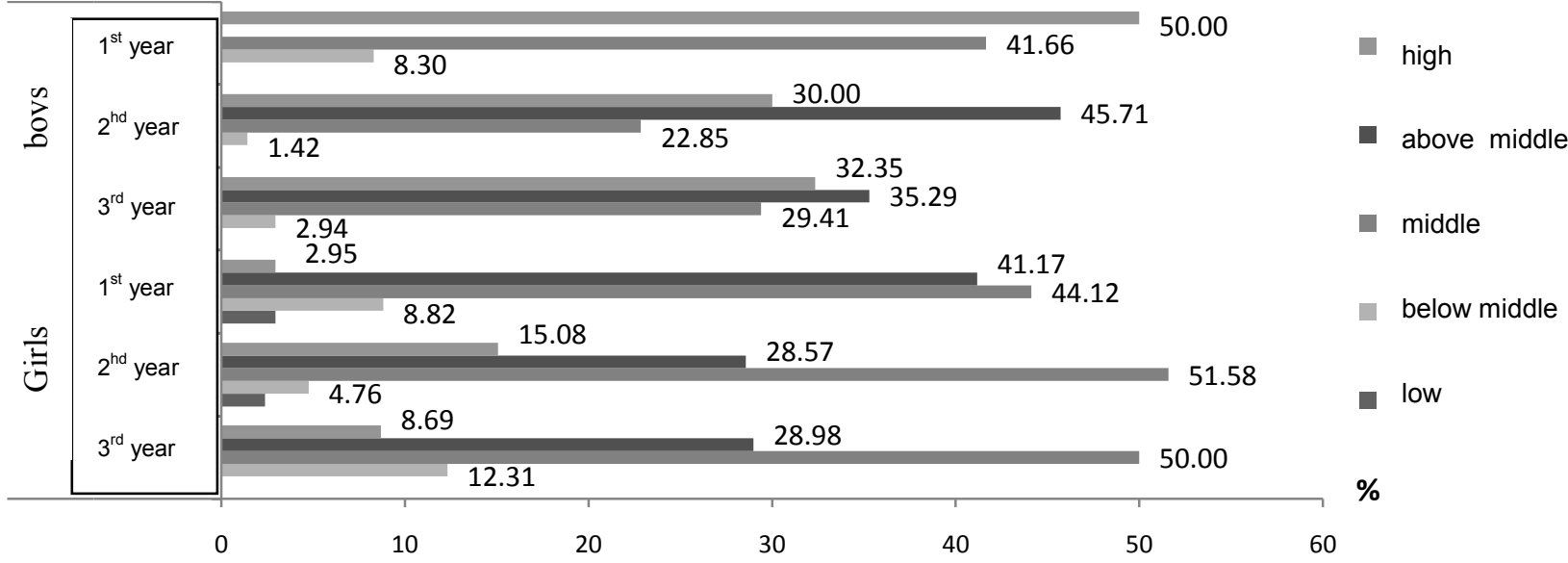

Fig.6. Self assessment of motion functioning of SRU “Bel SU” students

Analysis of formation of students' orientation on physical culture trainings permits to say that their orientation is, in the whole, poor. Among reasons of insufficient attention to own physical health, from 448 students $50 \%$ of boys and $54.5 \%$ of girls note absence of free time; indeed structure of free time to large extent influence on success of life targets', interests' and demands' formation. At present deficit of free time negatively influences on relation of youth to physical culture and sports' practicing, to taking them as desirable model of leisure.

It should be noted that $29 \%$ of girls and $4.5 \%$ of girls have practiced sports at all. Most of students do not practice physical culture besides compulsory classes, though by the data of questioning $28.5 \%$ of boys and $39 \%$ of girls point that just in their HEE there exist all conditions for physical culture and sports' practicing in convenient for them time. It was found that great majority of $1^{\text {st }}$ year students, i.e. senior pupils of yesterday $(75.8 \%)-$ attend physical culture classes because it is required by curriculum and only $9.4 \%$ attend these classes with wish.

In opinion of N.I. Ponomariov and V.M. Reisin [8] motives for physical culture practicing is the main condition of their effectiveness. Anonymous questioning of Bielgorod students showed that most of them have only one motive to receive credit, less part of students want to improve health; however, percentage of wishing to improve health is increasing with every coming year. Thus, we can conclude that first, most of students do not understand significance of physical culture for their health and future professional and life progress and second, - for most of them (students who attend trainings and who miss them) content of these classes is not interesting (see fig. 7).

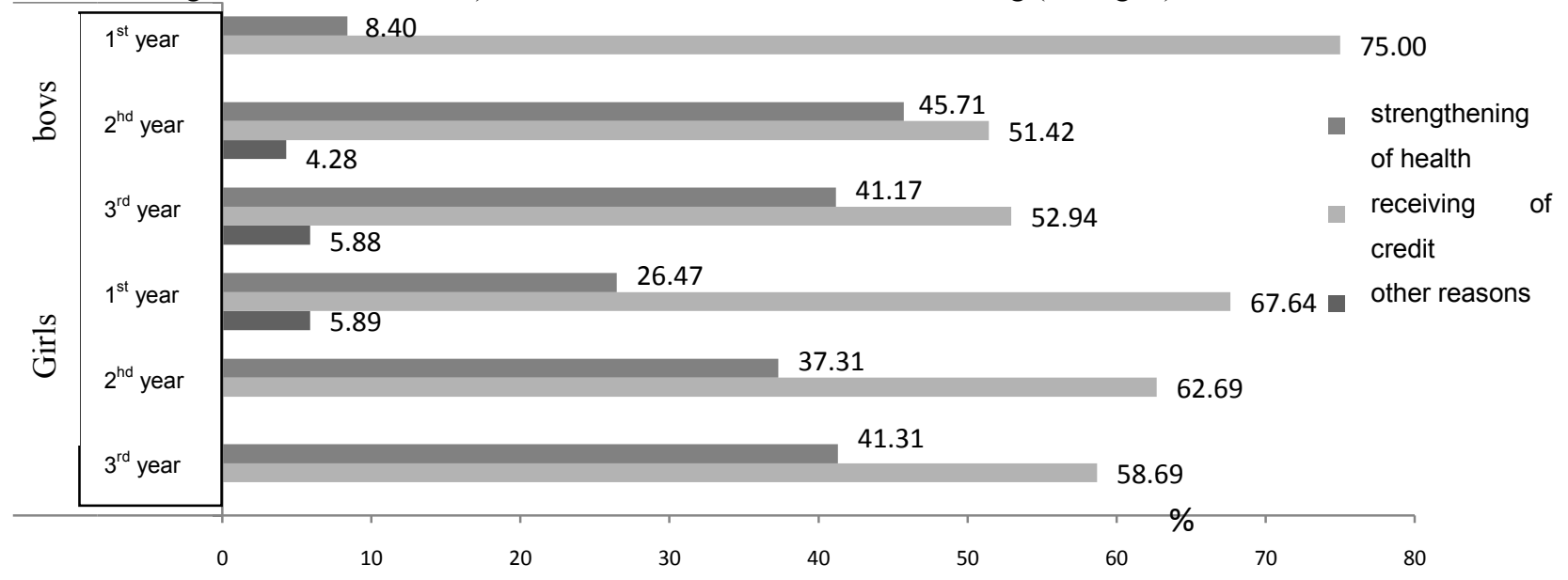

Fig. 7. Reasons of students' attendance of physical culture classes in SRW "BelSU”

The question what interest students manifested to physical culture at school, different years' students (boys and girls) was answered in somehow confusing way (see fig.8). 


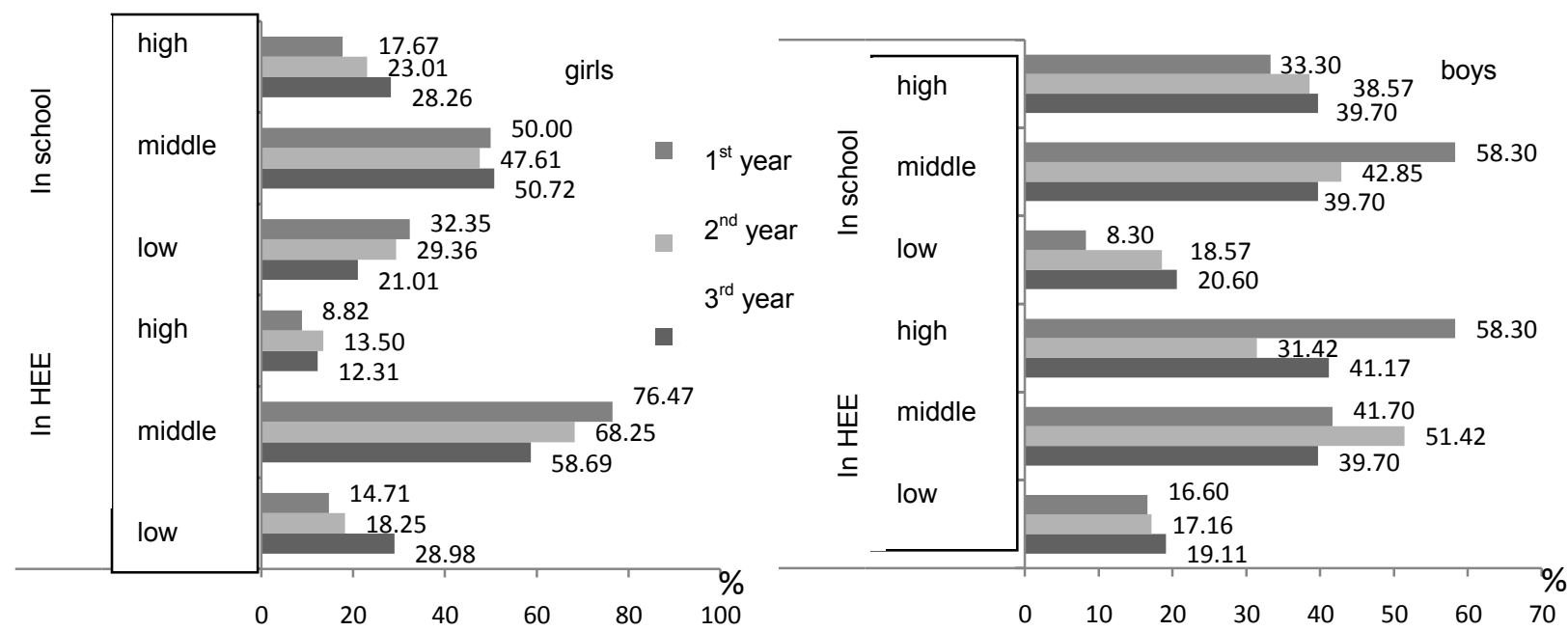

Fig.8. Interest of SRW "BelSU" students to physical culture at school and at HEE

At the first sight interest to physical culture should be equal and do not change with age. However, analysis of answers showed that with every year of studying at HEE students' interest to their physical classes at school increases. May be it is connected with some feeling of nostalgia, because it was interesting for them at school physical culture classes. Analysis of answers about interest to physical culture classes at HEE proves our assumption that with age both girls and boys loose interest to physical culture. For formation of positive emotions, increase of interest at physical culture trainings it is necessary: set clear, understood by students tasks; give, where it is necessary, scientific foundation of pedagogic and recommended methodic principles; avoid hackneyed patterns at classes, avoid monotony of used means; introduce novelty in exercises; use optimal loads and vary them; before new exercises give explanations to them; apply music (where it is possible) before exercises, in process of their fulfillment and in breaks between exercises as well as at the end of classes; consider commonality of trainees' purpose; regulate relations of trainees; form subgroups depending on their condition.

Reduction of students' MF is proved by comparison of results of answers to question about training in sport circles in school period and the, in period of study at HEE (see fig. 9). Girls stop practicing sports after school especially sharply. May be it is connected with deficit of free time, which they start to spend for preparation of home tasks, communication with new friends and so on.

Students' answers about kinds of sports, which were practiced by them in school period or are practicing at present time permitted to determine the most popular MF kinds. Most of boys marked out outdoor games. Girls also practiced often outdoor games in school period, but in student's life they start to pay attention to different aerobics.

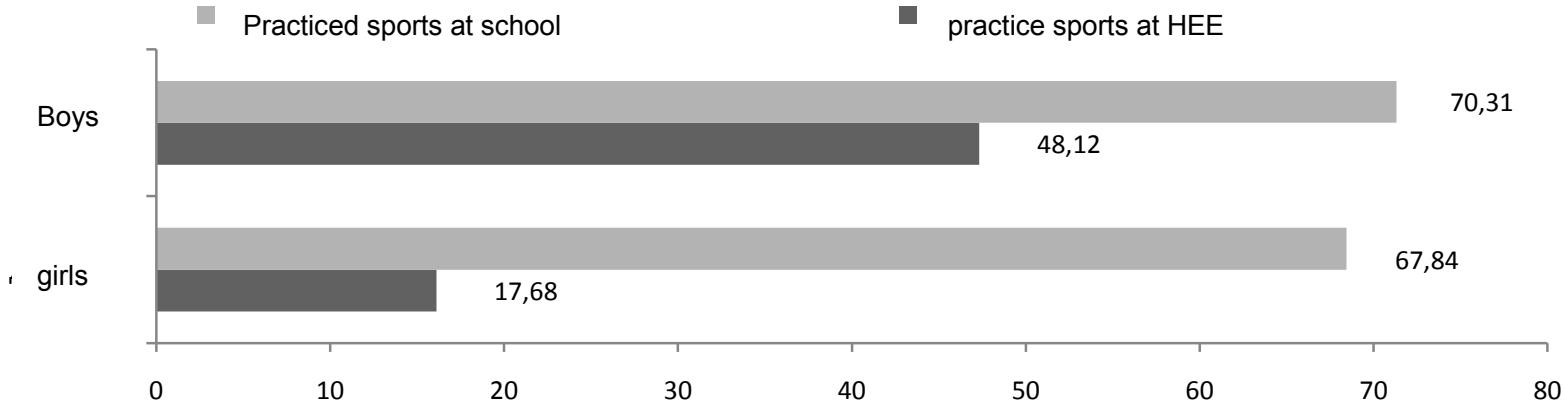

Fig.9. Attendance of sport circles by SRU "BelSU" students before entering HEE and at HEE

Students had different opinion in answers to question about changes in curriculum of "Physical culture" discipline. Most of students think it necessary to correct curriculum to some extent, the rest (minority) do not like any changes (see fig.10). In free time students can choose kinds of MF; different sport measures are organized for them at HEE sport sites. But, in spite of it, most of respondents answered that they do not participate in faculty's sport life. At senior years of studying quantity of students, participating in sport measures decreases. 


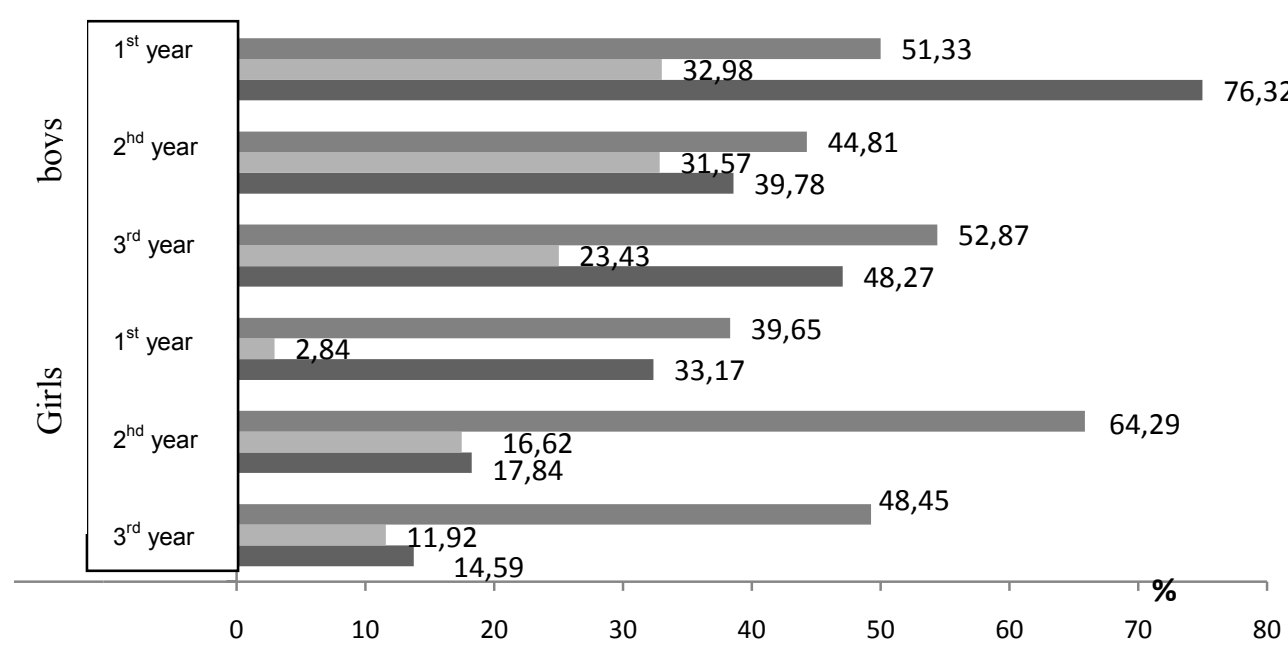

want to change content of physical culture class

participate in sport life of faculty

want to practice $\mathrm{PC}$ at $4^{\text {th }}$ and $5^{\text {th }}$ years of studying

Fig.10. Opinions about changes in physical culture and participation in faculty's sport life

There is negative trend in students' attitude possibility of physical culture classes at $4^{\text {th }}$ and $5^{\text {th }}$ years of studying. And if $1^{\text {st }}$ year students have obvious desire to continue physical culture trainings at $4^{\text {th }}$ and $5^{\text {th }}$ years, the, already $2^{\text {nd }}$ and $3^{\text {rd }}$ year students manifest weakening of such interest. Girls show even less interest to continuation of regular physical culture classes at $4^{\text {th }}$ and $5^{\text {th }}$ years of studying. Even among $1^{\text {st }}$ year girl students there is quite a few of such persons and further this quantity even became less.

It is obvious that intensification of students' MF is impossible without formation of their sincere interest to physical culture practicing and without their conscious desire to practice physical exercises additionally. Analysis of answers to question what exactly kinds of physical exercises they would like to practice is given in figure 11 .

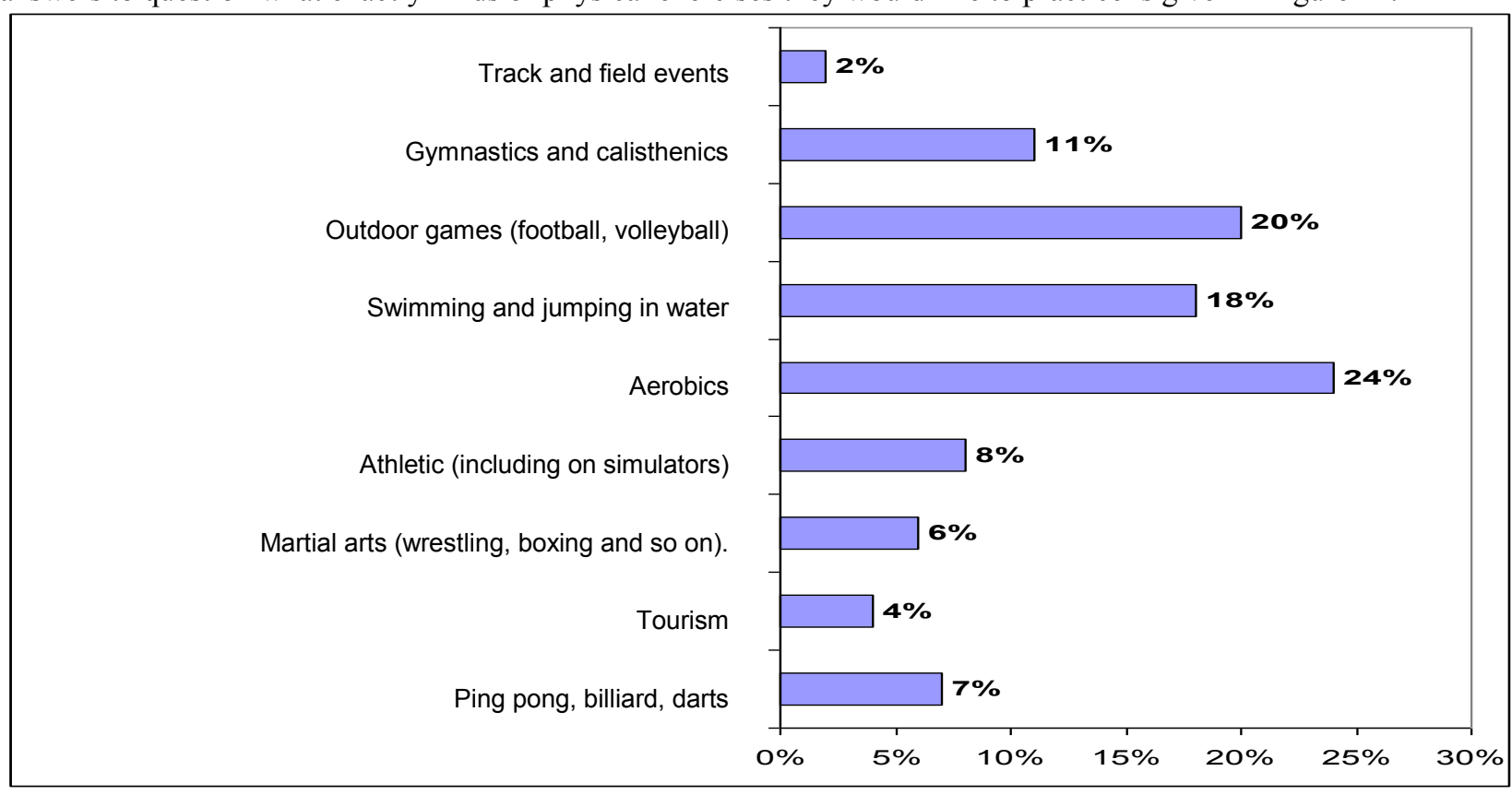

Fig.11. Kinds of physical exercises, preferred by students at physical culture classes

Significant part of the questioned (about 40\%) noted that they would like to practice interesting for them physical exercises additionally, out of academic time. Results of questioning are rather optimistic in the sense that they witness about presence of interest to MF and readiness to practice physical trainings of most of students. At the same time these results call for seeking of possibilities and ways of re-organization of physical education departments' work so that students could practice interesting for them physical exercises and for which they would be ready to find spare time.

\section{Conclusions:}

Thus, demand in increasing of students' MF is undoubted. Generalizing results of researches, conducted in Bielgorod HEEs we can conclude that MF is a necessary condition of students' health and progress. With it with years 
of studying students' MF reduces that, in its turn, results in worsening of their health and academic progress. Quantity of MF depends, first of all, on presence (or absence) of additional physical culture trainings and secondly, on group of health, in which student practice physical culture. One of reason of students' low MF is that physical culture trainings are not interesting for them and as a result about one third of students regularly miss them. Most of students do not loose interest to MF, but they would like to practice interesting for them physical exercises. The most interesting are aerobics, outdoor games, swimming. About $40 \%$ of students are ready to practice interesting for them physical exercises additionally.

Analysis of MF of SRU "BelSU" students showed that, on the one hand, it is necessary component of healthy life style, mean of health strengthening and, on the other hand, MF of young people with health abnormalities is lower nearly 2 times. This contradiction is amplified also by the fact that weakening of MF, being a result of health's worsening, is simultaneously a reason of it. This conclusion is proved by conducted by us researches, which show that main health group's students, who practice physical culture additionally, have the least percentage of morbidity. The second place is engaged by main group students, who attend only academic classes of physical culture. However, in spite of good indicators of educational functioning they have rather high percentage of catarrhal diseases. It also witnesses about prevailing significance of health in successful mastering of HEE curriculum.

All above said witnesses about demand in serious measures on cultivation of students' interest to different kinds of MF, on formation of personality's orientation on physical culture practicing and, in the whole, formation of their motivation for healthy life style.

In modern situation it is important to re understand content, methods and techniques of personality's orientation on the base of personality-active approach with pedagogic researches, analysis of subjective factors in the center. Especially troubling is absence of students' positive motivation for practicing of physical culture and sports.

It should also be noted that physical culture classes will be more effective if students realize purposes of physical culture and personal value of such trainings. That is why it is necessary to seek such methods of physical culture classes' organization, means of influence, which could more effectively ensure formation of positive personality's orientation on physical culture trainings.

In this conditions application of only traditional methods and means of influence, which often are in discordance between each other and weakly consider individual-typological features of students, are insufficiently promising. It would be more purposeful to use such holistic system of specific forms of trainings' organization and means of influence, which would meet humanistic principle "awakening instead of forcing" and, thus, increase interest of trainees to functioning, to which pedagogue orients them. Function of such means of influence shall ensure reconstruction of students' motivation sphere, adequately accepted by them purpose of functioning, resulted in positive orientation on it.

\section{References:}

1. Balysheva N.V., Bogoeva M.D., Kovaleva M.V., Kopejkina E.N., Rumba O.G. Obshchaia kharakteristika problemy deficita dvigatel'noj aktivnosti studentov s ogranichennymi vozmozhnostiami kardiorespiratornoj sistemy [General characteristics of the shortage of motor activity of students with disabilities cardiorespiratory system]. Kul'tura fizicheskaia i zdorov'e, 2013, vol.4, no.46, pp. 85-90. (in Russian)

2. Gorelov A.A., Rumba O.G., Kondakov V.L. Analiz pokazatelej zdorov'ia studentov special'noj medicinskoj gruppy [Analysis of indicators of health of students of special medical group]. Nauchnye problemy gumanitarnykh issledovanij. 2008, no.6, pp. 28-33. (in Russian)

3. Gorelov A.A., Kondakov V.L., Usatov A.N., To the question about the use of independent physical training in educational space of modern higher institute. Physical Education of Students, 2013, no.1, pp. 17-26. http://dx.doi.org/10.6084/m9.figshare.156351.

4. Gorelov A.A., Rumba O.G. , Kondakov V.L. Opyt ispol'zovaniia sredstv fizicheskoj kul'tury dlia povysheniia umstvennoj i fizicheskoj rabotosposobnosti, snizheniia nervno-emocional'nogo napriazheniia studentov $s$ narusheniiami v sostoianii zdorov'ia [Experience in the use of means of physical training to improve mental and physical performance, reduction of neuro-emotional stress of students with disabilities in the state of health]. Nauchnye vedomosti Belgorodskogo Gosudarstvennogo Universiteta, 2010, vol.6(77), no.5, pp. 185-192. (in Russian)

5. Gorelov A.A., Kondakov V.L., Rumba O.G. Fizkul'turno-ozdorovitel'nye tekhnologii kak sredstvo kinezioterapii v obrazovatel'nom prostranstve vuza [Sport and health technology as a means of physiotherapy in the educational space of the university]. Physical Education of Students, 2012, no.6, pp. $47-51$. http://dx.doi.org/10.6084/m9.figshare.96568 (in Russian)

6. Kondakov V.L., Usatov A.N, Usatov V.N., Goverdovskaia E.V. O neobkhodimosti povysheniia dvigatel'noj aktivnosti studentov vuzov [On the need to increase motor activity of university students]. Kul'tura fizicheskaia $i$ zdorov'e, 2008, vol.5, no.19, pp. 55-60. (in Russian)

7. Kondakov V.V., Kopejkina E.N., Usatov A.N., Balysheva N.V. Otnoshenie studentov k zaniatiiam fizicheskoj kul'turoj i sportom v obrazovatel'nom prostranstve sovremennogo vuza [The ratio of students to physical culture and sports in the educational space of the modern university]. Ekonomicheskie $i$ gumanitarnye issledovaniia regionov, 2014, no.3, pp. 48-52. (in Russian)

8. Kondakov V.L. Sistemnye mekhanizmy konstruirovaniia fizkul'turno-ozdorovitel'nykh tekhnologij v obrazovatel'nom prostranstve sovremennogo vuza. Dokt.diss. [System design mechanisms of health and fitness 
technology in the educational space of the modern university. Dokt. Diss.]. Sankt Petersburg,, 2013, 521 p. (in Russian)

9. Kondakov V.L. Upravlenie formirovaniem napravlennosti lichnosti shkol'nika (na materiale fizicheskoj kul'tury). Kand.diss. [Management of formation of orientation of the individual student (based on the physical culture). Kand.diss.]. Belgorod, 2000, 190 p. (in Russian)

10. Ponomarev N.I., Rejzin V.M. O formirovanii potrebnosti cheloveka $v$ fizkul'turno-sportivnoj deiatel'nosti (teoreticheskij aspekt) [On the formation of the human need for physical culture and sports activities (theoretical aspect).] Teoriia i praktika fizicheskoj kul'tury, 1988, no.10, pp. 2-4. (in Russian)

11. Alekseev N., Kutergin N., Kulinichev A., Gorbatenko A. Integrated method development of general and special students stamina involved in the fight. Physical Education of Students. 2014, no.3, pp. 3-8. http://dx.doi.org/10.6084/m9.figshare.974476.

12. Edge K., Khamsi K. International school partnerships as a vehicle for global education: student perspectives. Asia Pacific Journal of Education. 2012, vol.32, no.4, pp. 455-472. http://dx.doi.org/10.1080/02188791.2012.739964.

13. Iermakova T.S. Peculiarities of forming health culture of pupils in Poland: historical aspect. Pedagogics, psychology, medical-biological problems of physical training and sports, 2014, vol.6, pp. 16-20. http://dx.doi.org/10.6084/m9.figshare.1004090

14. Harris J. Physical education teacher education students' knowledge, perceptions and experiences of promoting healthy, active lifestyles in secondary schools. Physical Education and Sport Pedagogy. 2014, vol.19, no.5, pp. 466-480. http://dx.doi.org/10.1080/17408989.2013.769506.

15. Hemphill S.A., Plenty S.M., Herrenkohl T.I., Toumbourou J.W., Catalano R.F. Student and school factors associated with school suspension: A multilevel analysis of students in Victoria, Australia and Washington State, United States. Children and Youth Services Review. 2014, no.3, pp. 187-194. http://dx.doi.org/10.1016/j.childyouth.2013.11.022.

16. Humphrey N., Lendrum A., Barlow A., Wigelsworth M., Squires G. Achievement for All: Improving psychosocial outcomes for students with special educational needs and disabilities. Research in Developmental Disabilities. 2013, vol.34, no.4, pp. 1210-1225. http://dx.doi.org/10.1016/j.ridd.2012.12.008.

17. Macleod G., Cebula K.R. Experiences of disabled students in initial teacher education. Cambridge Journal of Education. 2009, vol.39, no.4, pp. 457-472. http://dx.doi.org/10.1080/03057640903352465.

18. Maivorsdotter N., Lundvall S. Aesthetic experience as an aspect of embodied learning: stories from physical education student teachers. Sport, Education and Society. 2009, vol.14, no.3, pp. $265-279$. http://dx.doi.org/10.1080/13573320903037622.

19. Mercier K., Doolittle S. Assessing Student Achievement in Physical Education for Teacher Evaluation. Journal of Physical Education, Recreation \& Dance. 2013, vol.84, no.3, pp. 38-42. http://dx.doi.org/10.1080/07303084.2013.767721.

20. Oh H-K., Rizzo T.L., So H., Chung D-H., Park S-J., Lei Q. Preservice physical education teachers' attributes related to teaching a student labeled ADHD. Teaching and Teacher Education. 2010, vol.26, no.4, pp. 885-890. http://dx.doi.org/10.1016/j.tate.2009.10.027.

21. Prusik Krzysztof, Prusik Katarzyna, Kozina Zh.L., Iermakov S.S. Features of physical development, physical preparedness and functional state of boys and girls - students of Polish higher educational establishments. Physical Education of Students, 2013, vol.1, pp. 54-61. http://dx.doi.org/10.6084/m9.figshare.96415 
Kondakov V.L.: http://orcid.org/0000-0002-8094-0144; kondakov@bsu. edu.ru; National Research University Belgorod State University; Pobeda 85, Belgorod, 308015, Russia.

Kopeikina E.N.: http://orcid.org/0000-0002-6027-3495; kopeikina@ bsu.edu.ru; National Research University Belgorod State University; Pobeda 85, Belgorod, 308015, Russia.

Balysheva N.V.: http://orcid.org/0000-0003-3657-8448; balysheva@ bsu.edu.ru; National Research University Belgorod State University; Pobeda 85, Belgorod, 308015, Russia.

Usatov A.N.: http://orcid.org/0000-0002-9148-5060; usatov@bsu.edu. ru; National Research University Belgorod State University; Pobeda 85, Belgorod, 308015, Russia.

Skrug D.A.: http://orcid.org/0000-0002-9570-4961; skrug@bsu.edu. ru; National Research University Belgorod State University; Pobeda 85, Belgorod, 308015, Russia.

Cite this article as: Kondakov V.L., Kopeikina E.N., Balysheva N.V., Usatov A.N., Skrug D.A. Causes of declining interest of students to employment physical education and sports. Physical education of students, 2015, no.1, pp. 22-30. http://dx.doi. org/10.15561/20755279.2015.0104

The electronic version of this article is the complete one and can be found online at: http://www.sportpedu.org.ua/html/arhive-e.html

This is an Open Access article distributed under the terms of the Creative Commons Attribution License, which permits unrestricted use, distribution, and reproduction in any medium, provided the original work is properly cited (http:// creativecommons.org/licenses/by/3.0/deed.en)

Received: 27.11.2014

Accepted: 06.12.2014; Published: 30.12.2014 


\title{
RATIONALE SET OF INDICATORS AND PRIORITIZE RELEVANT TO ASSESS COMPETITIVE ACTIVITY OF HOCKEY PLAYERS OF HIGH QUALIFICATION OF DIFFERENT ROLES
}

\author{
Mikhnov A.P.
}

National University of Physical Education and Sport of Ukraine

\begin{abstract}
Annotation. Purpose: organize technical and tactical actions and determine their priority importance for high-end players of different roles. Establish their priority importance for the success of competitive activity hockey with the game roles. Material: the study involved 54 experts on hockey coaches and players of high class. The significance of technical and tactical actions evaluated for players of different roles. Results: systematic account of technical and tactical actions of athletes and prioritize them to assess the significance of competitive activity. Three groups of technical and tactical actions: 1) active attacks; 2) - active safety; 3 ) - organizational and maneuvering. Set priorities for technical and tactical actions for players of different roles. Conclusions: the proposed technical and tactical actions can be recommended for the evaluation of the effectiveness of competitive activity players. In the process of estimating the action game players need to consider their role playing. Identification of priority in the implementation of technical and tactical actions in the game can be used in integrated assessment of actions players different roles.
\end{abstract}

Keywords: competitive, activities, technique, tactics, reliability index, indicator of success.

\section{Introduction}

Perfection of management of competition functioning on the base of objectification of knowledge about its structure and provisioning components is one of the most important tasks of sportsmen training system's formation in game kinds of sports $[5,6,7,11,17,20]$.

Prestige character and popularity of sport games, their high level of competitiveness at international sport arena and importance of sport result are so evident that urgency of questions, connected with increasing of competition functioning's effectiveness is out of the question [1-3,12-15,19].

One of the most important problems in sport games in general and in hockey in particular is evaluation of competition functioning. Total sport result of a collective does not always permits to reflect competition functioning of separate players $[4,8,9,18]$.

Active counter action of adversary requires instant change of previously worked out plan of individual hockey player's and team's actions. Sportsmen have to act in conditions of expressed deficit of time with changes of game situation and demand in adequate response [10].

For evaluation of actions in match specialists consider qualitative and quantitative characteristics of technical tactic actions. Such actions are means of realization of sport duel's tasks and they also serve as the most informative criteria, permitting to reflect sportsman's behavior in match and effectiveness of his actions [8,16]. However, with it, it is necessary to consider the fact that hockey players of different roles have different priorities in realization of different tasks in match.

Thus, in present research we have tried to systemize technical tactic actions, fulfilled by hockey players in competition functioning and to determine their priority importance for hockey players of different roles. The work has been fulfilled in the frames of scientific research topic 2.4. "Theoretical methodic principles and individualization of training process in game kinds of sports" in compliance with combined plan of SRW in sphere of physical culture and sports for 2011-2015.

Purpose, tasks of the work, material and methods

The purpose of the work is to systemize technical tactic actions and determine of their priority significance for highly qualified hockey players of different roles.

The tasks of the research were to determine and systemize technical tactic actions, offered by specialists for evaluation of competition functioning, determination of their priority significance for successful competition functioning of highly qualified hockey players, considering their roles in match.

The methods of the research: pedagogic observation and generalization of special scientific-methodic literature data, expert questioning, analysis of Internet data. In researches 54 experts participated, who, in order of priority, determined significance of technical tactic actions for hockey players of different roles.

Results of the research

Analysis of special scientific-methodic literature and questioning of hockey experts showed that in competition functioning hockey players fulfill great number of different technical-tactic actions and every of them influence on sport duel's process and can, to some or other extent, influence on its result.

In total more than thirty separate match actions were marked out, which can be conventionally divided (for systemizing) into three main groups (see fig.1) Detail grouping and differentiation were determined by sense similarity of actions and their relation to different phases of match.

So, in separate group we can mark out those technical-tactic actions, which are oriented on active attack of adversary's net and sharpening of attacking phase - group of active attacking actions.

\footnotetext{
(C) Mikhnov A.P., 2015

http://dx.doi.org/10.15561/20755279.2015.0105
} 


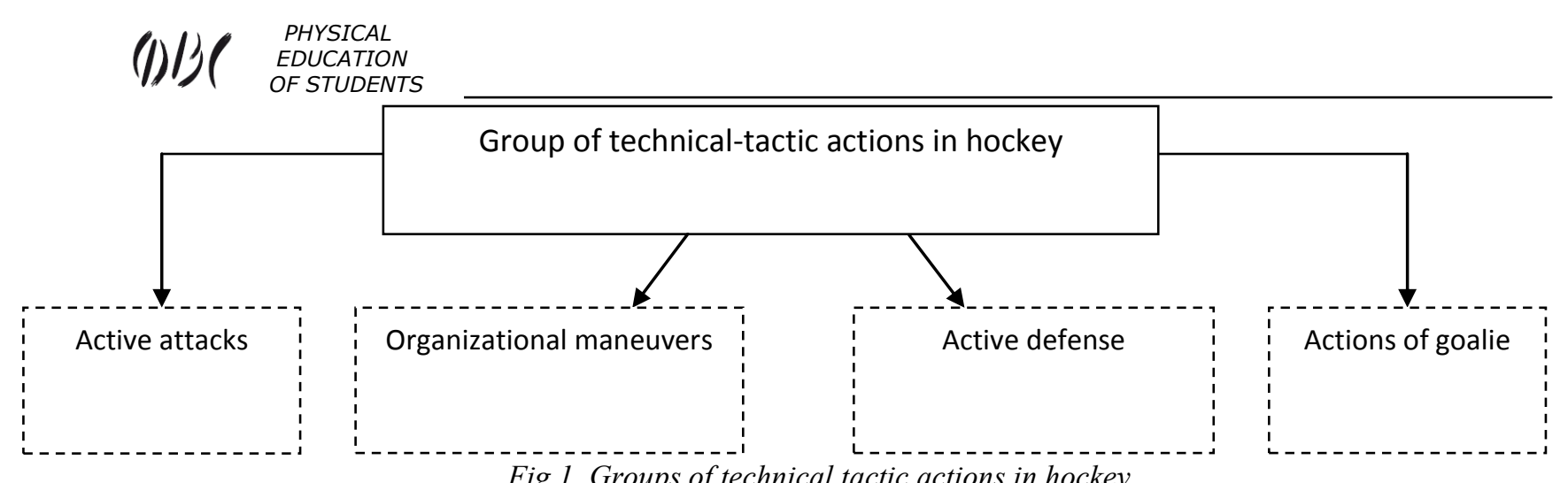

Fig. 1. Groups of technical tactic actions in hockey

The second group contains technical-tactic actions, oriented on organization of hockey players' actions and their skating on field, maneuvering and current interaction, i.e. organizational-maneuvering actions.

The third group (active defensive actions) consists of hockey players' actions, oriented on defense of net and active picking up of puck.

Technical-tactic actions, fulfilled by goalie can be marked out in separate group - game of hockey goalie.

So, among active attacking actions experts offer to mark out throws in hockey net, thrown in pucks, efficient passes, duels with adversary's goalie. Besides, to day indicator of gained scores (sum of thrown in pucks) is used as important indicator for highly qualified hockey players.

Group of organizational-maneuvering actions contains the most of actions, which can be fulfilled both in phase of defense and in phase of attack.

In this group, among main technical-tactic actions the following can be marked out: dribbling of puck, maneuvering on skates, cheating of adversary (by long trajectory, short, with strength), passes of puck (excluding efficient), catching of puck by body, coming out of adversary's guiding, choosing of position and etc.

This group can also include fight of hockey players at throw of puck on field because successful or unsuccessful start can influence on further organizational actions of team.

The third group - active defensive actions - includes the following: picking up of puck, power fight, repelling of puck and etc.

Besides, specialists offer to mark out a number of indicators, which characterize effectiveness of competition functioning of goalie. These indicators in general characterize successfulness of repelling of pucks from net. As informative indicators they mark out the following: quantity of throws in net, quantity of missed pucks, percentage of missed pucks, index of reliability (integral index of match's effectiveness).

As a result of questioning experts marked out and offered to use in our further researches the following informative technical-tactic actions and indicators of hockey players: fulfilled throws in net; thrown in pucks; percentage of throws' realization; quantity of power techniques; penalty minutes for violation of rules; efficient passes, successful throws of puck on field; pucks, repelled from net; picking ups of pucks; realized obstacles for goalkeeper; support of partner; loss of puck; gained scores; indicator of successfulness $+/$.

Separately for evaluation of competition functioning of goalie experts marked out the following technicaltactic actions and indicators: missed pucks; repelled pucks; percentage of repelled pucks; index of reliability (integral indicator, conv. un.).

In order to determine the most significant technical-tactic actions for highly qualified hockey players of different roles we conducted questioning of experts, hockey specialists (see fig.2). Concordance coefficient was $\mathrm{W}=0.76$, that witnesses about high concordance of experts, hockey specialists.

For example for winger experts related to the most significant technical tactic actions the following: thrown in pucks- $15 \%$, gained scores in match- $15 \%$, percentage of throws' realization- $14 \%$ total quantity of throws in net- 10 $\%$. For center forward, in opinion of experts, technical-tactic actions of priority are: thrown in pucks $-16 \%$, gained scores $-14 \%$, percentage of throws' realization $-13 \%$. 


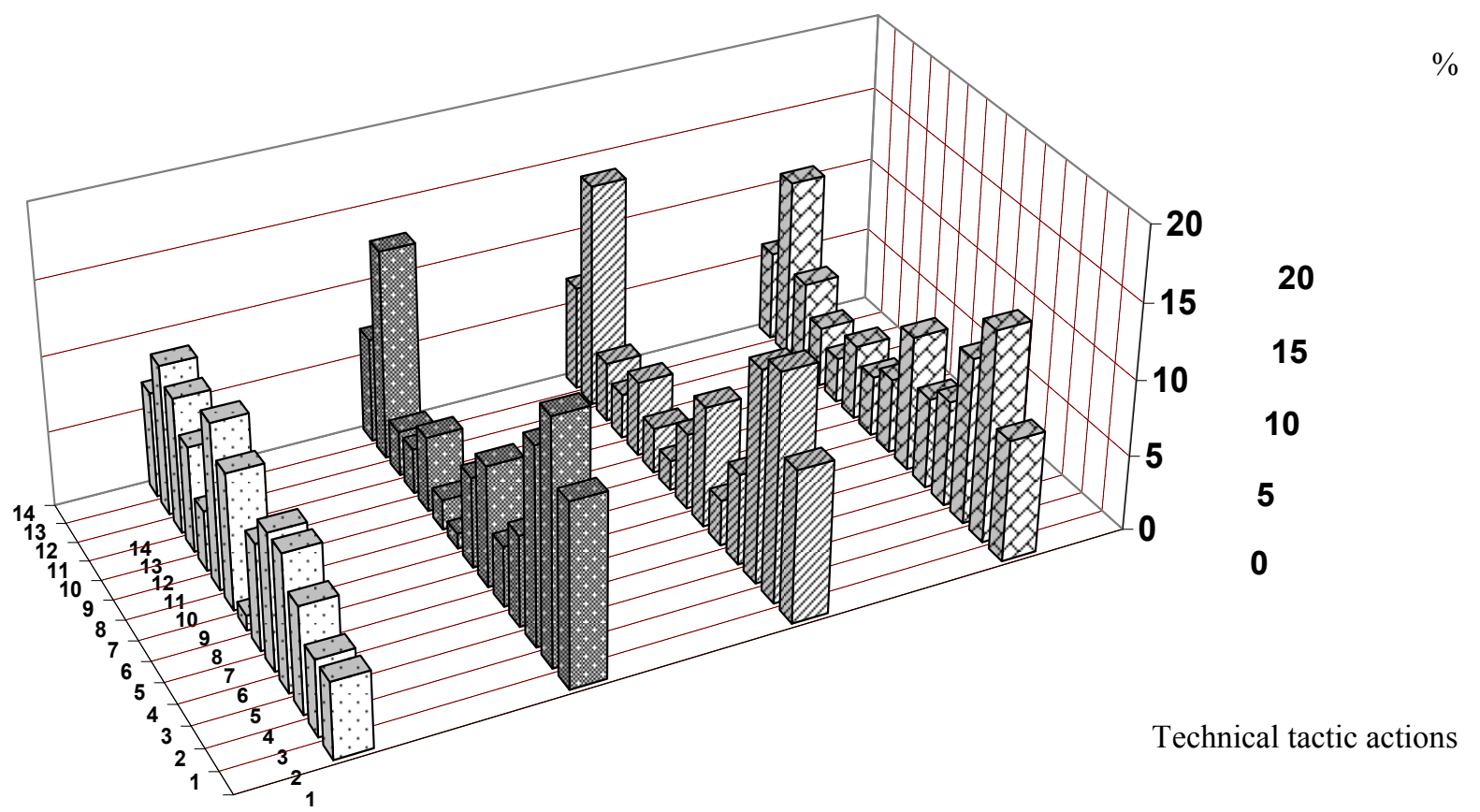

Fig.2. Significance of technical-tactic actions for highly qualified hockey players of different roles (in experts' opinion, $n=54)$ :
Без у방
ר进 winger;
center forward;
UTil back

1 - Throws in netl; 2 -thrown in pucks; 3 - percentage of throws' realization; 4 - power techniques; 5 penalty minutes; 6 -efficient passes; 7 -successful throws on field; 8 -repelled pucks; 9 -picking ups of puck; 10 obstacle to goalkeeper; 11 - support of partner; 12 -loss of puck; 13 - the gained scores; 14 - indicator of successfulness +/.

Among the most significant technical-tactic actions of a back, experts marked out the following: picking up of puck - $10 \%$, gained scores- $10 \%$, power techniques- $9 \%$, losses of puck repelled from net pucks $-9 \%$, indicator of successfulness (+/-) - $7 \%$. One of main tasks of backs is defense of own net, repelling of adversary's pucks, directed to net. During match backs shall conduct personal duels, use power techniques.

Also we separately conducted expert questioning about significance of actions in match for goalie. This way or another all technical-tactic actions and match indicators, which are used at present for evaluation of hockey goalie competition functioning, are connected with his skills in repelling throws to goal. From the offered by experts indicators the most significant are: missed pucks $-32 \%$, index of reliability -25 points, percentage of repelled pucks $-22 \%$, repelled throws in net- $21 \%$ (see fig. 3 ).

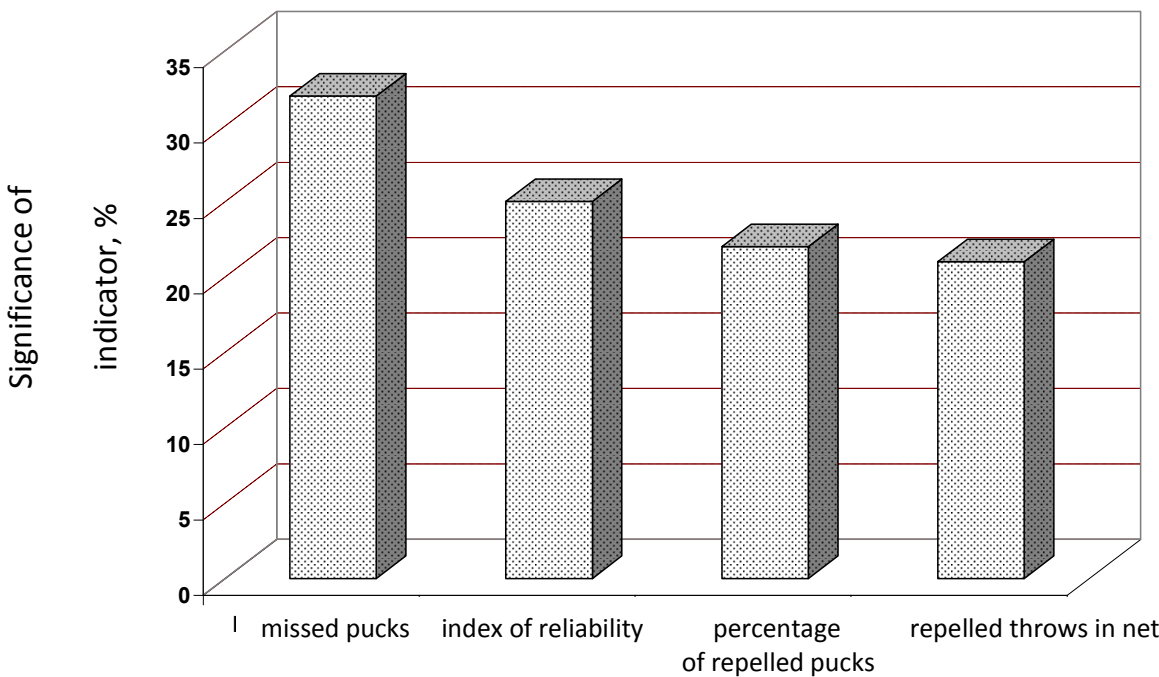

Fig.3. Significance of match indicators for highly qualified hockey goalkeeper (in experts' opinion, $n=54$ ): 
In specialists' opinion, good goalie shall have perfect reaction, ability to take correct position in front of hockey net and organize coordinated actions of partners in defense. Important qualities in hockey goalkeeper's actions are abilities for instant responding and anticipation.

\section{Conclusions:}

1. The conducted analysis of literature sources, pedagogic observations and questioning of experts permitted to systemize technical tactic actions, fulfilled by highly qualified hockey players in match and conventionally divide them into three relatively independent groups: 1) active attacking actions; 2) organizational-maneuvering actions; 3) active defensive actions; 4) actions of hockey goalie.

2. As a result of conducted exerts' questioning we determined the most informative indicators, which are recommended to be used for control and evaluation of hockey players' competition functioning: fulfilled throws in hockey net; thrown in pucks; percentage of realization of throws in net; fulfilled power techniques; penalty minutes for violation of rules; efficient passes of puck; successful throws on field; repelled from hockey net pucks; picked up pucks; obstacles for hockey goalie; support of partner; loss of puck; gained scores; indicator of successfulness (+/-). For hockey players of different roles expert marked out as technical tactic actions of first priority the following: for winger they are thrown in net pucks $-15 \%$, gained in match scores- $15 \%$, percentage of throws' realization- $14 \%$. For center forward: thrown in net pucks - Для 16\%, gained scores- $14 \%$, percentage of realization of throws in hockey net- $13 \%$. For backs: picking up of pucks- $10 \%$, gained scores- $10 \%$, power techniques- $9 \%$, потери шайбы - $9 \%$, repelled from net pucks- $9 \%$

The prospects of further researches imply working out of model characteristics of technical tactic actions of different roles' highly qualified hockey players as well as analysis of influence of personality's psychological features on hockey players' competition functioning.

\section{References:}

1. Ajrapet'ianc L.G. Pedagogicheskie osnovy planirovaniia i kontrolia uchebno-trenirovochnoj $i$ sorevnovatel'noj deiatel'nosti $v$ sportivnykh igrakh. Dokt.diss. [Pedagogical bases of planning and control for training and competitive activity in sports. Dokt. Diss.]. Moscow, 1992, 41 p. (in Russian)

2. Babushkin V.Z. Specializaciia v sportivnykh igrakh [Specialization in sports games]. Kiev, 1991,161 p. (in Russian)

3. Bezmylov N.N. Obosnovanie kompleksa informativnykh pokazatelej i opredelenie ikh prioritetnoj znachimosti dlia otbora kvalificirovannykh basketbolistov $\mathrm{v}$ komandu [Justification complex informative indicators and determining their priority importance to the selection of qualified basketball team]. Fizicheskoe vospitanie studentov, 2010, no.2, pp. 18-23. (in Russian)

4. Godik M.A., Skorodumova A.P. Kompleksnyj kontrol' v sportivnykh igrakh [Complex control in sports games]. Moscow, 2010, 336 p. (in Russian)

5. Keller V.S. Sorevnovatel'naia deiatel'nost'v sisteme sportivnoj podgotovki. Sovremennaia sistema sportivnoj podgotovki [Competitive activity in the athletic training]. Moscow, 1995, pp. 41-50. (in Russian)

6. Kozina Zh.L. Individualizaciia podgotovki sportsmenov v igrovykh vidakh sporta [Individualization of training of athletes in team sports]. Kharkov, 2009, 396 p. (in Russian)

7. Kostiukevich V. Integral'naia ocenka tekhniko-takticheskoj deiatel'nosti vysokokvalificirovannykh igrokov $\mathrm{v}$ khokkee na trave [Integral assessment of technical and tactical activity of highly skilled players in field of hockey]. Nauka v olimpijskom sporte, 2008, no.1, pp. 32-40. (in Russian)

8. Krasnikov A.A. Osnovy teorii sportivnykh sorevnovanij [Fundamentals of the theory of sports competitions]. Moscow, 2005, 160 p. (in Russian)

9. Latyshkevich L.A., Vorob'ev M.I., Bukhtij L.G. Problema povysheniia effektivnosti sorevnovatel'noj deiatel'nosti $\mathrm{v}$ sportivnykh igrakh [The problem of increasing the efficiency of competitive activity in sports games], Nauka $v$ olimpijskom sporte, 1997, no.2, pp. 13-16. (in Russian)

10. Platonov V.N. Sistema podgotovki sportsmenov v olimpijskom sporte [The system of preparation of sportsmen in Olympic sport], Kiev, Olympic Literature, 2004, 808 p. (in Russian)

11. Portnov Iu.M. Teoreticheskie $i$ nauchno-metodicheskie osnovy podgotovki kvalificirovannykh sportsmenov $v$ igrovykh vidakh sporta. Dokt.diss. [Theoretical and methodological bases of preparation of qualified athletes in team sports. Dokt. Diss.]. Moscow, 1989, 51 p. (in Russian)

12. Savenkov G.I. Psikhologicheskaia podgotovka sportsmena $v$ sovremennoj sisteme sportivnoj trenirovki [Psychological training of athlete in the modern system of sports training]. Moscow, Physical Culture and Sport, 2006, 96 p. (in Russian)

13. Temchenko V.A. Registraciia, obrabotka i analiz pokazatelej sorevnovatel'noj deiatel'nosti $\mathrm{v}$ sportivnykh igrakh [Registration, processing and analysis of competitive activity in sports games]. Fizicheskoe vospitanie studentov tvorcheskikh special'nostej, 2006, no.2, pp. 37-48. (in Russian)

14. Shinkaruk O.A., Bezmilov M.M. Teoretiko-metodichni zasadi rozrobki ta vikoristannia model'nikh kharakteristik tekhniko-taktichnikh dij basketbolistiv visokoi kvalifikacii [Theoretical and methodological basis for the development and use of model performance technical and tactical basketball skill]. Teoriia $i$ metodika fizichnogo vikhovannia i sportu, 2013, no.2, pp. 35-44. (in Ukrainian)

15. Shustin B.N. Model'nye kharakteristiki sorevnovatel'noj deiatel'nosti. Sovremennaia sistema sportivnoj podgotovki [Model characteristics of competitive activity]. Moscow, 1995, pp. 226 - 237. 
16. Bompa T.O., Carrera M. Periodization training for sports. Chapmaign, Human Kinetics, 2005, 259 p.

17. Enciu S.L. Hockey. For children and juniors. Quidde book for young coaches. Romanicu Field Hockey Federation. 2001, 272 p.

18. Trninić S., Dizdar D. Performance Evaluation Criteria. Coll. Antropol. 2000, vol.24, no.1, pp. $217-234$.

19. Platonov V.N. Qualified Sportsmen Training. Moscow, Physical Culture and Sports, 1986, 255 p.

Information about the author:

Mikhnov A.P.: http://orcid.org/0000-0002-7179-1554;

kaupervud2022@mail.ru; National University of Physical

Education and Sport of Ukraine; Fizkultury str. 1, Kiev, 03680 , Ukraine.

Cite this article as: Mikhnov A.P. Rationale set of indicators and prioritize relevant to assess competitive activity of hockey players of high qualification of different roles. Physical education of students, 2015, no.1,pp. 31-35.http://dx.doi.org/10.15561/20755279.2015.0105

The electronic version of this article is the complete one and can be found online at: http://www.sportpedu.org.ua/html/arhive-e.html

This is an Open Access article distributed under the terms of the Creative Commons Attribution License, which permits unrestricted use, distribution, and reproduction in any medium, provided the original work is properly cited (http:/ creativecommons.org/licenses/by/3.0/deed.en).

Received: 12.11 .2014

Accepted: 12.12.2014; Published: 30.12 .2014 


\title{
STABILITY OF EQUILIBRIUM IN UPRIGHT STANCE AND VOLUNTARY MOTION CONTROL IN ATHLETES-SHOOTERS IN THE PROCESS OF READY POSITION AND TARGET SHOOTING Pryimakov A.A. ${ }^{1}$, Eider E. ${ }^{1}$, Omelchuk E.V. ${ }^{2}$ \\ Szczecin University, Poland ${ }^{1}$ \\ M.P. Dragomanov National Pedagogical University ${ }^{2}$
}

\begin{abstract}
Annotation. Purpose: consists in studying the relationships between the system of equilibrium regulation in upright stance and voluntary motion control in athletes-shooters during ready position and target shooting. Material: 19 highly skilled athletes specialized in pistol shooting were studied. Physiological and biomechanical characteristics of posture and voluntary motions were assessed by methods of stabilography, electromyography and tremorometry; besides, accuracy of target shooting was registered. Results: high degree of shooting accuracy dependence on posture somatic parameters has been revealed, of which the greatest impact upon the result is exerted by low-frequency vibrations of the body general centre of mass, subjected to voluntary control. Prognostic models of shooting accuracy dependence upon the character of posture regulation during ready position and the shot have been developed. Conclusions: obtained results reveal the mechanisms of functioning and interacting of two systems of management - posture and voluntary motion. Elaborated regression models permit to model and predict posture stability and shooting accuracy during ready position and the shot.
\end{abstract}

Key words: orthograde posture, equilibrium, accuracy, relationships, athletes-shooters.

\section{Introduction}

It is known that in the process of long-term adaptation to physical loads (PL) mechanisms of upright posture regulation are improved in athletes, and provide not only the high quality and reliability of equilibrium maintenance under extreme conditions of athletic activity but determine the quality and reliability of voluntary motion control to a great extent as well $[8,14,16,19,20]$.

System approach in biological studies has demonstrated that both posture regulation and voluntary motion control are realized by hierarchically organized functional systems (FS) with clearly defined final adaptive outcome of the activity of each system [1, 2, 8, 10]. Interaction of FS may be realized at different levels of each system [8]. It depends on the structural and functional organization of both the voluntary motion and assumed posture, which preceds it and interacts with it both at the stage of "afferent synthesis" and "decision making" [1,9] and in the process of formation and realization of voluntary motion program [2, 3, 18]. However, interaction mechanisms of functional systems of upright posture regulation and voluntary motion control are rather insufficiently highlighted in the literature from system positions: that is, from position of their hierarchically organized component interactions and final adaptive results of each system [5, 10, 11]. Peculiarities of improvement of these interactions in the process of long-term adaptation to physical loads are insufficiently covered in the literature as well.

The objective of this work consists in studying the relationships between the system of equilibrium regulation in upright stance and that of voluntary motion control in athletes-shooters during ready position and target shooting.

Purpose, tasks of the work, material and methods

Methods of combined multiparameter registration of physiological and biomechanical characteristics of posture and voluntary motions including stabilography, electromyography, tremorometry, pulsometry, target shooting accuracy were used $[8,9,12]$.

Eighting highly skilled pistol shooterts participated in studies.

Mechanisms of posture regulation were studied during equilibrium maintenance in three upright stances: the Romberg stance (posture 1), the common stance (posture 2) and complicated upright stances (postures 3-4) during ready position, just before and during target shooting.

In one case the posture was complicated by four-time pistol lifting and holding in outstretched arm until fatigue (posture 3), whereas in the other - by upright stance maintenance with knee joint angle equal to $110^{\circ}$ (posture 4). In both cases testing ended in apparent signs of fatigue due to isometric activity of the upper and the lower extremity muscles.

During ready position and shot somatic and vegetative parameters of the posture and formed motion were synchronously registered along with calculation of energy expenditures. Accuracy of target shooting was recorded.

Shifts of the body general centre of mass (GCM) while maintaining equilibrium in upright stance, tremor of the hand holding the pistol and accuracy of target shooting were considered as the parameters of the "final adaptive results".

Synchronous registration of somatic, vegetative and biomechanical indices followed by respective mathematical processing allowed to examine physiological mechanisms underlying interrelated activity of two systems of control, integrating for realization of the program of accuracy motion under various conditions. Methods of variance statistics including correlation, regression, dispersion, etc. methods of statistical analysis in STATISTICA system of Windows were applied for experimental material processing [4]. 


\section{Results of the research}

The results of studies have demonstrated that pistol holding in outstretched arm in shooter's specific stance insignificantly influences equilibrium stability: high equilibrium stability was observed in athletes both during convenient and specific posture of the shooter. Amplitude of high-frequency shifts of the body GCM varied from $0,6 \pm$ 0,09 to $0,8 \pm 0.03 \mathrm{~mm}$, whereas that of low-frequency - from $0,9 \pm 0,1$ to $1,6 \pm 0,16 \mathrm{~mm}$. Some somatic characteristics of the posture, activity of muscular and cardiovascular (CV) system showed significant changes both during ready position assumption and just before the shot.

For instance, standing with pistol in outstretched arm in shooter's specific posture while aiming was accompanied with significant increase of hand tremor amplitude relative to that in initial posture, and electric activity of brachioradial muscle (BRM), tendency to increase of electric activity of deltoid muscle (DM), enhancement of CV system activity and increased energy expenditures.

Just before the shot the character of posture regulation and hand voluntary motion control during aiming appeared to change: decrease of the amplitude of slow high-amplitude shifts of the body GCM was observed in frontal and sagittal planes, whereas fast ones - in frontal plane; besides, an increase of the frequency of fast vibrations of the body GCM and decrease of slow ones in sagittal plane, tendency to reduction of heart rate (HR), tremor amplitude (TA) of hand holding the pistol and amplitude of electromyograms (EMG) of BRM and DM were noted.

Coefficients of correlation $(r)$ between somatic parameters of the posture varied during ready position from $0,44 \pm 0,03$ to $0,738 \pm 0,0002$, reflecting different interdependence of the upper extremity muscle functioning, vibrations of the body GCM and tremor of hand holding the pistol. It is noteworthy, that in this case the dependence of $\mathrm{CV}$ system functioning and energy expenditure on somatic parameters of posture stability was also manifested. to enhance.

Just before the shot interrelation between somatic parameters of the posture and their correlation with HR tended

Sustained static tension of the upper and the lower extremity muscles while holding pistol in outstretched arm in complicated stance (with knee joint angle equal to $110^{\circ}$ ) induces more expressed shifts of the parameters of posture stability, muscular and cardiac activity, accelerates fatigue development and activates mechanisms of equilibrium correction in orthograde posture. The above is accompanied with synchronization of arm and the lower extremity vibrations, appearance of spike discharges of motoneurons on EMG and increase of energy expenditures, which finds its manifestation in high degree of correlations between parameters.

Improvement of the mechanisms of posture stability regulation and voluntary motion control in top level shooters is characterized by short-term decrease of EMG amplitude of deltoid and brachioradial muscles, tremor amplitude of hand holding the pistol and the main vibrations of the body GCM just before the shot.

Insignificant decrease of HR may be observed in some shooters in specific posture at the moment preceding the shot. Despite the fact that direct voluntary control for discrete involuntary vibrations of the body GCM is not possible (as according to N.A.Bernstein (2) their regulation is realized with participation of rubrospinal level of motion control), mechanisms of tremor amplitude, the body GCM vibrations and HR decrease are indirectly activated by top level athletes.

An artificial introduction of confounding factors (change of habitual posture, additional vestibular irritants, prolonged isometric regime of muscular activity) impairs the quality of posture regulation and is accompanied with increased energy expenditures and deterioration of shooting accuracy (Table 1).

Table 1

Somatovegetative indices and accuracy of shooting under different conditions of upright posture maintenance

\begin{tabular}{|c|c|c|c|c|}
\hline \multirow[t]{2}{*}{ Indices } & $\begin{array}{l}\text { Initial posture of } \\
\text { shooter }\end{array}$ & $\begin{array}{l}\text { Pistol holding until } \\
\text { fatigue }\end{array}$ & \multicolumn{2}{|c|}{$\begin{array}{l}\text { Low stance maintenance } \\
\text { until fatigue }\end{array}$} \\
\hline & $\begin{array}{ll}\mathrm{X} & \pm \mathrm{M}\end{array}$ & $\pm \mathrm{M}$ & $\mathrm{X}$ & $\pm_{\mathrm{M}}$ \\
\hline Tremor amplitude, $\mathrm{mm}$ & 7,5 & 0,27 & 10,9 & 1,6 \\
\hline $\begin{array}{c}\text { Sagittal stabilogram ampl., } \\
\text { mm }\end{array}$ & 0,1 & $1,78 \quad 0,14$ & 4,76 & 0,57 \\
\hline EMG of DM, mkV & $321 \quad 20,0$ & $382,9 \quad 25,0$ & 513,0 & 53,3 \\
\hline EMG of BRM, mkV & $232 \quad 17,6$ & $219,6 \quad 19,9$ & 295,3 & 17,9 \\
\hline EMG of QMT, mkV* & $74.6 \quad 1,4$ & $16,7 \quad 3,0$ & 221,1 & 9,2 \\
\hline EMG of GM, mkV & $74.6 \quad 3,4$ & $107,4 \quad 8,4$ & 184,2 & 14,4 \\
\hline HR, bt·min -1 & $92.8 \quad 1,7$ & $102,4 \quad 2,5$ & 111,2 & 3,2 \\
\hline
\end{tabular}




\begin{tabular}{|c|c|c|c|c|}
\hline \multirow[t]{2}{*}{ Indices } & $\begin{array}{l}\text { Initial posture of } \\
\text { shooter }\end{array}$ & $\begin{array}{l}\text { Pistol holding until } \\
\text { fatigue }\end{array}$ & \multicolumn{2}{|c|}{$\begin{array}{l}\text { Low stance maintenance } \\
\text { until fatigue }\end{array}$} \\
\hline & $\pm_{\mathrm{M}}$ & $\pm_{\mathrm{M}}$ & $\mathrm{X}$ & $\pm_{\mathrm{M}}$ \\
\hline Energy expenditure, kcal & $\begin{array}{ll}4.2 & 0,2\end{array}$ & 4,45 & 5,15 & 0,12 \\
\hline Shooting result (5 shots) & $49.4 \quad 0,29$ & $48,45 \quad 0,53$ & 46,74 & 0,91 \\
\hline
\end{tabular}

*EMG of QMT = electromyogram of quadriceps muscle of thigh; EMG of GM = electromyogram of gastrocnemius muscle.

Despite the fact that confounding factors (prolonged pistol holding in outstretched arm and low stance until fatigue) decrease posture stability, increase and synchronize various vibrations of standing person, more fit athletes damp down these vibrations before the shot, preventing their "spreading" on the arm holding the pistol. Unfit athletes do not possess this capacity, therefore the shot is made in the face of decreased equilibrium stability, increased TA of arm, EMG of DM and BRM, HR and energy expenditures, which leads to impaired shooting accuracy.

Correlation analysis has demonstrated that under complicated standing conditions (while holding pistol in outstretched arm until fatigue or keeping knee joint angle equal to $110^{\circ}$ ), interaction of functional systems of posture stability control and accuracy of voluntary motion tends to increase.

Analysis of interactions at the moment of ready position and just before the shot shows that control for posture stability, tremor vibrations of arm holding the pistol and HR at the moment preceding the shot, is dependent on the character of posture regulation during ready position (15-10 sec before the shot). This is evidenced by revealed high positive correlations, reflecting dependence of amplitude of the body GCM shifts, arm tremor, and EMG at the moment preceding the shot on respective indices registered during assuming ready position (Table 2).

Table 2

Interactions of somatic indices and HR of athletes-shooters, recorded just before the shot with analogous indices registered while assuming ready position

\begin{tabular}{|c|c|c|c|c|c|c|c|c|c|}
\hline \multirow{3}{*}{ 总 } & \multirow{3}{*}{\multicolumn{2}{|c|}{ Indices: }} & \multicolumn{7}{|c|}{ Before the shot: } \\
\hline & & & \multirow{3}{*}{$\begin{array}{c}\text { tremor } \\
\text { amplitude } \\
-0,725\end{array}$} & \multicolumn{3}{|c|}{ stabilogram } & \multicolumn{2}{|c|}{ EMG } & \multirow[t]{2}{*}{ HR } \\
\hline & & & & sag. $A_{1} *$ & fr. $F_{2}$ & fr. $A_{2}$ & $\mathrm{DM}$ & BRM & \\
\hline \multirow[t]{2}{*}{$\mathrm{R}$} & \multirow[t]{2}{*}{ tremor } & frequency & & & - & & - & - & $-0,770$ \\
\hline & & amplitude & 0,966 & & - & & - & - & 0,921 \\
\hline \multirow{4}{*}{$\begin{array}{l}\mathrm{a} \\
\mathrm{d} \\
\mathrm{y}\end{array}$} & \multirow{4}{*}{$\begin{array}{c}\text { stabilogra } \\
\mathrm{m}\end{array}$} & sag. $A_{1}$ & - & 0,605 & - & $-0,617$ & - & - & 0,654 \\
\hline & & sag. $A_{2}$ & - & 0,685 & - & 0,630 & - & - & - \\
\hline & & sag. $F_{1}$ & - & 0,751 & - & - & - & - & - \\
\hline & & fr. $F_{2}$ & - & - & $-0,778$ & - & & & - \\
\hline \multirow[b]{2}{*}{$\mathrm{o}$} & \multirow[t]{2}{*}{ EMG } & $\mathrm{DM}$ & - & - & & - & 0,878 & 0,898 & \\
\hline & & BRM & & - & & - & 0,898 & 0,918 & 0,748 \\
\hline S. & \multicolumn{2}{|l|}{ HR } & & & & - & & 0,748 & 0,789 \\
\hline
\end{tabular}

* Notes: sag. - sagittal, fr. - frontal, $\mathbf{A}_{1}$ - amplitude of high-frequency vibrations, $\mathbf{A}_{2}$ - amplitude of lowfrequency vibrations, $\mathbf{F}_{\mathbf{1}}$ - frequency of low-amplitude vibrations, $\mathbf{F}_{\mathbf{2}}$ - frequency of high-amplitude vibrations.

Correlation analysis results indicate that the greater are the arm TA while assuming ready position, the body GCM vibrations, muscle electric activity and HR (10-15 sec before the shot), the higher are their meanings just before the shot and vice versa. Fit athletes tend to manifest more expressed capacity for reduction of these vibration amplitude and HR decrease before the shot.

The less is the posture stability at the beginning of ready position, the more expressed are correctional reorganizations of posture just before the shot in athletes: high correlation interactions have been observed between amplitude of the body GCM and tremor while assuming ready position and the degree of their decrease just before the shot $(r=0,913<0,01$ and $r=0,717<0,01$, respectively), which is indicative of control on the basis of signals of negative feedback (2). 
At the same time, deterioration of equilibrium stability in sagittal plane while assuming ready position activates compensatory responses aimed at decrease of amplitude $(\mathrm{r}=-0,677 \pm 0,008)$ and increase of frequency $(\mathrm{r}=0,736 \pm 0,003)$ of tremor, rise in frequency of the main vibrations of frontal stabilogram $(r=0,623 \pm 0,02)$ just before the shot. Increase of amplitude of the main vibrations of the body GCM in frontal plane while assuming ready position leads to decrease of amplitude of deltoid muscle EMG $(\mathrm{r}=-0,669 \pm 0,009)$ just before the shot.

Analysis of regulation mechanisms of posture stability during ready position shows that programing of responses, which provide maximal accuracy of shooting in case of regular hindrances to posture maintenance, includes the development of efficient program anticipating posture reorganization, consisting in activation of motor units, stabilization of equilibrium and joint angle during ready position assumption and just before the shot, between the parameters of which and voluntary motion accuracy there exist high correlations.

The findings demonstrate that arm tremor depending on EMG activity of DM during ready position exerts the greatest influence on accuracy of shooting: there exist strong negative linear dependences between arm TA, electric activity of DM and shooting accuracy - the higher are arm TA and electric activity of DM, the lower is the result of shooting.

Presented in Fig.1 coefficients of correlation and determination, regression models reflect high dependence of the result of accuracy motion on posture somatic parameters recorded during ready position and just before the shot under ordinary and complicated conditions of standing: the higher is the amplitude of tremor, body GCM vibrations and electric activity of DM and BRM, the lower is the result of shooting, and vice versa.

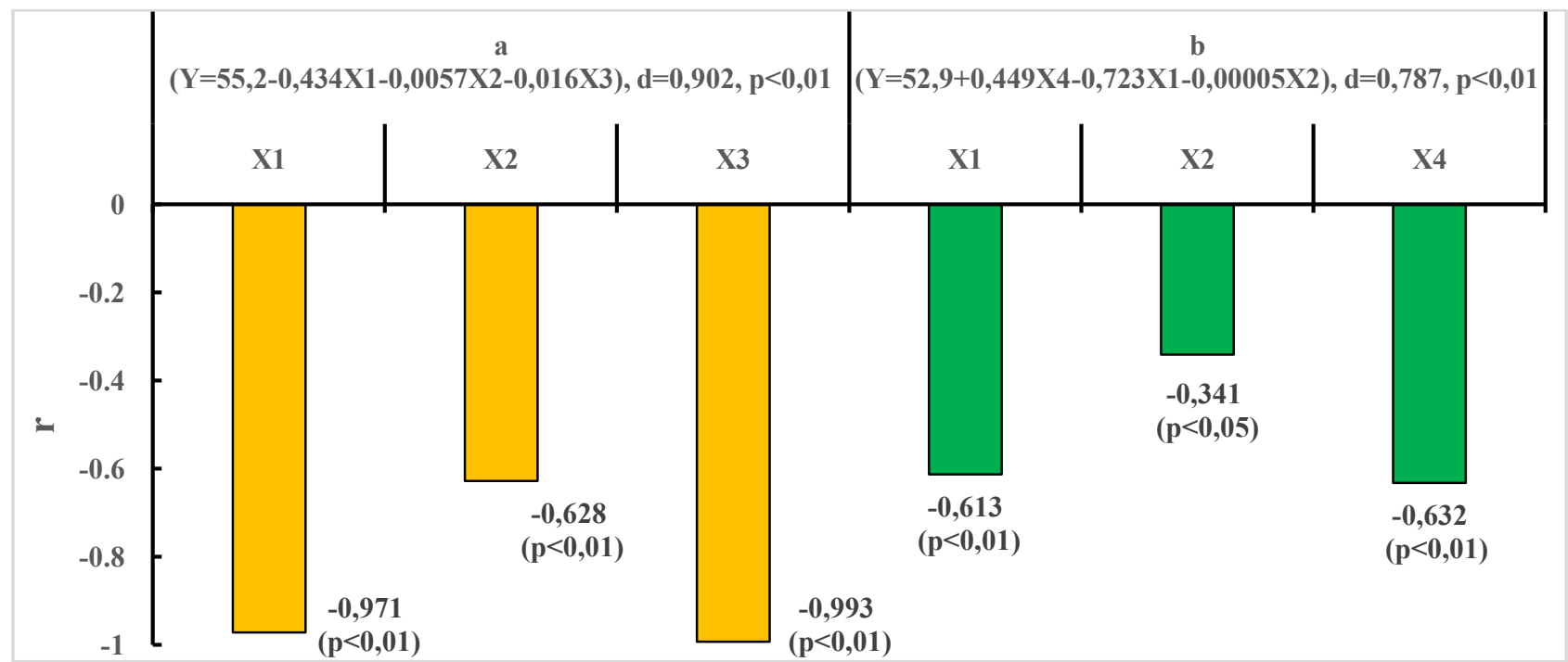

Fig.1. Coefficients of correlations and regression models reflecting association between accuracy of target shooting and posture somatic parameters, recorded during ready position (a) and just before the shot (b): $r-c o e f f i c i e n t s$ of correlation; $Y$ - result of shooting, points; X1 - tremor amplitude, $m m ; X 2-E M G$ of DM, mkV; X3 - EMG of BRM, $m k V ; X 4$ - amplitude of sagittal stabilogram, mm.

Coefficients of pair and multiple correlations, determination and regression equations indicate that accuracy of voluntary motion is determined not only by partial contribution of individual parameters of examined system but their interaction as well, as a result of which there occurs dependence, different in the degree and the form from pair correlations, which is approximated rather precisely by means of multiple regression equations presented in the Figure.

\section{Discussion.}

Carried out studies have confirmed the findings of several authors indicating close association between the parameters of shooter's upright posture stability and accuracy of target shooting $[6,7,14-16]$. Dependence of shooting accuracy on the peculiarities of cardiac activity has been also revealed, which corresponds to the results reported by several authors $[6,13]$.

At the same time, conducted studies have specificated the mechanisms of posture regulation while assuming ready position and just before the shot as well as their associations providing optimum background conditions for realization of voluntary accurate motion - target shooting.

For instance, it has been revealed that at the beginning of aiming the character of deviating posture regulation is manifested providing alteration of equilibrium stability control during the shot, depending on stability in ready position.

Statistical processing of findings has revealed rather strong influence of individual somatic characteristics of posture and their interactions upon the mechanisms of accurate volitional motion control during ready position and target shooting. This is also indicative of close interrelation of regulation mechanisms of two systems of control: the system of upright posture stabilization and that of voluntary motion. 
Analysis of coefficients of correlation, determination and regression equations, presented in Fig.1, demonstrates high degree of dependence of shooting accuracy on simultaneous interrelated impact of posture somatic parameters, of which the greatest influence on the result is exerted by relatively slow, low-frequency vibrations of the body GCM, sequacious to voluntary control. Top level athletes have a knack for damping them down, manifesting higher quality of posture stability control at the moment of accurate motion realization.

On the basis of obtained results it is safe to conclude that formed program of realization of forthcoming accurate motion includes both standard parameters of posture and voluntary motion and the mechanisms of correcting their interaction when confounding factors and hindrances are acting, thus providing control of perturbation and deviation.

As a result of the above, high accuracy during the shot is achieved in adapted athletes at well-timed (in accordance with created standard and the character of correctional inverse afference) preliminary posture reorganization - its stability and biomechanical parameters.

During fatigue in less adapted to physical load athletes, one may observe increase of amplitude and synchronism of vibrations of different body links in upright posture, loss of ability to damp down these vibrations, which are propagating to the barrel, thus deteriorating shooting quality the more, the higher are their amplitude and the degree of synchronization.

The worse posture stability at the beginning of ready position, the more expressed are its correctional reorganizations just before the shot: the more decreased are the arm TA, the body GCM vibrations; besides the tendency to HR reduction is observed. The above reflects deviation control on the basis of negative feedback.

Hence important tasks follow: a) elaboration of means and methods of posture stabilization during ready position, aimed at improvement of stability within equilibrium zone, decrease of amplitude of tremor, muscle electric activity, HR just before the shot; b) usage of prognostic models allowing to predict the system state, the character of posture control just before the shot and accuracy of voluntary motion realization on the basis of initial data.

\section{Conclusions.}

1.Obtained results reveal the mechanisms of functioning and interacting of two control systems - posture and voluntary motion.

2.High degree of shooting accuracy dependence on simultaneous interacting impact of posture somatic parameters has been revealed, of which the greatest influence on the result is exerted by relatively slow, low-frequency vibrations of the body GCM, sequacious to voluntary control.

3. Elaborated regression models permit to model and predict: 1) posture stability, the character of its regulation just before the shot depending on analogous parameters during ready position; 2) change of CV system activity at the moment of shot depending on posture stability, activity of muscles, tremor of arm holding the pistol during ready position and just before the shot; 3 ) accuracy of shooting depending on the character of posture regulation during ready position and the shot.

\section{References:}

1. Anokhin P.K. Ocherki po fiziologii funkcional'nykh sistem [Essays on the physiology of functional systems], Moscow, Medicine, 1975, 448 p. (in Russian)

2. Bernshtejn N. A. O postroenii dvizhenij [On the construction of movements], Moscow, Medicine, 1947, 255 p. (in Russian)

3. Bernshtejn N.A. O lovkosti $i$ ee razvitii [About dexterity and its development], Moscow, Physical Culture and Sport, 1991, 288 p. (in Russian)

4. Borovikov V.P., Ivchenko G.I. Prognozirovanie $v$ sisteme STATISTICA $v$ srede Windows [Forecasting in the STATISTICA for Windows], Moscow, Finance and Statistics, 2006, 275 p. (in Russian)

5. Bozerzhan Zh. Spravochnik po sportivnoj strel'be [Handbook of sports shooting], Rostov on Don, Phoenix, 2006, 192 p. (in Russian)

6. Ivanov K.O., Kubriak O.V. Vliianie oshchushchenij ot serdca i stabil'nosti pozy na tochnost' strel'by v predstavlenii elitnykh strelkov [Influence of feelings from the heart and stability pose on accuracy in the representation of elite shooters]. Vestnik sportivnoj nauki, 2011, no.5, pp. 13-22. (in Russian)

7. Kudelin A. Kak povysit' ustojchivost'? [How to improve stability?]. Oruzhie. 2005, no.2, pp. 64-66. (in Russian)

8. Prijmakov O.O. Vzaiemozv'iazok mekhanizmiv reguliuvannia stijkisti postavi ta svavil'nogo tochnist'n'ogo rukhu u sportsmeniv [Relationship resistance mechanisms regulating posture and arbitrary precision motion in athletes]. Fiziologichnij zhurnal. 1995, vol.41, no.3-4, pp. 23-28. (in Ukrainian)

9. Prijmakov A.A. Vzaimosviazi sistem regulirovaniia ravnovesiia v vertikal'noj stojke i upravleniia proizvol'nymi dvizheniiami u sportsmenov-strelkov [Relationship management systems of equilibrium in the vertical rack and control voluntary movements in athletes-riflemen]. Fizicheskoe vospitanie studentov. 2010, no.3, pp. 75-77. (in Russian)

10. Sudakov K.V. Funkcional'nye sistemy organizma [Body functional systems], Moscow, Medicine, 1987 , 432 p. (in Russian)

11. Tarasova L.V. Faktory ustojchivosti sistemy «strelok-oruzhie» v trenirovke vysokokvalificirovannykh strelkov [Resistance factors of the "shooter-weapon" in the training of highly skilled riflemen]. Vestnik sportivnoj nauki, 2009, no.3, pp. 25-27. (in Russian) 
12. Boloban V. Systemic stabilography: methodology of measuring, estimating and controling sportsman body balance and the system of bodies. Coordination motor abilities in scientific research. Biala Podlaska, 2005, pp. 102-109.

13. Christodonlou V.X., Dinas P.C., Baliamis N.G., Felouris A.D. Changes in heart rate variability during an archery competition. 15th annual congress of the European College of Sport Science: book of abstracts. 2010, no.15, pp. 339.

14. Era P., Konttinen N., Mehto P., Saarela P., Lyytinen H. Postural stability and skilled performance - a study on toplevel and naive rifle shooters. Journal of Biomechanics, 1996, vol.29, no.3, pp. 301-306.

15. Herpin G., Gauchard G.C., Lion A., Collet P., Keller D., Perrin P.P. Sensorimotor specificities in balance control of expert fencers and pistol shooters. Journal of Electromyography and Kinesiology. 2010, vol.20, no.1, pp. 162169.

16. Lakie M. The influence of muscle tremor on shooting performance. Exp. Physiol. 2010, vol.95, no.3, pp. 441-450.

17. Matthias E., Schandry R., Duschek S., Pollatos O. On relationship between interoceptive signal information and the process of visual stimulus processing. Int. J. Psychophysiol. 2009, vol.72, no.2, pp. 154-159.

18. Perrot C., Deviterne D., Perrin P. Influence of training on postural and motor control in a combative sport. $J$. Hum. Mov. Studies. 1998, no.35, pp. 119-135.

19. Terekhov A.V. Concerning the nature of slow component in postural sway. European Workshop on Movement Science. 2005, Vienna, 2005, 123 p.

20. Terekhov A.V., Levik Yu.S. The forming of the reference vertical in the orthograde posture stabilization task. Progress in motor control. 2006, no.5, pp. 4-20. 
Pryimakov 0.0.: http://orcid.org/0000-0003-0351-486X; aprim@bk.ru; Szczecin University; al. Piast 40B, Block 6, 71-065 Szczecin, Poland.

Eider Ezhy: http://orcid.org/0000-0002-8401-6442; sekretariat.wkfipz@ univ.szczecin.pl; Szczecin University; al. Piast 40B, Block 6, 71-065 Szczecin, Poland.

Omelchuk O.V.: http://orcid.org/0000-0001-6184-1362; omelchuk58@ mail.ru; M.P. Dragomanov National Pedagogical University; ul. Turgenevskaia 3-9, Kiev, 01000, Ukraine.

Cite this article as: Pryimakov A A, Fider E. Omelchuk EV. Stability of equilibrium in upright stance and voluntary motion control in athletes-shooters in the process of ready position and target shooting. Physical education of students, 2015, no.1, pp. 36-42. http://dx.doi.org/10.15561/20755279.2015.0106

The electronic version of this article is the complete one and can be found online at: http://www.sportpedu.org.ua/html/arhive-e.html

This is an Open Access article distributed under the terms of the Creative Commons Attribution License, which permits unrestricted use, distribution, and reproduction in any medium, provided the original work is properly cited (http:// creativecommons.org/licenses/by/3.0/deed.en).

Received: 12.11.2014

Accepted: 12.12.2014; Published: 30.12.2014 


\section{THE CHARACTERISTIC OF THE ENGINE QUALITIES OF THE STUDENTS OF TECHNICAL INSTITUTE OF III FUNCTIONAL HEALTH GROUP (SPECIAL MEDICAL GROUP) \\ Prosvirina L.N. ${ }^{1}$, Kolokoltsev M.M. ${ }^{1}$, Kolchanova M.A. ${ }^{1}$, Cieslicka Miroslawa ${ }^{2}$, Stankiewicz Blazej ${ }^{2}$ \\ National Research Irkutsk State Technical University, Russia ${ }^{1}$ \\ Kazimierz Wielki University in Bydgoszcz, Poland ${ }^{2}$}

Annotation. Purpose: the study of the dynamics of engine qualities in the students of III functional health group (special medical group) dependent on age taking into account the frequency of occupations by physical culture for the correction of the program of their physical training. Material: the physical condition is evaluated among 467 students at the age from 18 to 21 year. Observation is carried out in the dynamics of the instruction of students at the university from 1 through 5 semesters. Results: installed age characteristics of physical readiness of students, depending on the frequency of physical training. It is shown that the passage to the single-time in the week occupations by physical culture reliably decreases their physical condition. The features of the dynamics of the physical fitness of students. Conclusions: monitoring the physical fitness of students can be considered as a factor in strengthening the pedagogical orientation of physical education of youth. Should pay particular attention to the development of motor abilities missing with appropriate exercise. Students are encouraged to use the self-study managed to maintain the required physical condition, as well as the mandatory maintenance of a diary of self-control.

Keywords: student, university, physical, preparedness, monitoring, physical, culture.

\section{Introduction}

Leading problem of the present time is protection of human health. Modern society puts health, psychological comfort, high workability and healthy reproduction of on one of first places. Without solution of these tasks stable economic and political development of country, as well as social and cultural prosperity, are impossible [5, 7, 8].

Recent years attention to students' health has been increasing and its is connected with society's care of specialists' physical condition, with trouble of their morbidity in process of professional training and resulting workability $[1,2,4,20]$. Preservation of health of educational process's participants is one of important problems of higher professional education and of different branches in medicine. Against this background, seeking of ways for health improvement and increase of workability; increase of functional abilities and adaptation to training of future highly qualified specialists also become rather important $[3,12]$.

Many scientists regard physical education as significant factor I formation and rehabilitation of youth's health [3, 6]. In this case physical health is regarded as one of natural genetically programmed, non-medical and effective factors of youth's health improvement $[17,18,21]$.

At present time at physical culture lessons more individual evaluation of students' physical fitness is required, which would be the base of discipline "physical culture". It will permit to clearly understand weak sides of development of students' motion and functional abilities, to correct curriculums in HEEs and, thus, to weaken negative aspects of students' adaptation to new educational environment [9].

Variety of deviations in health condition, different levels of physical fitness of students set special requirements to physical culture in special health groups (SHG), which imply more individual approach to physical exercises [10]. In this connection there appears a task of working out and foundation of differential approach to selection of optimal loads, considering motivations to self-perfection in interconnection with students' psycho-emotional and motion specificities [7].

A number of authors $[4,5,6,8]$ note that it is necessary to control indicators of physical fitness as important component of children's teenagers and youth's health. In other countries this problem has been studied rather substantially $[13,14,15,16,19]$. However, characteristics of special health group students' motion abilities have not been studied completely.

\section{Purpose, tasks of the work, material and methods}

The purpose of the work: characterize age dynamic of girl students of special health group, considering frequency of physical culture training, for correction of physical culture training program.

Materials and methods: we tested 467 girl students (18-21 years old age) of National research Irkutsk state technical university, who were members of special health group (SHG). Our research was conducted in the course of girl students' studying from $1^{\text {st }}$ to $5^{\text {th }}$ semester $(01.10 .2011,01.05 .2012,01.10 .2012,01.05 .2013,01.11 .2013)$. For evaluation of girls' motion characteristics we used tests, worked out by All-Russia scientific-research institute of physical culture [11]. For evaluation of quickness we used test - 20 meters run (sec.); for strength and power endurance of girdle - hanging (sec.) and pressing ups (times); for speed endurance of muscles, bending torso, - torso rising (times); for flexibility - torso bending (cm); for dynamic strength of lower limbs - long jump from the spot (cm); for general endurance - 1000 meters run (minutes, sec.). Material was registered in special record of the research. By primary materials we formed computer data base; calculation of indicators was fulfilled with the help of applied programs «Statistica $6.0 »$.

(c) Prosvirina L.N., Kolokoltsev M.M., Kolchanova M.A.,

Cieslicka Miroslawa, Stankiewicz Blazej, 2015

http://dx.doi.org/10.15561/20755279.2015.0107 
We calculated mean arithmetic value of indicators (M), mean square deviation (s) and standard error (m). In our work we used parametrical methods of material's processing, considering normal Gauss distribution of quantitative characteristics in all age groups. Estimation of confidence of mean values of independent samples was carried out with Student's t- criterion. Differences between indicators with $\mathrm{P}<0.05$ were accepted as statistically confident.

\section{Results of the research}

Research during 5 semester permitted to determine that in test 20 meters from walking (see fig.1) there was improvement by the end of the research - from 3. $58 \pm 0.04$ to $3.49 \pm 0.04$ sec. $(\mathrm{P}<0.05)$.

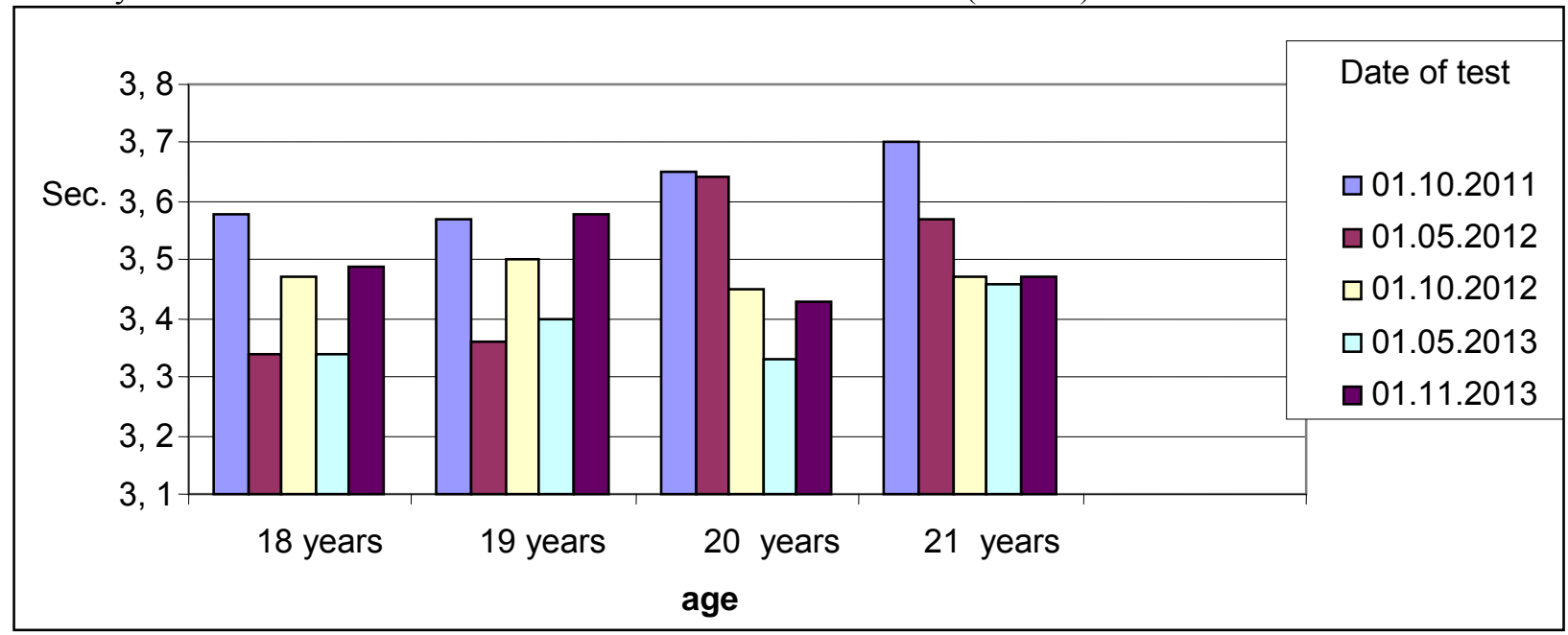

Fig.1. Dynamic of indicators in test 20 meters run from walking

In 19 years we registered improvement of this test result in 2, 3 and 4 semesters. With it, the best result was at the end of academic year of $2^{\text {nd }}$ semester $-3.36 \pm 0.03$ sec. However, by fifth semester we noticed significant worsening up to $3.58 \pm 0$. $06 \mathrm{sec}$. that approximately corresponds to $1^{\text {st }}$ semester's result. It, in our opinion, is connected with passing of $3^{\text {rd }}$ year students to "once a week" trainings.

20 years old girl students showed confident positive changes of the indicator by the end of $3^{\text {rd }}$ semester; test result improved from $3.64 \pm 0.04 \mathrm{sec}$. to $3.45 \pm 0.05$ (by $5.2 \%$ ); by the end of $4^{\text {th }}$ semester - up to $3.33 \pm 0.04$ sec. (by $8.5 \%$ ). Then there happens certain worsening of result up to $3.43 \pm 0.03 \mathrm{sec}$., and its is, probably, is connected with organization of "once a week" trainings of physical culture.

In older group (21 years) we registered rather high increment of results in this test. By the end of $2^{\text {nd }}$ semester it improved by $3.5 \%$ (from $3.70 \pm 0.06$ to $3.57 \pm 0.04$ ) and by $5^{\text {th }}$ semester - by $6.2 \%$ (up to $3.47 \pm 0.05 \mathrm{sec}$.).

In dynamic of general endurance (see fig.2) we did not determined positive results (test 1000 meter run). In our opinion it is connected with insufficient application of physical loads, oriented on development of this quality, in physical culture trainings.

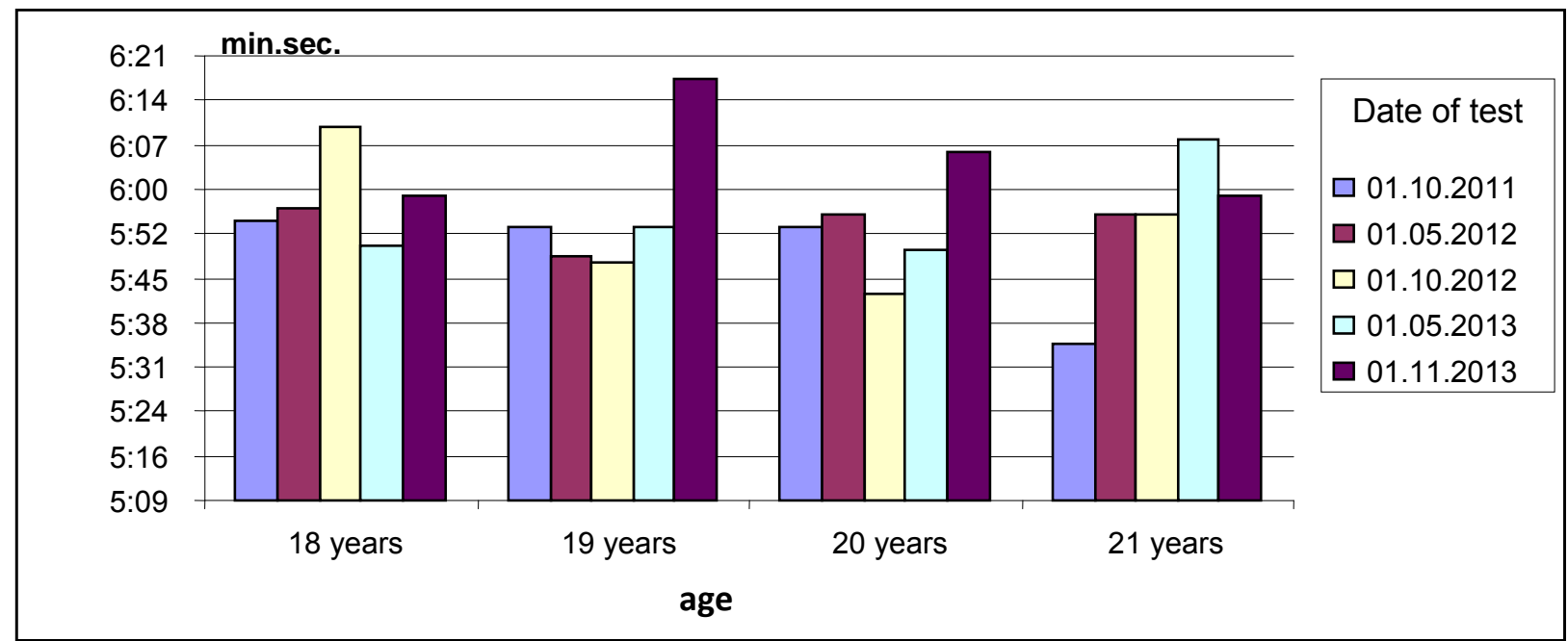

Fig.2.. Dynamic of indicators in test 1000 meters run 
In one of strength qualities (hanging on bent arms) we registered the most expressed positive dynamic of indicators, connected with frequency of physical culture trainings in HEE (see fig. 3).

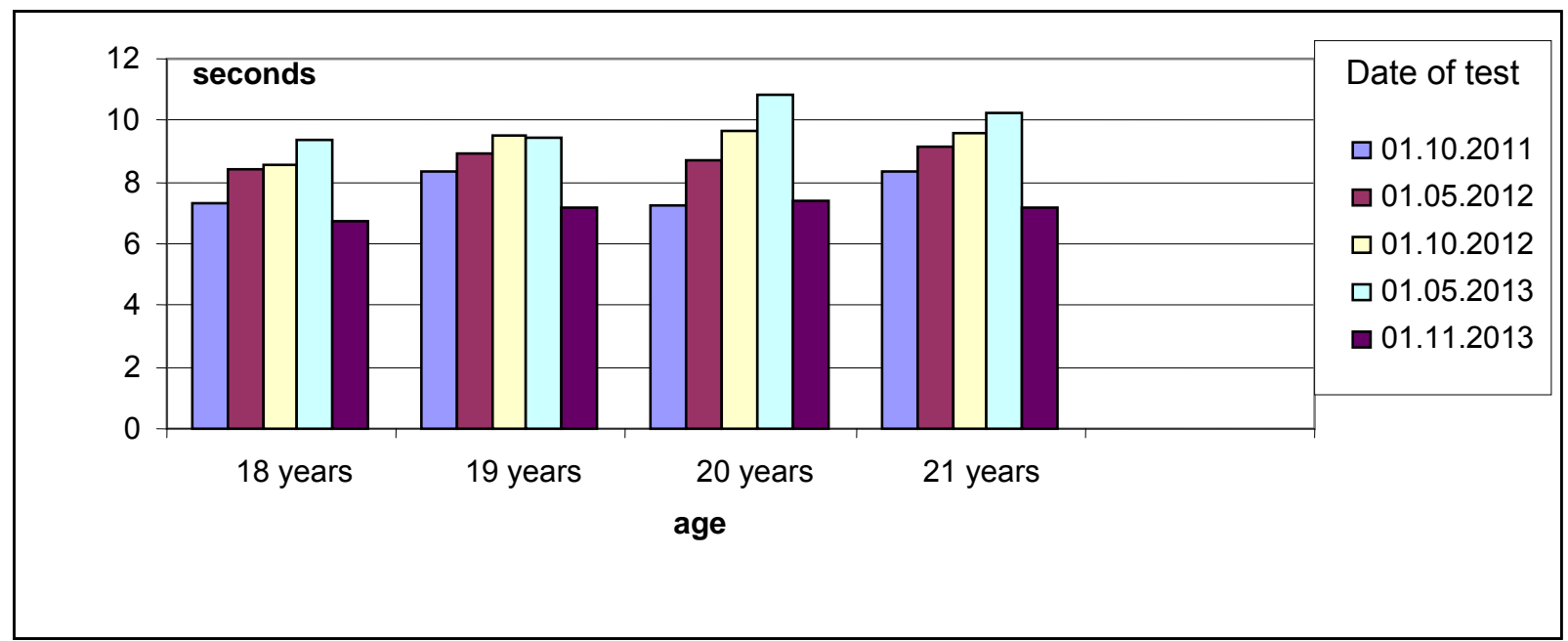

Fig.3. Dynamic of indicators in test "hanging on bent arms"

As it is seen in the figure in all tested age groups there was increment of indicator by May 2013, when girls were $2^{\text {nd }}$ year students and attended physical culture lessons twice a week. With passing to "once a week" trainings and after summer vacations (testing in November 2013) we registered confident reduction of test results in all age groups.

Approximately the same dynamic of indicators was registered in other power test - pressing ups (see fig.4).

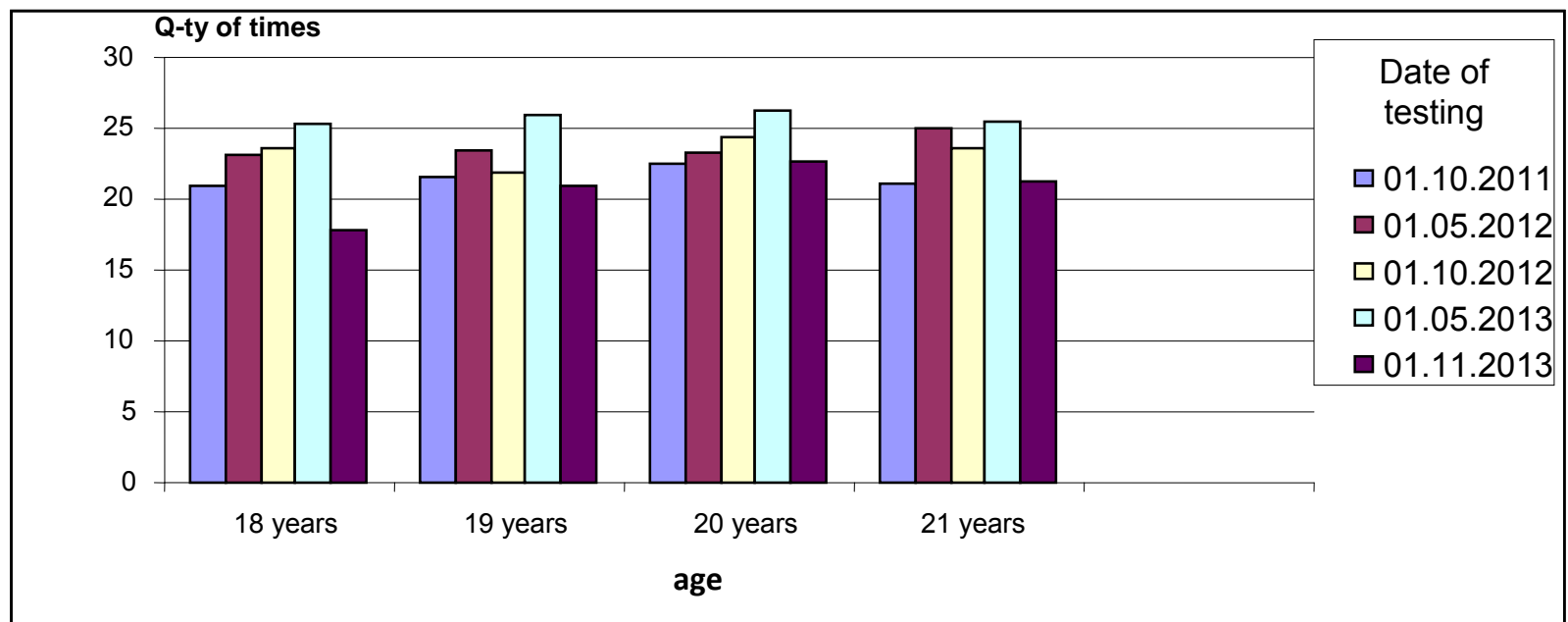

Fig.4. Dynamic of indicators in test "pressing ups"

In this test we registered confident increment of indicator in all tested ages, providing physical lessons were twice a week and reduction of results with passing to "once a week" lessons $(\mathrm{P}<0.05)$, (for third year students). Worsening of characteristics was registered by $41.9 \%$ in age of 18 years old (from $25.31 \pm 0.54$ to $17.83 \pm 0.58$ times) and by $18,8 \%$ in 19 years old age (from $24.94 \pm 0.65$ to $20.99 \pm 0.65$ times). In other ages reduction was not so significant - 9. 6-10.8\%.

In test "torso rising" during 30 seconds (see fig.5) we did not register positive dynamic in indicators. In our opinion the reason is weak condition of abdomen muscles, connected with insufficient using of appropriate exercises in discipline "physical culture". 


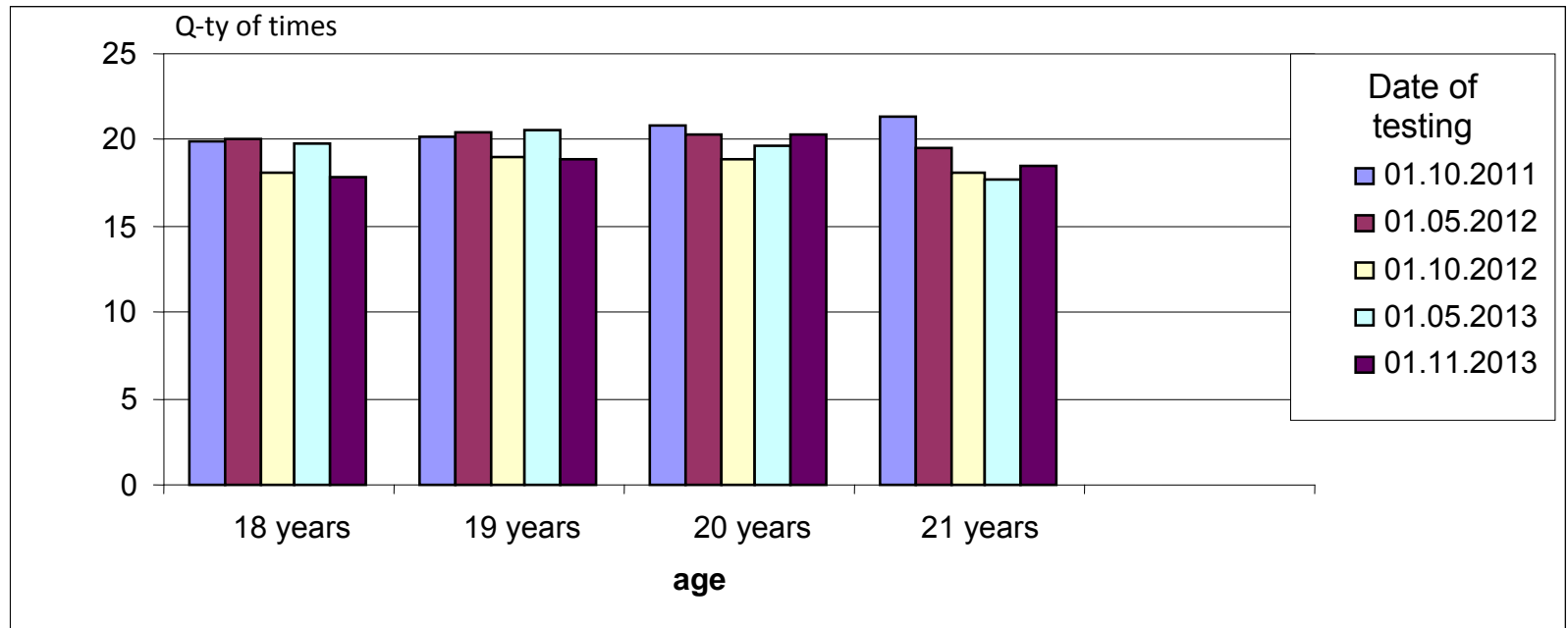

Fig.5. Dynamic of indicators in test "Torso rising during 30 seconds"

Graphs, illustrating flexibility are given in fig. 6 and 7.

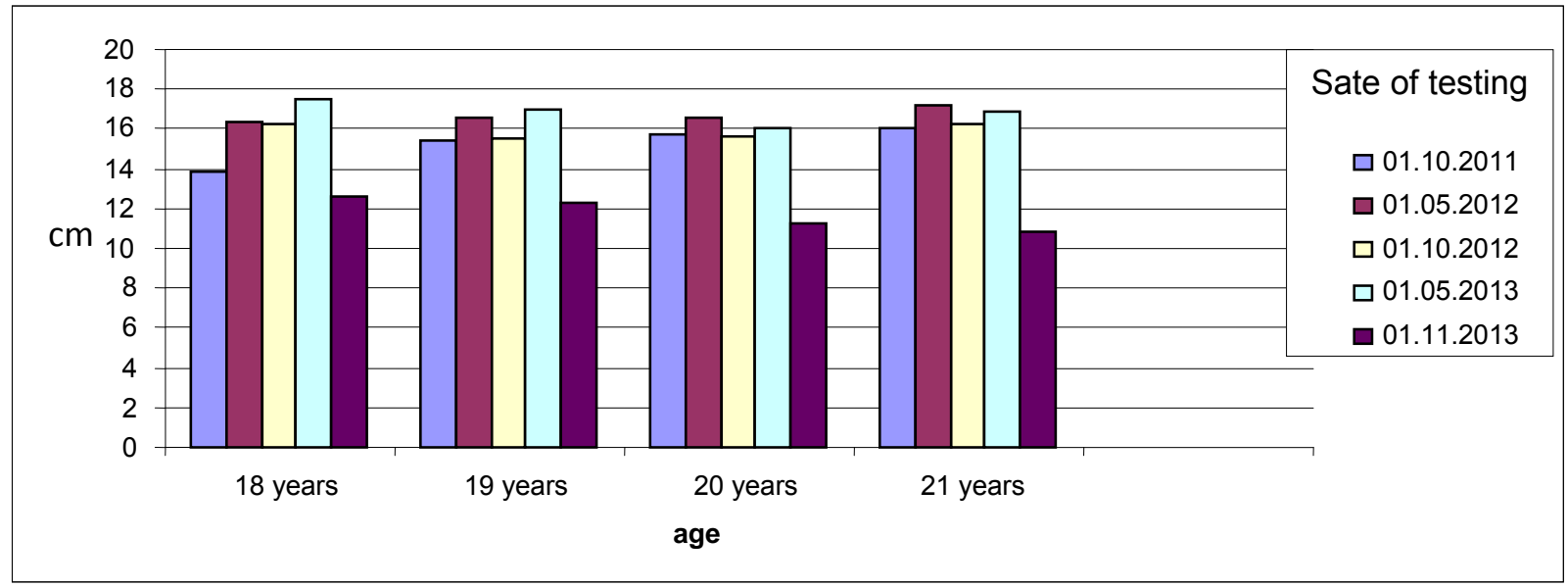

Fig. 6. Dynamic of indicators in test "Forward bending"

In these figures it is seen that in every age group there is confident dynamic: from first testing (October 2001) to May 2013 (when there were "twice a week" lessons. With passing to "once a week" lessons flexibility shows expressive dynamic of worsening in all age groups. With it, the highest reduction was registered in age 20 and 21 years old. It confidently reduced $(\mathrm{P}<0.05)$ in test "forward bending" in age 20 years old by $26.2 \%$, and in 21 years old age -35 . $9 \%$. In test "backward bending" from lying on abdomen position - by 19.5 and $24.4 \%$ (accordingly).

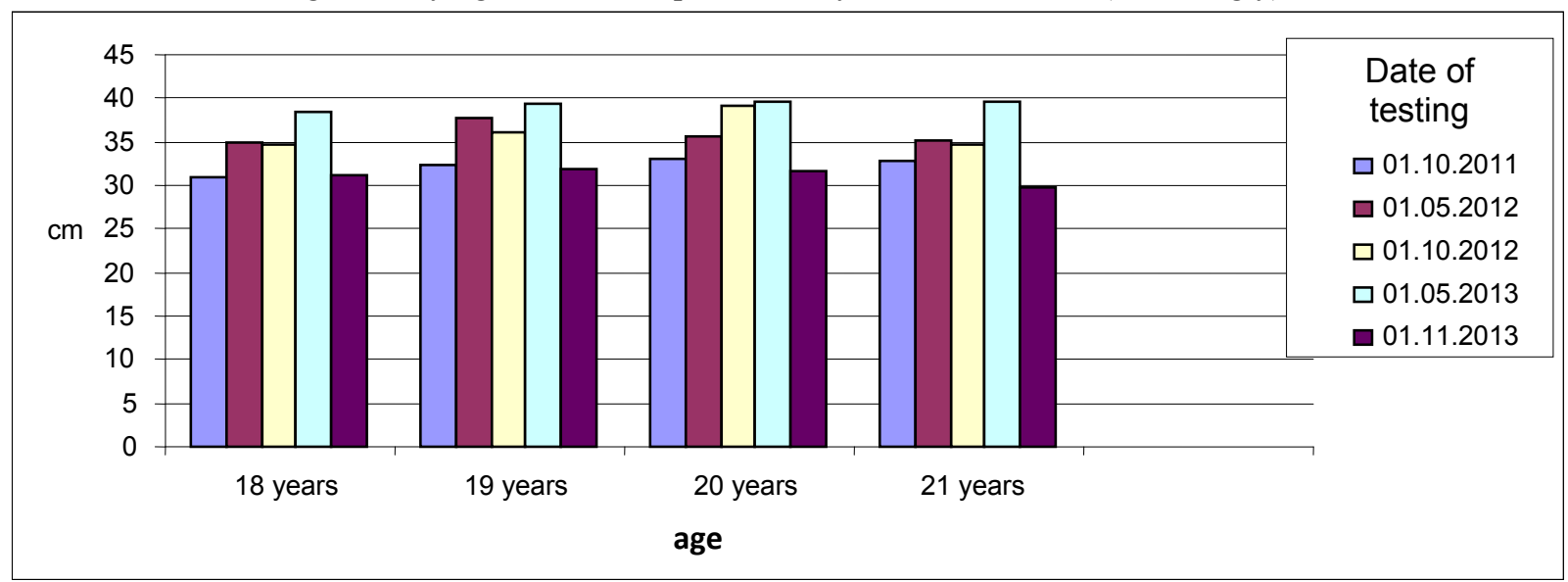

Fig.7. Dynamic of indicators in test "Backward bending from lying on abdomen position”. 
Dynamic of strength of lower limbs' muscles in test "long jump from the spot" is given in fig.8.

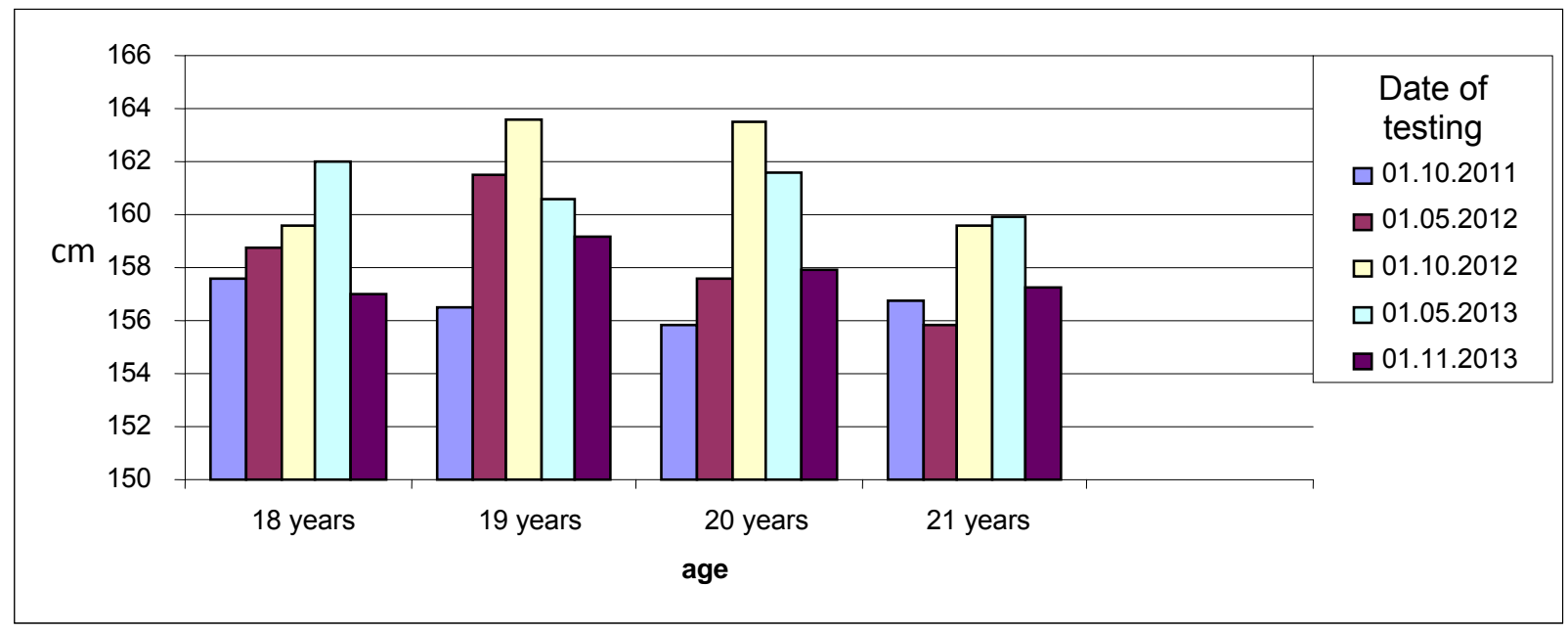

Fig. 8. Dynamic of indicators in test "Long jump from the spot"

We did not determine confident differences between indicators of all age girls with their testing in different dates. It can witness about insufficient effectiveness of used motion loads on lower limbs' muscles.

\section{Conclusions:}

1. Observation over age dynamic of physical fitness of special health group's girl students during 5 semesters permitted to determine positive dynamic in 5 from 8 motion tests by $5^{\text {th }}$ semester (with "twice a week" physical culture lessons). We did not register positive changes in general endurance of organism (100 meters' run), torso muscles' strength (test "torso rising during 30 seconds" and lower limbs (test "long jump from the spot").

2. With passing to "once a week" physical culture lessons (from $5^{\text {th }}$ semester) in all 8 tests we registered confident worsening of motion characteristics.

3. Monitoring of girl students' physical fitness can be regarded as a factor of increase of youth physical education's pedagogical orientation. The received results permitted to correct academic process; in particular to pay special attention to development of weak motion qualities with the help of appropriate physical exercises. Besides, with passing to "once a week" lessons it is recommended to use controlled independent trainings for maintaining of required physical condition with compulsory records in diary of self-control.

\section{References:}

1. Bakanova A. F. Formirovanie zdorovogo obraza zhiznedeiatel'nosti i problema individualizacii fizicheskoj podgotovlennosti studencheskoj molodezhi [Formation of healthy way of life and the problem of individualization of physical preparedness of students]. Physical Education of Students. 2012, no.1, pp. 8-12. (in Russian)

2. Bondarenko I.G. Opredelenie urovnia fizicheskoj podgotovlennosti studentov: dvigatel'nye testy i metod indeksov [Determining the level of physical preparedness of students]. Physical Education of Students. 2011, no.2, pp. 1013. (in Russian)

3. Borejko N.Iu. Razrabotka sistemy fizicheskogo vospitaniia dlia vysshikh tekhnicheskikh uchebnykh zavedenij [Development of physical education system for higher technical educational institutions]. Physical Education of Students. 2011, no.2, pp. 14-18. (in Russian)

4. Izaak S.I. [Scientific and technical project: monitoring of physical development and physical preparedness of children, adolescents and young]. Prioritety i perspektivy fizicheskoj kul'tury i massovogo sporta $v$ usloviiakh industrial'no-innovacionnogo razvitiia. Mat. konf. [Priorities and prospects for physical culture and sports in terms of industrial and innovative development. Conference]. Kazakhstan, Astana, 2013, pp. 171-174. (in Russian)

5. Kosolapov A.B., Lofitskaia V.A. Problemy izucheniia sokhraneniia i razvitiia zdorov'ia studentov [Problems of studying the preservation and development of students' health], Vladivostok, DVGAEU, 2002, 154 p. (in Russian)

6. Korolinskaia S.V. Nekotorye problemy adaptacii inostrannykh studentov anglijskogo otdeleniia NFaU [Some problems of adaptation of foreign students in the English Department of the University]. Physical Education of Students. 2011, no.4, pp. 48-51. (in Russian)

7. Lebedinskij V.Iu., Kolokol'cev M.M., Maslova E.S. Monitoring zdorov'ia sub"ektov obrazovatel'nykh processov v vuzakh [Health monitoring subjects of educational process in universities]. Irkutsk, Irkutsk State Technical University Publ., 2008, 268 p. (in Russian)

8. Semenov L.A. Monitoring kondicionnoj fizicheskoj podgotovlennosti $v$ obrazovatel'nykh uchrezhdeniiakh [Monitoring conditional of physical preparedness in educational institutions]. Moscow, Soviet sport, 2007,168 p. (in Russian) 
9. Solov'ev V.N. Adaptaciia studentov $k$ uchebnomu processu v vysshej shkole. Dokt. dis. [Adaptation of students to the educational process in higher education. Dokt. Diss.]. Izhevsk, 2003, 46 s. (in Russian)

10. Smirnov I.Iu. Fizkul'tura dlia special'noj medicinskoj gruppy [Physical education for special medical group]. Kostroma, Kostroma State Technological University Publ., 2012, 51 p. (in Russian)

11. Tiapin A.N., Puzyr' Iu.P., Zakharov L.A. Fizkul'turnyj pasport [Physical culture passport]. Moscow, 1998,25 p. (in Russian)

12. Shporin E.G., Lebedinskij V.Iu., Kolokol'cev M.M. [Monitoring the physical condition of students as an analytical database forming their healthy lifestyle]. Studencheskoe sportivnoe dvizhenie: Sostoianie, problemy i perspektivy razvitiia. Mat. mezhd. nauch.-prakt. konf. [Student sports movement: Status, problems and development prospects. Conference]. Krasnoyarsk, 2013, p. 479. (in Russian)

13. Abdullah A.S.M. Factors related to non-participation in physical activity among the students in Hong Kong. International Journal of Sports Medicine, 2005, vol.26, no.7, pp. 611-615.

14. Booth M.L. Assessment of physical activity: an international perspective. Research Quarterly for Exercise \& Sport, 2000, vol.71,no.2, pp. 114-120.

15. Fontes A.C.D, Vianna R.P.T. Prevalence and factors related to low level physical activity among university students in a public university in the northeast region of Brazil. Revista Brasileira de Epidemiologia, 2009, vol.12, no.1, pp. 20-29.

16. Haase A. Leisure-time physical activity in university students from countries: associations with health beliefs, risk awareness and national economic development. Preventive Medicine, 2004, vol.39, pp. 182-190.

17. Harkins S.W. Relationship between central and autonomic nervous system activity: Correlates of psychomotor performance in elderly men. Experimental Aging Research, 1976, vol.2, no.5, pp. 409-423.

18. Jorgensen M.M., Zachariae R. Autonomic reactivity to cognitive and emotional stress of low, medium, and high hypnotizable healthy subjects: Testing predictions from the high risk model of threat perception. International Journal of Clinical and Experimental Hypnosis, 2002, vol.50, no.3, pp. 248-275.

19. Musharrafieh U. Determinant of university students physical exercise: a study from Lebanon. International Journal of Public Health, 2009, vol.53, no.4, pp. 208-213.

20. Prusik Krzysztof, Prusik Katarzyna, Iermakov S.S., Kozina Zh.L. Indexes of physical development, physical preparedness and functional state of polish students. Pedagogics, Psychology, Medical-Biological Problems of Physical Training and Sports. 2012, no.12, pp. 113-122.

21. Quennerstedt M. Exploring the relation between physical activity and health - a salutogenic approach to physical education. Sport, Education and Society. 2008, vol.13, no.3, pp. $267-283$. http://dx.doi.org/10.1080/13573320802200594 
Information about the authors:

Prosvirina L.N.: http://orcid.org/0000-0002-2196-7400; mihkoll@mail. ru; National Research Irkutsk State Technical University; 83, Lermontov street, 664074, Irkutsk, Russia.

Kolokoltsev M.M.: http://orcid.org/0000-0001-6620-6296; mihkoll@ mail.ru; National Research Irkutsk State Technical University; 83, Lermontov street, 664074, Irkutsk, Russia.

Kolchanova M.A.: http://orcid.org/0000-0001-9775-4236; makolchanova@gmail.com; National Research Irkutsk State Technical University; 83, Lermontov street, 664074, Irkutsk, Russia.

Cieslicka Miroslawa: http://orcid.org/0000-0002-0407-2592; cudaki@ op.pl; Kazimierz Wielki University in Bydgoszcz; Chodkiewicza str. 30, 85-064 Bydgoszcz, Poland.

Stankiewicz Blazej: http://orcid.org/0000-0001-6743-1073; blazej1975@interia.pl; Kazimierz Wielki University in Bydgoszcz; Chodkiewicza str. 30, 85-064 Bydgoszcz, Poland.

Cite this article as: Prosvirina L.N., Kolokoltsev M.M. Kolchanova M.A., Cieslicka Miroslawa, Stankiewicz Blazej. The characteristic of the engine qualities of the students of technical institute of III functional health group (special medical group) Physical education of students, 2015, no.1, pp. 43-49. http://dx.doi. org/10.15561/20755279.2015.0107

The electronic version of this article is the complete one and can be found online at: http://www.sportpedu.org.ua/html/arhive-e.html

This is an Open Access article distributed under the terms of the Creative Commons Attribution License, which permits unrestricted use, distribution, and reproduction in any medium, provided the original work is properly cited (http:// creativecommons.org/licenses/by/3.0/deed.en)

Received: 27.11.2014

Accepted: 27.12.2014; Published: 30.12.2014 


\title{
LAW ENFORCERS RECOGNITION LEVEL EMERGING THREATS BASED ON PHYSICAL APPEARANCE AND BEHAVIOR SIGNS THE ENEMY
}

Radzievskiy R.M., Plisko V.I.

Chernigov National Pedagogical University

\begin{abstract}
Annotation. Purpose: examine the effectiveness of the training method of differential approach to the choice of means of influence on the action of law enforcers opponent with different levels of aggressiveness. Material: the experiment involved 15 students of the Kyiv National Academy of Internal Affairs and the 15 employees of the State Guard of Ukraine. Results: presented curriculum for special physical and tactical training. The program details the conceptual apparatus of THREATS and DANGERS manifestations of different levels of aggressiveness opponent (case analysis of its motor behavior). The study participants underwent 7 day course focused training. The basis of the course is an advanced theoretical base. The base is aimed at developing knowledge and skills of employees in determining the level of danger. Including threats from testing and modeling episodes of extreme situations the options cadets. Conclusions: In the simulated collision situations with aggressive opponent to the students significantly improved the adequacy of the response to the threat of execution time and within the legal grounds. Recognition was determined by the level of aggressiveness manifest manners enemy, his emotions, motivation, motor behavior, positional arrangement for 2 - 3 seconds. The program contributed to the development of qualities: attention, orientation, perception, motor lead.
\end{abstract}

Keywords: law enforcement, enemy, choice of actions, motor behavior, aggression, danger, threat.

\section{Introduction}

Analysis of law officers' functioning in condition of fight with adversary showed their relatively weak fitness for such situation. Rather often wrong decisions, incomplete understanding of situation, in respect to different levels of threat result, in law officers' inadequate response that, in its turn, leads to problem of uncompleted conflict.

As a result law officer are often wounded, receive different traumas or, on the contrary, are brought to justice for exceeding limits of physical influence, resulting in legal consequences. The mentioned by us problem shows at importance of its decision because it concerns law officers' resistance to different dangers.

In the course of our research we found the problem of weak self-identification by law officers in such situations and the sense of this problem is that physical education and special-tactic academic programs do not include such directions as mastering of knowledge and skills in recognition of threats, dangers by a number of behavior, external motion signs of adversary.

Analysis of works, fulfilled by specialists in professional training of law officers showed their one-side approach to solution of studied problems. For example, in field of special physical training they are regarded in respect of development of own special, physical and mental qualities, without training of skills in perception and evaluation of external threats and dangers (Anufriyev M.I., Babenko V.G. [9], Bondarenko V.V. [13], Bulachek V.R. [6], Butov S. Ye., Viniarchuk I.S., Gida O.F. [8], Yosypiv Yu.R., Zakorko I.P. [10], Popov O.V., Reshko S.M., Yanko I.V., Belur J. и соавторы [21], Dean G. et al. [22], Heinonen A. et al. [25], Royds D. [26], Ryan B.J. [27], Semukhina O. [28], Thomassen G. [29], Walker S. [30]).

In the same way psychologists (Shoygu Yu.S. [7], Gurenkova T.N., Smirnov B.A., Dolgopolova Ye.V. [11], Yevsiukov O.P. [12], Liefterov O.V. [14]) do not give any estimation of motion responses to danger. Like jurists (Artamanova G.K. [15], Kartashov V.N. [16], Kazakov Yu.N. [17], Derkach A.A., Zazykin V.G. [18], Dmytrenko I.A. [19], Atrekozov V.G. [20]; Dean G., Fahsing I.A., Gottschalk P. [23]; Glomseth R., Gottschalk P., Solli-Sæther H. [24]), give recommendations for already happened situations in compliance with clauses of criminal code.

At the same time the moment of fight with armed (aggressive) adversary is still important for law officer, especially his ability to very quickly (during 2-3 seconds) evaluate situation and take decision what to do. Also it is important to timely respond to adversary with minimal risk for himself and other people, functioning in legal field.

The mentioned requirements can be defined as insufficiently solved problem. That is why it requires new approaches to working out of more perfect methodic for law officers' professional training.

Purpose, tasks of the work, material and methods

The purpose of this article is to analyze law officers' functioning in choosing adequate to danger or threat means. The tasks:

1. Studying, analyzing and widening of theoretical part of law officers' training for different conditions, connected with threats and danger.

2. To experimentally ground effectiveness of training for determination of threats' motion signs.

Main experiment was carried out with cadets ( $n-30$ человек) of Kyiv National academy of home affairs as well as with military officers of Governmental security of Ukraine (Kyiv). For testing of data, received in theoretical part we used pedagogic testing and simulation of extreme situation by method of scientific experiment.

Mathematical processing of results of the research permitted to determine a number of indicators, which facilitate strengthening of law officers' fitness.

\footnotetext{
(c) Radzievskiy R.M., Plisko V.I., 2015

http://dx.doi.org/10.15561/20755279.2015.0108
} 


\section{Results of the research}

Training of cadets for positive solution of conflict situations with aggressive adversary requires knowledge about their typical character, multiplicity of variants, conditions, with which they can meet in reality. And in compliance with virtual situation cadets shall be able to compare own abilities to fulfill tasks in conditions of different threats. So it was necessary to form ability to determine the level of sudden threat as quick as possible and adequately respond to it.

Manifestation of sudden threat usually takes from 1 to 3 seconds. It is difficult to train law officers to adequately respond to such threat during so short period and to form their appropriate skills. Every non standard situation has own specific signs of threat. It is necessary to determine these signs by adversary's behavior or movements and create general algorithm with certain deviations with certain parameters. Training process shall not be reduced to seeking of regularities and their determination shall be realized by typical signs of one or another threat considering sense of time.

In working out of modern methodic the newest is formation of skills to determine one or another threat in minimal time with simultaneous responding to it [1].

It should be realized that this methodic does not include threats of natural disasters, fires and so on. In this methodic only subject-to-subject functioning is regarded. With it one should differentiate defense of law officer's safety and defense of human right of a person with, whom law officer comes in contact, fulfilling his duties.

Special course of cadets' training to realize threat or danger is conducted in compliance with corrected program in several stages: 1) mastering of theory; 2) formation of ability to percept situation in the whole; 3) formation of knowledge about motion behavior and other signs of adversary; 4) choosing of actions in conditions of simulated situations. To effectively act in practice it is necessary, first of all, to open sense of main variants of actions, their characteristics [5]. We understand general idea in the following way:

Movements are purposeful and forced manifestation of human motion functioning, conditioned by fulfillment of certain tasks depending on purposes and environment;

Motion functioning - is level of manifestation of motion abilities and skills;

Sense-situational task - is mentally realized and consciously taken decision about fulfillment of purposeful movements in compliance with situation, considering safety of these movements and their efficiency and legal character;

Motion task - is requirement to fulfill certain movements with pre-set bio-mechanical characteristics for achievement of target;

Situational action - is manifestation of sense and motion functioning of a person, directed to seeking of solution of certain situational task;

Control - (informational-psychological structure) is ensured by such functional activity of nervous system, which results in formation of person's motive and target of action. On the base of processing of information about environment operative image of action is constructed (conceptual model), decision is taken, check up of results and correction of functioning is fulfilled.

Threat shall be understood as such behavior of adversary, which, by its characteristics, can bring potential or direct risk for health and life of law officers and other people.

To determine actions by level of threat, level of danger and conditions of their appearing it is necessary to base on general definitions.

Manifestations of levels of threat are as follows: obvious, potential, hidden, spontaneous, absence of threat.

Obvious threat - is registered adversary's physical actions directed against law officer or other person (including action, which can result in irreversible after effects).

Potential threat - is demonstrative aggressive behavior of armed (not armed) adversary without attempts to realize threat in practice. But in case of non-professional behavior of law officer this threat can become obvious (come in previous rank).

Hidden threat: with general tension in subject's behavior aggressiveness is not visible, flexibility is possible. But in specific conditions risk of attack is not excluded.

Indirect threat behavior and actions are not aggressive, but with it they are not controlled. Confusion can be caused by appearing of law officer. Avoiding from contact with law officer is possible.

Spontaneous threat - is uncontrolled behavior of some group, which can cause violation of public order.

Absence of threat is character of situational events between law officers and people, who manifest no threat (though situation is tensed).

Levels of danger are as following: high, middle, low and absence of danger.

High level: situational actions with high dynamic, oriented on traumatizing of vital human organs.

Middle level: physical actions, which can result in serious damage of functionally important human organs.

Low level: physical efforts as a response to external counter action and which can not damage human organs or parts of body.

Absence of danger: in conditions of tensed situation there are no pre conditions to any physical actions or counter actions. analysis:

Besides, the trainees were offered main characteristics of preparatory and attacking actions, as well as their

- Kinds of actions: attacks, counter actions, hidden-aggressive, provoked, neutral. 
- Attacks: initial aggressive physical actions with application of different objects, with clear amplitude of movements and which are directed to damaging of certain target.

- Counter actions: physical resistance with different amplitude of movements, with the help and without help of objects in response to actions of "irritator".

- Hidden-aggressive actions, with which amplitude of actions does not point at any aggressiveness. But in favorable conditions of situation there can appear aggressive action directed to achievement of target.

- Provoked actions are motion response to behavior of "irritator" with inadequate manners.

- Neutral actions: actions with character of expectation without any aggressiveness (though in tensed situation).

Means of attack: actions with clear amplitude of movements (straight, from side, from back); actions with hidden amplitude of actions (straight, from side, from back); with different objects and different angles of attack.

Characteristics of attack with clear amplitude of movements are the following: preparatory actions; movements with object (weapon); angle and direction of trajectory of threatening movement by temp, speed, inadequacy, purposefulness. Attack can be from the spot, in walking, frontal or from back, from side. With it direction of adversary's motion can be different.

Characteristics of attacking movements with hidden amplitude: preparatory movements do ot show possible attack, presence of any object in hand or its seizing is not visible, distance to targe6t can be rather short. Movements are fulfilled mainly from the spot in one direction.

After familiarizing with general conceptions on this topic the trainees shall enlarge knowledge on specificity of actions' manifestation, their determination, purposefulness, their legal limits and responsibility. It will permit to evaluate actions themselves in differentiated way.

Constructions of diagrams - models significantly deepen sense order of threats and dangers. It significantly enriches theoretical part of special training course.

For holistic perception of actions in extreme conditions the trainees were offered schematic models, their variant by levels of threat, danger, by means of their realization (see figs. 1,2).

Analysis of every component in the proposed diagrams give trainees better understanding of interconnections between behavioral characteristics, environment and situational conditions, in compliance with danger's or threat's level.

One of methods of threat's (danger) recognition by law officer is his ability to percept situation. In its base there is working out of certain skills.

Perception of situation is an informational-analytical process, in which system of analyzers and receptors of a person play important role. Such qualities as attention and power of observation help to manifestation of threat even during 1 second. It permits to timely respond to direct threat. With sudden situational threat visual analyzer restricts perception of space; all attention is directed to danger. It substantially hinders from objective and tactic analysis of situation. Adaptation (habit) can be formed in conditions of constant trainings, in which formation of skills goes simultaneously with analysis of threat's level and environment.

It pre conditions further actions of law officer. It is purposeful to train visual analyzer without using of other analyzers (in such conditions visual resource increases). In practice, in conditions of darkness or twilight healing analyzer is engaged to larger extent. . With developed (trained) hearing analyzer there is opportunity to distinguish kind of arm, with which shot was fulfilled, or other sounds (resembling shots).

Undoubtedly, positive result is achieved with ability to be ahead of adversary, resulted from recognition of threat [3]. For this purpose one shall have knowledge about adversary's behavior and act selectively (in the frames of legal field). Acquiring of knowledge of main space-time motion parameters, characteristics and manner of adversary's behavior will permit to accentuate attention on development of qualities, which can ensure motion domination. The acquired motion skills permit to quicker orient in situation by time, to recognize obstacles and prognosticate actions. With respect to adversary's actions behavior can be: motivational, aggressive, forcing, defensive, expressive. In specialists' opinion, there can be no previously planned crimes without motives. But by mentality not every person is able to shoot and kill other person [3]. 


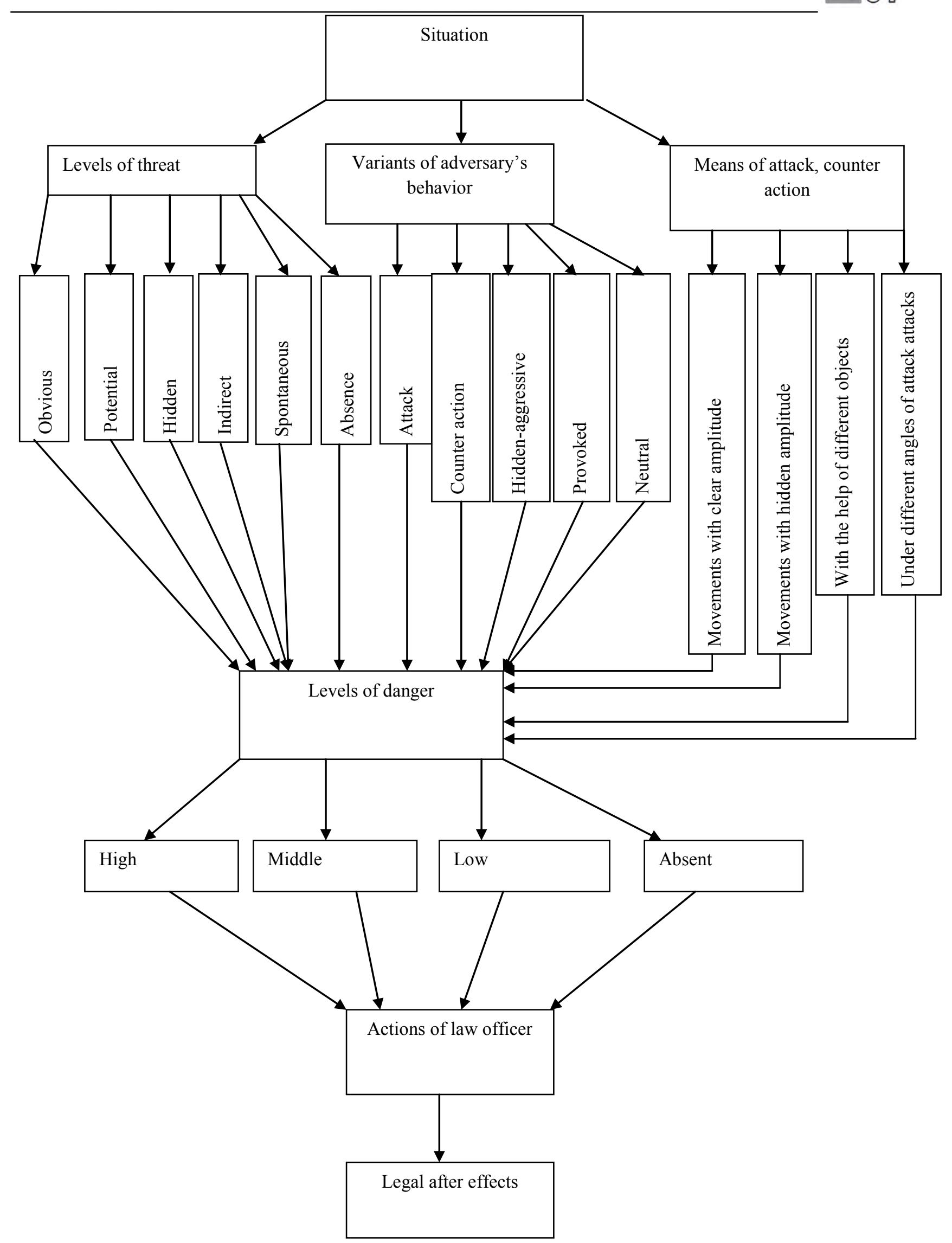

Fig. 1 Variants if levels of threat and danger according to situations 


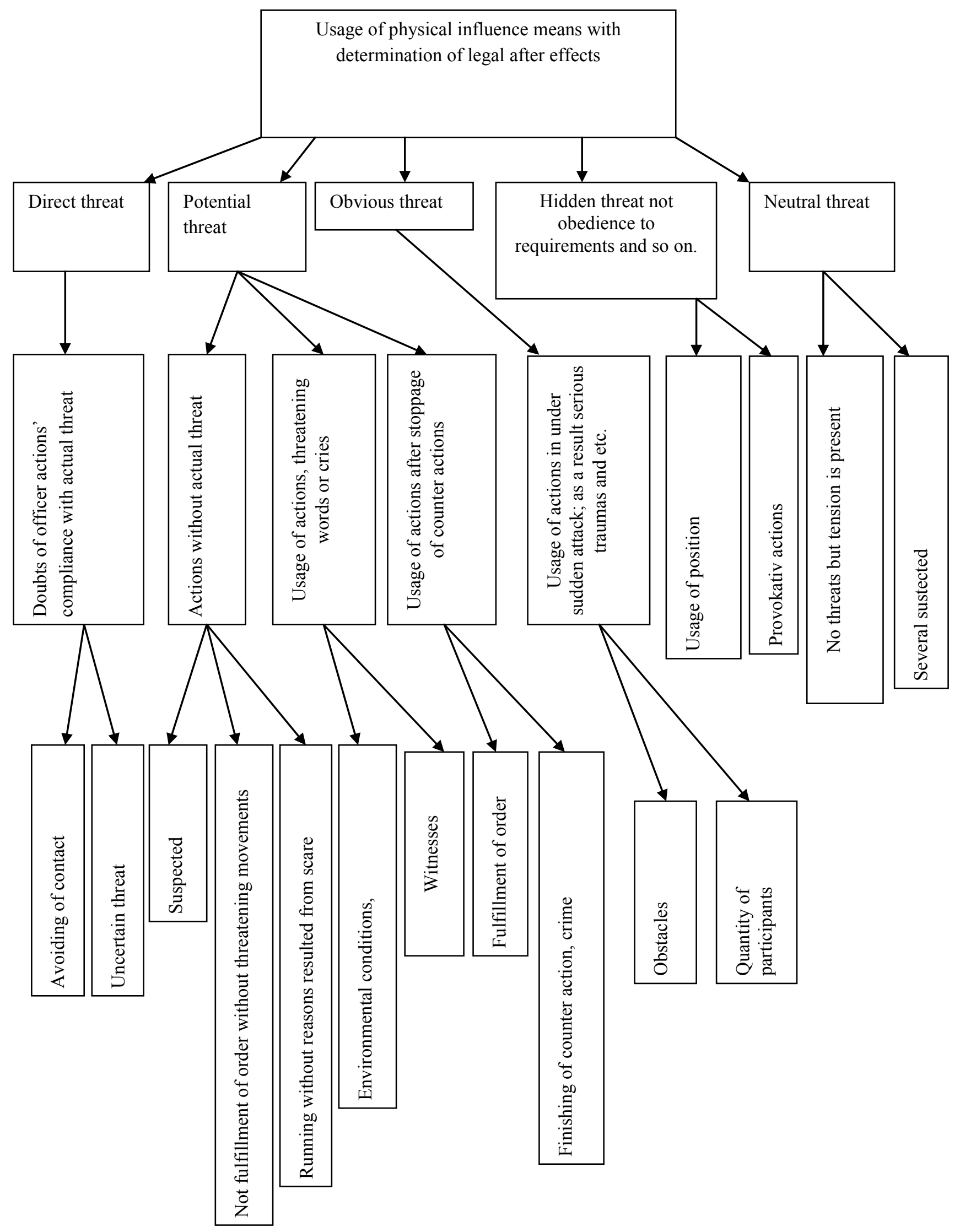

Fig.2. Determination of legal after effects in conditions of danger of different levels 
Training based on simulation of situations is a complex process, which stipulates coordination, accordance of actions of all participants. Purpose of simulation shall be compulsory determined. General tasks are set in compliance with this purpose. Then specific functional tasks for every participant are formulated. It should be noted that even insignificant deviation from actual actions' or behavioral criteria (which are simulated) can prevent from achieving of purpose. After simulation of situational episode brief conclusions about achievement of purpose are made. Simulation of situational episodes it is purposeful to conduct in conditions of different threats; it is necessary to create sudden situations with aggressiveness of different level. With it all participants shall not be previously informed about following actions. It can be simultaneous demonstration of situational episode. Besides, changes, in case of trainee's untimely actions, are possible. I.e. there is free transition to other motion action, manners and so on. With simulation of situations it is necessary to avoid excessive fantasy. For simulation situations, which happened in reality, can be used [2].

After seven days special training course we conducted experiment, in which 30 persons participated (control group - CG) and 30 persons - experimental group (EG). The participants were in equal conditions: during period of testing every of them was put three questions. The questions were not repeated; participants had no opportunity to know them beforehand. In total we prepared 90 questions, equal for both groups. With it we used method of pedagogic testing [3].

Simulation of episodes of sudden extreme situations took place in gyms and conference halls. We chose 10 episodes. All they were unknown for participants. Every participant took part only in one episode. With simulation w used method of scientific experiment [4].For example: situations simulated behind curtains. With its opening participant appears. In front of him a person lies; the second bent over him, the third runs away. Participant is offered maximum 3 sec. for solution of this task.

In other case, by composed previously scenario-dialogue (violator and his victim) conflict was played. Deviation from scenario was admitted and at some moment play became "free". But it continued without application of physical force. At the height of dialogue the third party intervened - law officer, who arrived at the place of event. "Victim" obeyed orders of law officer. Behavior of violator was of chaotic character. Participant had to pass situation into peaceful manner. We evaluated: sureness of behavior; tone of speech; tactic techniques; creative approach to the solution of problem (initiative); manner of movements; application of improvised means, position. All ready made combinations of actions started suddenly for participants and order of positions' demonstration was rather variable. With it participant of experiment (or other persons) had to timely respond to the moment of appearing of potential or direct threat. Further progressing of situation was stopped by one of experts.

At the same time trainees put brief characteristics to own actions from the point of adequacy in respect to manifested threat. Criteria of task's fulfillment were: time for perception of situation and threat; time for taking decision; time for taking certain position; correctness of respond to threats; own actions and actions, which could result in certain legal after effects.

Evaluation of correctness of perception and adequacy of analysis was carried out by commission of three experts: two specialists in physical training and tactics and specialists lawyer. Evaluation system includes: 1. Adequacy of actions for taking decision and level of threat; 2. Time of execution; 3. Evaluation of actions in respect to degree of threat; 4. Positional location;, preventing from aggressive adversary's actions, readiness for actions, own safety.; 5. Legal characteristic of every certain moment: what threat can appear in respect to legal field. 
Level of adequacy of law officers' respond to threats

\begin{tabular}{|c|c|c|c|c|c|c|c|c|c|c|c|c|}
\hline \multirow[b]{2}{*}{ Tasks } & \multicolumn{2}{|c|}{$\begin{array}{c}\text { Adequacy } \\
\text { (correctness) } \\
\text { of motion } \\
\text { behavior }\end{array}$} & \multicolumn{2}{|c|}{ Confidence } & \multicolumn{2}{|c|}{$\begin{array}{c}\text { Emotions } \\
\text { manners of } \\
\text { behavior and so } \\
\text { on. }\end{array}$} & \multicolumn{2}{|c|}{ Confidence } & \multicolumn{2}{|c|}{$\begin{array}{l}\text { Legal after } \\
\text { effects }\end{array}$} & \multicolumn{2}{|c|}{ Confidence } \\
\hline & $\begin{array}{c}\text { CG } \\
(\mathbf{n}=\mathbf{3 0} \\
\mathbf{X}^{ \pm} \\
\mathbf{m}\end{array}$ & $\begin{array}{c}\mathbf{E G} \\
(\mathbf{n}=\mathbf{3 0} \\
), \mathbf{X} \pm \\
\mathbf{m}\end{array}$ & $\mathbf{t}$ & $\mathbf{P}$ & $\begin{array}{c}\mathbf{C G} \\
(\mathbf{n}=\mathbf{3 0} \\
) \\
\mathbf{X} \pm \mathbf{m}\end{array}$ & $\begin{array}{c}\mathbf{E G} \\
(\mathbf{n}=\mathbf{3 0}) \\
\mathbf{X} \pm \mathbf{m}\end{array}$ & $\mathbf{t}$ & $\mathbf{P}$ & $\begin{array}{c}\mathbf{C G} \\
(\mathbf{n}=\mathbf{3 0} \\
\quad) \\
\mathbf{X} \pm \mathbf{m}\end{array}$ & $\begin{array}{c}\mathbf{E G} \\
(\mathbf{n}=\mathbf{3 0} \\
\quad) \\
\mathbf{X} \pm \mathbf{m}\end{array}$ & $\mathbf{t}$ & $\mathbf{P}$ \\
\hline $\begin{array}{l}\text { Testing } \\
\text { (90question } \\
\text { s) }\end{array}$ & $\begin{array}{c}13.5 \pm \\
0.64\end{array}$ & $\begin{array}{c}64.8 \pm \\
0.98\end{array}$ & $\begin{array}{c}43.82 \\
9\end{array}$ & $\begin{array}{c}<0.00 \\
1\end{array}$ & $\begin{array}{l}6.3 \pm \\
0.28\end{array}$ & $\begin{array}{c}53.1 \pm 1 \\
3\end{array}$ & $\begin{array}{c}35.1 \\
9\end{array}$ & $\begin{array}{c}<0.00 \\
1\end{array}$ & $\begin{array}{c}35.1 \pm \\
0.92\end{array}$ & $\begin{array}{c}54.9 \pm \\
1.1\end{array}$ & 3.81 & $\begin{array}{c}<0.00 \\
1\end{array}$ \\
\hline $\begin{array}{l}\text { Actions in } \\
\text { simulation } \\
\text { of extreme } \\
\text { situation } \\
\text { (30 } \\
\text { episodes) }\end{array}$ & $\begin{array}{l}6.9 \pm \\
0.35\end{array}$ & $\begin{array}{c}20.1 \pm \\
0.68\end{array}$ & $\begin{array}{c}17.26 \\
0\end{array}$ & $\begin{array}{c}<0.00 \\
1\end{array}$ & $\begin{array}{l}3.6 \pm \\
0.26\end{array}$ & $\begin{array}{c}19.2 \pm 0 \\
57\end{array}$ & $\begin{array}{c}24.9 \\
0\end{array}$ & $\begin{array}{c}<0.00 \\
1\end{array}$ & $\begin{array}{c}12.9 \pm \\
0.39\end{array}$ & $\begin{array}{l}19.5 \pm \\
0.71\end{array}$ & $\begin{array}{c}8.14 \\
8\end{array}$ & $\begin{array}{c}<0.00 \\
1\end{array}$ \\
\hline
\end{tabular}

Effectiveness of tasks' solution by EG members in respect to CG is given in table 1.

It should be noted that $10 \%$ of participants from EG were not in time with fulfillment of tasks, while in CG $40 \%$.

\section{Discussion}

The worked out by us methodic is a new project in professional training. Scientific novelty is that for the first time we used new algorithm of law officers' training, for formation of knowledge and skills in practical functioning in extreme situations. We proved experimentally effectiveness of actions in time, recognition and perception of threat, choosing of actions and responding to danger.

In experimental group perception time of threat from the moment of its appearing was in average 1.5-2 sec. Time for taking decision - 1-1.5 sec. Time of taking position coincides with time of taking decision and is approximately 1-2 sec. In CG time range was wider - from У КГ 1 to $7 \mathrm{sec}$. It witnesses about different perception of threatening actions. Some trainees showed certain delay in perceiving of actions' combinations and evaluation. Tim for determination of situation was delayed or excessively accelerated. Such response was registered because of seeking of threat's degree or as too early in respect to event itself (taking position). In experiment it was noted that with every following participation in demonstration of motion and behavioral combinations most of trainees improved their indicators by all items. So, method of fulfillment of experiment, selection of means were approximated to academic process. If during fulfillment of first two-three tasks in EG indicators of effectiveness were 60-65\%, in second - (CG) 20 - 23\%, then by the end of all tasks indicators significantly improved. Adaptation of participants to experiment's conditions also played important role. At the beginning of test we observed certain psychological tension and there was a trend to reduction of indicators.

Results of the research are in accordance with experts' opinion (V.V. Bondarenko, Yu.V. Denisenko, L.N. Kucheriaviy).

Conclusions:

Our researches showed that effectiveness of cadets' training to special physical and tactic fitness increases significantly with purposeful formation of knowledge and skills in recognitions of different by level threats. At first stage of training cadets (law officers) had to master knowledge about gradations of different situations (typical and not standard), moments of threats' appearing, their consequences, in determination of differentiating factors. Then the mastered knowledge is trained to level of skills. I.e. for short time (in seconds) threat and its after effects are determined. After it, it is necessary to master variants of responding to different threats' manifestations. At second stage of training some cadets simulate different levels of threat and other - respond to them. At third stage sudden threat is simulated, to which it is necessary to adequately respond. Fulfillment is restricted by time.

It was determined that in process of simulated situations of conflict with aggressive adversary cadets substantially increased adequacy of responding to appeared threat during fulfillment (within legal frames). Recognition of aggressiveness level was determined by manifested manners of adversary, his emotions, motivations, motion 
behavior during 2-3 seconds. Development of attention, ability to orient, to perceive, to be ahead in actions is also important.

\section{References:}

1. Belkin R.S. Teoriia i praktika sledstvennogo eksperimenta [Theory and practice of investigative experiment], Moscow, Graduate School of the USSR Ministry of Internal Affairs, 1959, 169 p. (In Russian)

2. Plisko V. I., Nosko M. O. Vikoristannia zakhodiv fizichnogo vplivu z taktichnim osmislenniam situacii vidpovidno do stupenia zagrozi [The use of physical impact of tactical understanding of the situation according to the degree of threat], Chernihiv, 2010, 284 p. (In Ukrainian)

3. Plisko V.I. Formirovanie gotovnosti professionala $k$ deiatel'nosti $v$ usloviiakh, opasnykh dlia zhizni: na materialakh sub"ekt-sub"ektnoj deiatel'nosti [Formation of readiness to professional activity in conditions hazardous to life on the materials the subject of subjective activity], Kiev, Scientific World, 2002, 304 p. (In Russian)

4. Davydov V.V. Psikhologicheskij slovar' [Psychological dictionary], Moscow, 1983, pp. 370. (In Russian)

5. Khramovich M.A. Nauchnyj eksperiment, ego mesto i rol'v poznanii [Scientific experiment, its place and role in cognition], Minsk, BU V.I. Lenin Publ., 1972, 230 p. (In Russian)

6. Banakh S.M., Bulachek V.R., Viniarchuk I.S., Josipiv Iu.R. Taktiko-special'na pidgotovka pracivnikiv OVS Ukraini [Tactical and special training of policemen of Ukraine], Lviv, LvDUVS, 2011, 300 p. (In Ukrainian)

7. Shojgu Iu.S. Psikhologiia ekstremal'nykh situacij dlia spasatelej i pozharnykh [Psychology of extreme situations for the rescuers and firefighters], Moscow, Meaning, 2007, 319 p. (In Russian)

8. Anufriiev M. I, Butov S. Ye, Gida O. F., Reshko S. M. Osnovi special'noi fizichnoi pidgotovki pracivnikiv OVS [Fundamentals of special physical training police officers], Kiev, 2003, 338 p. (In Ukrainian)

9. Babenko V. G., Popov O. V., Ianko I. V. Zakhodi fizichnogo vplivu [Measures of physical restraint], Kiev, 2001, 24 p. (In Ukrainian)

10. Zakorko I. P. Special'na fizichna pidgotovka u vishchikh navchal'nikh zakladakh MVS Ukraini z urakhuvanniam individual'nikh osoblivostej motoriki kursantiv. Kand.diss. [Physical training in higher educational establishments of Ukraine, taking into account the individual characteristics of motor cadets. Cand. Diss.], Kiev, 2001, 300 p. (In Ukrainian)

11. Smirnov B.A., Dolgopolova E.V. Psikhologiia deiatel'nosti v ekstremal'nykh situaciiakh [Psychology of activity in extreme situations], Kharkov, Humanitarian Center Publ., 2007, 276 p. (In Russian)

12. Yevsiukov O.P. Ekstremal'na psikhologiia [Extreme psychology], Kiev, Ltd. "August Trade", 2007,502 p. (In Ukrainian)

13. Bondarenko V. V. Model' iakostej pracivnika milicii, iaka nadaie jomu perevagu $\mathrm{v}$ umovakh nespodivanogo zitknennia z ozbroienim suprotivnikom [Model properties of militia worker, which gives him an advantage in terms of unexpected collision with an armed enemy]. Visnik Chernigivs'kogo derzhavnogo pedagogichnogo universitetu, 2010, no.81, pp. 136 - 140. (In Ukrainian)

14. Lefterov V.O. Osobistisno-profesijnij rozvitok fakhivciv ekstremal'nikh vidiv diial'nosti. Dokt.diss. [Personally professional development of specialists of extreme activities. Dokt.diss.], Kharkov, 2008, 37 p. (In Ukrainian)

15. Artamanova G.K., Mameeva I.S. Organizacionnye i pravovye formy i metody deiatel'nosti po sozdaniiu normativno-pravovoj bazy v sfere obespecheniia pozharnoj bezopasnosti [Organizational and legal forms and methods of work to create the legal framework in the field of fire safety]. Vestnik Sankt-Peterburgskogo universiteta GPS MChS Rossii. 2012, no.2, pp. 97-102. (In Russian)

16. Kartashov V.N. Iuridicheskaia tekhnika, taktika, strategiia i tekhnologiia [Legal technique, tactics, strategy and technology (to the question of the relationship)]. Problemy iuridicheskoj tekhniki, 2005, no.1, pp. 111. (In Russian)

17. Kazakov Iu.N. Psikhologo-akmeologicheskaia sushchnost' ekstremal'nykh situacij v deiatel'nosti municipal'nykh sluzhashchikh [Psychological akmeological essence of extreme situations in the work of municipal employees], Municipal'naia sluzhba: pravovye voprosy, 2008, no.4, pp. 20-26. (In Russian)

18. Derkach A.A., Zazykin V.G. Professionalizm deiatel'nosti v osobykh i ekstremal'nykh usloviiakh [Professionalism activity in special and extreme conditions], Moscow, RAGS, 1998, 178 p. (In Russian)

19. Dmitrenko I.A. Ekologichne pravo Ukraini [Environmental Law of Ukraine], Kiev, Inter Yurinkom, 2001,352 p. (In Ukrainian)

20. Strekozov V.G. Voennoe pravo [Military law], Moscow, 2004, 640 p. (In Russian)

21. Belur J., Tilley N., Osrin D., Daruwalla N., Kumar M., Tiwari V. Police investigations: discretion denied yet undeniably exercised. Policing and Society. 2014, vol.1, no.24, pp. 45-55. http://dx.doi.org/10.1080/10439463.2013.878343.

22. Dean G., Fahsing I.A., Glomseth R., Gottschalk P. Capturing knowledge of police investigations: towards a research agenda. Police Practice and Research. 2008, vol.9, no.4, pp. 341-355. http://dx.doi.org/10.1080/15614260802354650.

23. Dean G., Fahsing I.A., Gottschalk P. Profiling police investigative thinking: A study of police officers in Norway. International Journal of the Sociology of Law. 2006, vol.34, no.4, pp. 221-228. http://dx.doi.org/10.1016/j.ijsl.2006.09.002. 
24. Glomseth R., Gottschalk P., Solli-Sæther H. Occupational culture as determinant of knowledge sharing and performance in police investigations. International Journal of the Sociology of Law. 2007, vol.35, no.2, pp. 96107. http://dx.doi.org/10.1016/j.ijsl.2007.03.003.

25. Heinonen A., Ellonen N. "Crime or not?" - police officers' perceptions of disciplinary violence, its criminalisation and its investigation. Policing and Society. 2014, vol.1, no.19, pp. 56-62. http://dx.doi.org/10.1080/10439463.2014.989151.

26. Royds D. Death Investigation. A Handbook for Police Officers. Australian Journal of Forensic Sciences. 2002, vol.34, no.2, pp. 93-94. http://dx.doi.org/10.1080/00450610209410843.

27. Ryan B.J. What the Police are Supposed to Do: Contrasting Expectations of Community Policing in Serbia. Policing and Society. 2007, vol.17, no.1, pp. 1-20. http://dx.doi.org/10.1080/10439460601124106.

28. Semukhina O. Public assistance of police during criminal investigations: Russian experience. Police Practice and Research. 2014, vol.1, no.20. pp. 67-73. http://dx.doi.org/10.1080/15614263.2014.949263.

29. Thomassen G. Investigating Complaints against the Police in Norway: An Empirical Evaluation. Policing and Society. 2002, vol.12, no.3, pp. 201-210. http://dx.doi.org/10.1080/10439460290018445.

30. Walker S. The neglect of police unions: exploring one of the most important areas of American policing. Police Practice and Research. 2008, vol.9, no.2, pp. 95-112. http://dx.doi.org/10.1080/15614260802081253. 
Information about the authors:

Radzievskiy R. M.: http://orcid.org/0000-0002-9600-7383;

vikastar2002@ukr.net; Chernigov National Pedagogical University;

Getman Polubotka str. 53, Chernigov, 14013, Ukraine.

Plisko V.I.: http://orcid.org/0000-0001-7222-2057; vikastar2002a@ukr. net; Chernigov National Pedagogical University; Getman Polubotka str. 53, Chernigov, 14013, Ukraine.

Cite this article as: Radzievskiy R.M., Plisko V.I. Law enforcers recognition level emerging threats based on physical appearance and behavior signs the enemy. Physical education of students, 2015, no.1, pp. 50-59. http://dx.doi.org/10.15561/20755279.2015.0108

The electronic version of this article is the complete one and can be found online at: http://www.sportpedu.org.ua/html/arhive-e.html

This is an Open Access article distributed under the terms of the Creative Commons Attribution License, which permits unrestricted use, distribution, and reproduction in any medium, provided the original work is properly cited (http:// creativecommons.org/licenses/by/3.0/deed.en).

Received: 15.11 .2014

Accepted: 27.12.2014; Published: 30.12.2014 


\title{
PROFESSIONAL PORTRAIT OF FUTURE INSTRUCTORS FOR PHYSICAL EDUCATION OF PRESCHOOL
}

Semanychyn T.M., Popel' S.L.

Prikarpatskiy National University

\begin{abstract}
Annotation. Purpose: identify the degree of readiness of students to conduct valeological activity in preschool educational institutions. The objective of the study was to identify the relationship between educational level and health education and readiness of students to valeological activities. Material: in the experiment took part 550 students. $\underline{\text { Results: }}$ : the survey allowed to establish pedagogical assumptions that characterize the training of students. This will include valeological activity for the formation of their own culture valeological children. It is shown that students' valeological culture is a prerequisite for the effective functioning of the system in pre-secondary institutions. It is noted that the training of students of the Faculty of Physical Education and Sports to valeological activity is low. Conclusions: studies have shown that only $11.7 \%$ of the students have been trained and have the necessary knowledge and practical skills.
\end{abstract}

Keywords: physical education, valeology, culture, children, instructor.

\section{Introduction}

After I.I. Brekhman's [9] introducing of term "valueology as science about health" many specialists try to carry out valueology activity among wide strata of population $[5,10,12]$. With it they pay special attention to children. Recent time valueology knowledge has become integral part of training of highly qualified specialists in system of physical education [8]. Cultivation of students' valueology culture is a core and, at the same time, a determining condition of effective functioning of such system in children educational establishments (CEE).

Valueology orientation of modern education in Ukraine, oriented on a person as the highest value of social being regards him (her) as a subject of cognition, communication and creativity. That is why it is so important to create conditions, in which person would take position of "creator" of own personality in constantly varying modern social environment [11].

The problems connected with formation of valueology culture were elucidated in works of many scientists [1, $3,6]$. Considering their results we can say that training of students at physical culture and sports faculty to valueology functioning corresponds to realization of their own creative potential.

Nowadays term "valueology culture" is interpreted in different ways. It is often is understood as: regulated [7];

- system of knowledge and ideas, on the base of which health related human functioning is constructed and

- high level of ecological thinking, its orientation on HLS, ability to quickly change manner of actions in compliance with new conditions of environment[8];

- special quality, which characterizes measure of certain social role for correspondence of individual's qualities to social standards, which id required for self determination of valueology activity's subject [1];

- one of aspects and, at the same time, axiological potential of personality, who takes position of "creator" of own somatic health in condition of modern social environment $[3,7]$;

- humanistic orientation of modern valueology education in Ukraine with its orientation on a person as the highest value of social being and regards him (her) as a subject of cognition, communication and creativity [11];

- social-psychological setting for non-traditional solution of contradictions of objective reality, connected with practicing of HLS [13];

- integrating and synthetic quality, characterizing the measure of personality's potentials for creative valueology functioning $[2,4]$;

- integral personality's quality, expressed in relation (position, orientation) of a person to own health [15-17];

- combination of real potentials, skills for practicing of HLS, which determine level of valueology education $[5,18-21]$.

From medical point of view valueology culture or culture of health is a part of general culture and is a reasonable system of actions and relations to own health and health of other people, i.e. ability to live not injuring own organism but benefiting it [14]. With it scientists mention that health culture implies not simple "collecting" of useful recommendations but active application of them in everyday practice.

Valueology culture implies also ability to propagate valueology knowledge. Pedagogues shall cultivate firm motivation for health and healthy life style (HLS) starting from pre school age (with the help of academic programs, pedagogic work with parents, with own example in everyday communication).

Thus, it is evident that it is necessary to have interconnection between educational and health related directions in pre school educational establishments. Such interconnection can be ensured by readiness of modern student and future instructor of physical culture in CEE for valueology functioning on the base of system of valueology knowledge, which forms certain level of valueology culture.

\footnotetext{
(C) Semanychyn T.M., Popel' S.L., 2015

http://dx.doi.org/10.15561/20755279.2015.0109
} 


\section{Purpose, tasks of the work, material and methods}

The purpose of the work is to determine the level of readiness of physical culture and sports faculty for valueology functioning.

The main tasks of the research were analysis of scientific literature on theoretical principles of physical culture instructors' training and carry out questioning of students, devoted their readiness for valueology functioning.

The methods and organization of the research. Modern status of training of future physical culture instructors of pre school children for valueology functioning was studied by us with the help of empiric methods, i.e. questioning of 550 HEE students of Ukraine.

The questionnaire had several parts, concerning presence and development of own resources, facilitating formation of valueology culture, strategy and skills in prevention from HLS violation, knowledge of professional valueology culture's structure, its cognitive development, acquiring of personal professional knowledge and creation of functional behavior's strategy. Such construction of questionnaire permits to more completely evaluate problems and disadvantages in theoretical and methodic valueology preparation of future physical culture instructors of pre school educational establishments.

Evaluation was fulfilled by 5-points' scale. All results were processed by methods of parametrical statistics with the help of "Statistika 5" programs.

Results of the research. Discussion.

Characteristics of valueology knowledge are given in table 1. Results of analysis showed that most of the questioned students $(86.7 \%)$ have no oriented understanding of own resources, which would facilitate formation of pre school children's HLS.

Table 1

Characteristics of knowledge and skills of $3^{\text {rd }}-05^{\text {th }}$ year students of physical education and sports faculty in sphere of valueology culture $(n=550, \%)$

\begin{tabular}{|c|c|c|c|c|c|}
\hline Characteristics of knowledge and skills in sphere of valueology culture & +2 & +1 & $\overline{0}$ & 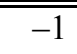 & 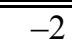 \\
\hline Available personal resources, facilitating formation of valueology culture & 2.1 & 6.8 & 72.3 & 10.9 & 7.9 \\
\hline $\begin{array}{l}\text { Development of personal resources facilitating formation of valueology } \\
\text { culture }\end{array}$ & 6.9 & 12.1 & 69.3 & 5.7 & 6.0 \\
\hline Development of strategy and behavior for prevention of HLS violations & 2.0 & 16.5 & 36.8 & 19.3 & 25,4 \\
\hline \multicolumn{6}{|l|}{ Structure of professional valueology culture. } \\
\hline 1. Cognitive development & 3.0 & 8.1 & 60.5 & 12.0 & 16.9 \\
\hline 2. Development of personal professional resources & 4.6 & 10,3 & 20.1 & 40.4 & 2.6 \\
\hline 3. Development of strategy of functional behavior and skills & 10.2 & 12.5 & 30.3 & 30.6 & $1 . .4$ \\
\hline
\end{tabular}

Question "Do you have own ready system of values, targets and settings in sphere of HLS?" positive answer was given only by $14.2 \%$ of the questioned; "cannot answer" - by $53.4 \%$ : "don't have" - by $32.4 \%$. With it, it was determined that $66.9 \%$ students are not able to communicate with children professionally; $43.2 \%$ do not know how to solve their life problems; $77.9 \%$ - cannot evaluate situations in children collective and cannot use own professional potentials to control such situations. In our opinion this can be explained by quantity of negative points (92.3\%), received by students for their answer to question: "Do you understand behavior of children, render them psychological and social support?"

Low level of valueology fitness of future specialists in pre school physical education is also proved by data about development of personal resources, facilitating formation of valueology culture. More than half $(56.1 \%)$ of respondents have no personal resources, facilitating determination of own mistakes in HLS practicing; $45.6 \%$ points at inability to adequately evaluate problem situations and solve life problems; $68.8 \%$ cannot change themselves and their life; nearly one third (32.3\%) cannot control own behavior and $55.2 \%$ are not able to listen to children.

The latter is explained by the fact that more than $2 / 3$ of students are not able to express own feelings and take decisions on psychological-social children's support.

Such status of students' valueology training reflects in certain way on their ability to work out strategy and behavioral skills for prevention of HLS violations. It was determined that $72.3 \%$ cannot take decisions on overcoming of harmful habits, while $45.3 \%$ do not take such habits as harmful at all. With it only $30.2 \%$ of students can evaluate social situation and feel responsibility for own behavior; $34.7 \%$ can defend own rights and personal space. Insignificant part of students $(24.2 \%)$ can defend own "Self", are able for self-support and support. Most students (76.3\%) cannot 
avoid situations, connected with taking harmful substances and other forms of destructive behavior. However $98.6 \%$ of respondent mentioned about ability for non conflict effective communication, including with pedagogues.

Thus, we received answers to three blocks of questions, which touched on characteristics of knowledge and skills in sphere of valueology culture and these answers point at insufficient students' knowledge, at demand in acquiring of such knowledge for successful future professional functioning.

Correction of situation, which exists in this problem, can imply correction of evaluation points with answering on cognitive structure of students' professional valueology education. It was found that holistic idea about processes and phenomena, which occur in nature, only $46.8 \%$ of students have. From them $91.2 \%$ understand potentials of modern scientific methods of cognition of nature. However, only $12.4 \%$ know these methods and are able to apply them in professional functioning. Only $30.1 \%$ have some knowledge about main mental functions of a child, but $78.9 \%$ have knowledge about main human mental functions. So, knowledge of children's psychology requires more attention from the side of pedagogues to students, who are taught to practice valueology activity in pre school educational establishments. Data, concerning development of personal professional resources, were also interesting: $41.1 \%$ of students have skills in analysis of educational situations. Only $23.4 \%$ of them know general philosophical laws of culture of thinking; $26.9 \%$ can express results of educational, scientific and pedagogic functioning both in oral and written forms. Only 37.2 of respondents know national specificities of everyday life, family and family education and can use their knowledge in work. Only one third (33.1\%) of students think that they have high level of personal health and only $11.7 \%$ can feel responsibility for health and life of other people. All these, undoubtedly influence on development of strategy of students' functional behavior and skills in mastering of own valueology culture. Positive answer to question: "Do you know and apply modern methods of scientific cognition?" was given only by $25.3 \%$ from them, while only $10.4 \%$ of respondents know the principles of organizational-sociological researches. Nearly half $(48.7 \%)$ of positive answers were received to question: "Do you have means and methods of pedagogic influence on personality?", with it only $24.6 \%$ from them have knowledge of general and individual features of child's mentality; $22.1 \%$ - use in pedagogic process knowledge of main biological processes, mechanisms, phenomena and etc.

It should be noted that only $25.3 \%$ of respondents consider themselves to be ready for re-evaluation of experience, accumulated by science and social practice in sphere of children's physical education in pre school educational establishments. The most troublesome are students' answers to such challenges of modern system of preschool education as usage of modern informational educational technologies (only $12.3 \%$ of positive answers), knowledge of modern psychological methodic of correction of child's psycho-emotional state (8.9\%), ability to diagnose temper and character of a child (3.4\%), ability to compose psychological characteristic of a child (6.6\%), to personally determine the nearest prospects of a child (5.9\%), determination of psychological climate of children's group $(9.2 \%)$ and sociological; status of a child in group $(7.1 \%)$. Not less troublesome is inability in $63.2 \%$ of cases to determine type of family relations and type of family education. Only $18.6 \%$ of students can carry out work on prevention from family conflicts. With it, it is no surprising that very little part $(3.1 \%)$ of students can compose programs for correction of children's behavior in family. However, rather significant percentage (47.2\%) of students can practically apply knowledge and skills in pedagogic influence on older sociological strata of people. Such status of valueology problem requires integrated program of continuous valueology education for receiving by students both general and basic valueology competences.

Formation of modern strategy of students' functional behavior and skills for formation of own valueology culture is called for also by very low percentage of positive answers to question about ability to create safe and friendly atmosphere in children's collective $(9.5 \%)$, to bring knowledge "between lines", i.e. use non-verbal component of communication (14.2\%), have knowledge of children's styles and methods of material's mastering and great stock of different forms of teaching functioning (4.7\%), are satisfied with work with children and enjoy with it (16.5\%).

Analysis of answers to questions, touching on employment and competence in valueology functioning in $\mathrm{CEE}$ is shown in fig. 1 and 2 .

It was found that staff positions in CEE are engaged by workers from other branches, who passed brief course of retraining as instructors in pre school children physical culture. Answers to first question "Do you agree that owing to deficit of specialists in valueology the appropriate positions are engaged by workers from other branches - coaches, physical culture school teachers, after brief retraining course?" distributed in the following way: from 550 of respondents $48.2 \%$ agreed with our opinion, 32.8\% - agreed partially, 11,7\% - did not agree, for $7.3 \%$ it was difficult to answer.

The second question: "To what extent do you have knowledge about valueology functioning in CEE?" results distributed in the following way: from 550 of respondents only $11.1 \%$ of students have knowledge in this field, $39.2 \%-$ have partial knowledge, $36.8 \%$ - have no knowledge and for $12.9 \%$ of students it was difficult to answer. 


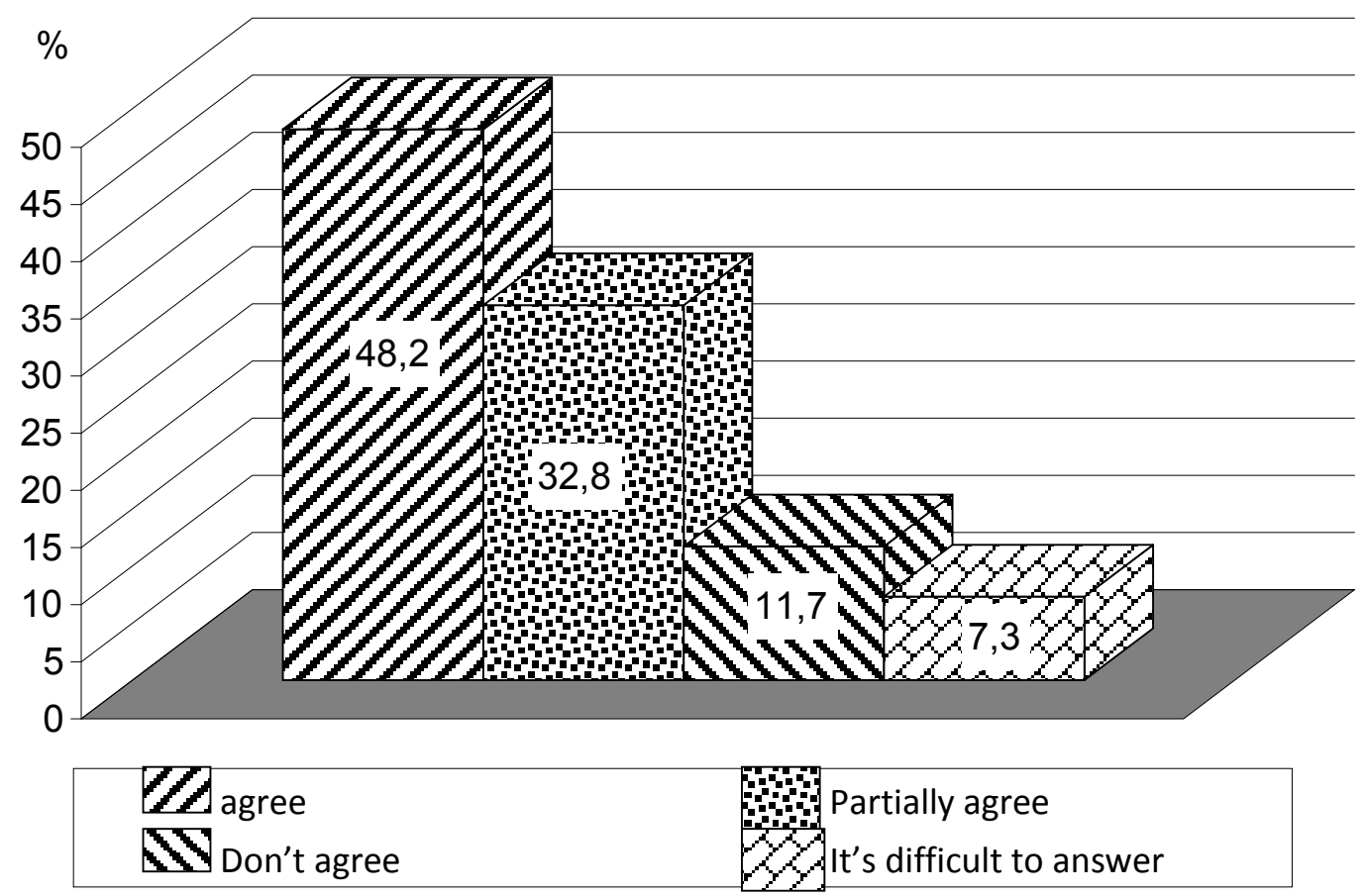

Fig.1. Quantity of students, questioned about staff provisioning for valueology functioning in CEE.

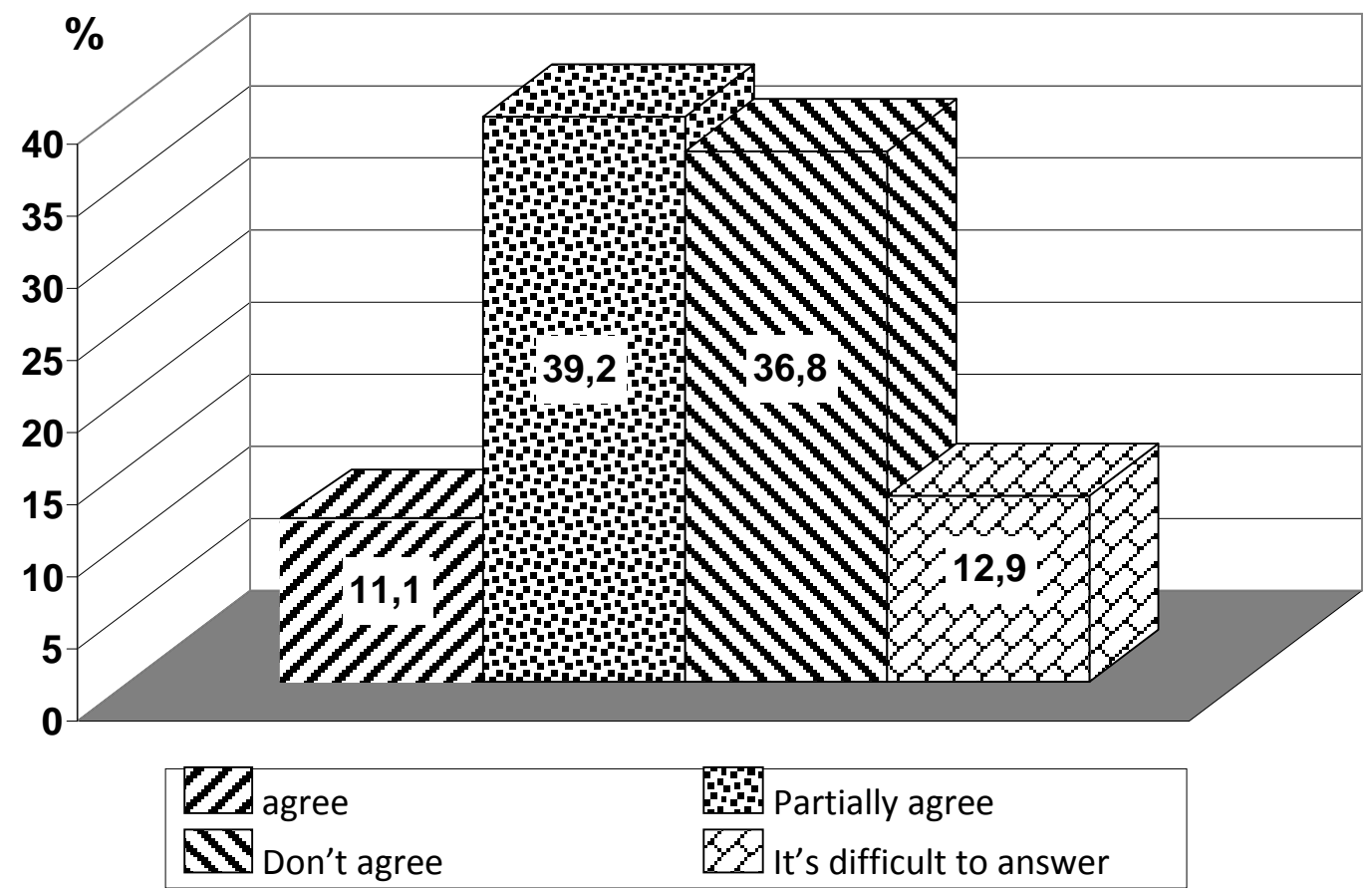

Fig.2. Quantity of students, questioned about knowledge of valueology functioning technologies in CEE (\%).

Therefore, very little quantity of students, videlicet $11.1 \%$, have sufficient level of valuelogy culture and knowledge about valueology functioning in CEE that witness about urgency and purposefulness of this problem. 


\section{Conclusions:}

1. On the base of analysis of pedagogic literature and research of theoretical principles of professional training of future physical education instructors for valueology functioning in CEE we showed that only $11.7 \%$ of the questioned students have proper fitness and required knowledge and skills.

2. Formation of future physical education instructor's readiness for valueology functioning is oriented on opening of higher educational establishment student's potentials to successfully respond to new requirements of social environment.

3. Future physical education instructor in CEE shall be professionally competent creative, humanistic personality with prevailing spiritual-moral qualities and brightly expressed subjective position, individual style of functioning and significant creative potential.

The prospects of further researches in this direction are working out of scientific-methodic complexes for effective training of CEE future physical education instructor for practicing of valueology activity.

\section{References:}

1. Aliev M.N., Gusejnov A.G. Vospitanie nravstvenno-volevykh kachestv u detej sredstvami fizicheskoj kul'tury [Education of moral and volitional qualities in children by means of physical culture]. Pedagogika, 2008, no.1, pp. 67-73. (In Russian)

2. Kovtun R.F. Podgotovka molodykh specialistov vysshikh uchebnykh zavedenij $k$ vospitatel'noj rabote so studentami. Kand.diss. [Training of graduates of higher educational institutions for educational work with students. Cand. Diss.], Chelyabinsk, 2005, 327 p. (In Russian)

3. Korotaeva E.V. Kachestvo podgotovki budushchego pedagoga [The quality of training of future teachers]. Pedagogika [Pedagogy], 2006, no.9, pp. 61-66. (In Russian)

4. Krucevich T.Iu. Teoriia $i$ metodika fizicheskogo vospitaniia [Theory and methodology of physical education], Kiev, 2003, 423 p. (In Russian)

5. Kutek T. [Features of the learning process of future industry professionals "Physical Culture and Sports"]. Molodaia sportivnaia nauka Ukrainy [Young sports science in Ukraine], 2009, no.4, pp. 90 - 94. (In Russian)

6. Kuc A., Tret'iakov M., Lapichak I. Integraciia cennostej fizicheskoj kul'tury v professional'noj podgotovke pedagoga po fizicheskomu vospitaniiu [Integration of the values of physical culture in teacher training in physical education]. Pedagogika, psihologia ta mediko-biologicni problemi fizicnogo vihovanna $i$ sportu, 2003, no.1 pp. 119-124. (In Russian)

7. Martishina N.V. Cennostnyj komponent tvorcheskogo potenciala lichnosti pedagoga [Value component of creative potential of the teacher]. Pedagogika, 2006, no.3, pp. 48-57. (In Russian)

8. Matveev L.P. Teoriia i metodika fizicheskoj kul'tury [Theory and methods of physical culture]. Sankt Petersburg, Lan, Omega, 2004, 159 p. (In Russian)

9. Moskalenko N.V. Innovacionnaia programma razvitiia fizkul'turno-ozdorovitel'noj raboty $\mathrm{v}$ obshcheobrazovatel'nykh shkolakh [Innovative program of development sports and recreation activities in secondary schools]. Sportivnij visnik Pridniprov'ia, 2005 no.2, pp. 37-40. (In Russian)

10. Nikolaev Iu.M. Obshchaia teoriia i metodologiia fizicheskoj kul'tury [General theory and methodology of physical education]. Teoriia i praktika fizicheskoj kul'tury, 2005, no.11, pp. 9-14. (In Russian)

11. About the state and prospects of development of adult education: college decision MES from 27.11.2008, vol. 14 / 3-3. Information Collection MES of Ukraine, 2009, no.1, pp. 31-45. (In Russian)

12. Skarednova I.V. [Development and implementation of modular routines aimed at creating culture of healthy and safe lifestyle of younger students]. Opyt vnedreniia federal'nykh gosudarstvennykh obrazovatel'nykh standartov nachal'nogo obshchego obrazovaniia v Tiumenskoj oblasti [Experience of implementing the federal state educational standards of primary education in the Tyumen region], Tyumen, 2012, pp. 33-36. (In Russian)

13. Solov'ev G.M. Genezis stanovleniia sovremennogo celepolaganiia po fizicheskoj kul'ture v sisteme obrazovaniia [The genesis of the emergence of modern goal setting in physical culture in the education system]. Teoriia i praktika fizicheskoj kul'tury, 2003, no.8, pp. 10-14. (In Russian)

14. Usol'ceva L.A. [Creating the conditions for a healthy lifestyle in a GEF implementing children]. Opyt vnedreniia federal'nykh gosudarstvennykh obrazovatel'nykh standartov nachal'nogo obshchego obrazovaniia $v$ Tiumenskoj oblasti [Experience of implementing the federal state educational standards of primary education in the Tyumen region], Tyumen, 2012, pp. 32-33. (In Russian)

15. Iakovleva I.V. [Actual issues of culture of a healthy and safe lifestyle during the implementation of the GEF]. Opyt vnedreniia federal'nykh gosudarstvennykh obrazovatel'nykh standartov nachal'nogo obshchego obrazovaniia v Tiumenskoj oblasti [Experience of implementing the federal state educational standards of primary education in the Tyumen region], Tyumen, 2012 pp. 30-32. (In Russian)

16. Jang S-J., Tsai M-F., Chen H-Y. Development of PCK for novice and experienced university physics instructors: a case study. Teaching in Higher Education. 2013, vol.18, no.1, pp. 27-39. http://dx.doi.org/10.1080/13562517.2012.678329. 
17. Osova O.O. contribution of native teachers of the second half of the XIX-th century to the working out of the teacher's problem. Pedagogics, Psychology, Medical-Biological Problems of Physical Training and Sports. 2009, no.1, pp. 103 - 105.

18. Sá M.M., Azevedo R., Martins C., Machado O. Portuguese Physical Education Instructors’ Exposure to Noise and Perception of Associated Risk. Human and Ecological Risk Assessment: An International Journal. 2014, vol.20, no.2, pp. 448-460. http://dx.doi.org/10.1080/10807039.2013.786922.

19. Semanyshyn T.M., Popel S.L. The professional valeological portrait of instructor of physical culture. Pedagogics, psychology, medical-biological problems of physical training and sports, 2014, no.10, pp. 41-44. http://dx.doi.org/10.5281/zenodo.10489

20. Whitehead K., Thorpe S. The problematic place of a woman physical education instructor: an historical case study. Gender and Education. 2004, vol.16, no.1, pp. 77-95. http://dx.doi.org/10.1080/0954025032000170354. 
Information about the authors:

Semanyshyn T.M.: http://orcid.org/0000-0001-5043-3208; stmifua@ gmail.com; Prikarpatskiy National University; T.Shevchenko str., 44-a, Ivano-Frankovsk, 76018, Ukraine.

Popel S.L.: http://orcid.org/0000-0001-9019-3966; serg_popel@mail. ru; Prikarpatskiy National University; T.Shevchenko str., 44-a, IvanoFrankovsk, 76018, Ukraine.

Cite this article as: Semanychyn T.M., Popel' S.L. Professional portrait of future instructors for physical education of preschool Physical education of students, 2015, no.1, pp. 60-66. http://dx.doi org/10.15561/20755279.2015.0109

The electronic version of this article is the complete one and can be found online at: http://www.sportpedu.org.ua/html/arhive-e.html

This is an Open Access article distributed under the terms of the Creative Commons Attribution License, which permits unrestricted use, distribution, and reproduction in any medium, provided the original work is properly cited (http:// creativecommons.org/licenses/by/3.0/deed.en).

Received: 10.11.2014

Accepted: 10.12.2014; Published: 30.12.2014 


\section{INFLUENCE EMPLOYMENT BY IMPROVING AEROBICS ON MOTOR READINESS OF GIRLS}

Shypulo I. P.

Chernihiv National Pedagogical University

Annotation. Purpose: substantiate the effect of employment by improving aerobics on motor readiness of girls in extracurricular educational institutions. Material: the study involved 90 women aged 16-18 years old. Classes are held 3 times a week for 1 hour each. Results: defined state and the most informative indicators motor fitness girls. Built analytical model of graph model for forecasting and conducting quantitative and qualitative control of motor fitness girls. The degree of severity of each of the parameters studied motor fitness girls. Conclusions: the possibilities of predicting outcomes. Recommended method of aerobics classes, which has five stages. Its main feature - the constant objective control efficiency of employment.

Keywords: classes, aerobics, motion, training, girls.

\section{Introduction}

Worsening of health and insufficient motion fitness of school age children is undoubtedly a serious problem [15]. That is why, at present, one of main tasks is control of strengthening of youth's health, formation of their demand in motion perfection and healthy life style.

Unfortunately, as on to day traditional physical culture lesson ensures, in average, up to $11 \%$ of required weekly motion functioning; about $50 \%$ of children have no steady interest to physical culture [5]. Most of specialists think that accent on increasing of physical culture-physical education work shall be realized in out of school forms of trainings.

Hat is why at present there is active implementation of innovative methodic in out of school educational establishments in order to achieve and maintain children's optimal physical condition, their motivation and individual features $[1,2,14]$.

These problems were reflected in Conception of out of school education and learning, in Laws of Ukraine "On education", "On physical culture and sports", in National doctrine of development of education, in National doctrine of physical culture and sports development, in decree of Council of Ministries of Ukraine "On approval of nomenclature of national educational establishments' types; principles of out of school educational establishments and National strategy of development of education in Ukraine for 2011-2016. The state ensures creation of all conditions for children's involvement in sports and motion functioning.

It is known that just motion fitness influences substantially on physical condition of a person. For example, it can improve health and mental state of a person (reduce risk of many diseases, strengthen "life tonus", activity and workability, regulate organism's functioning, improve mood, everyday self-feeling and so on). It improves physical condition (increases strength and endurance, flexibility and coordination); it improves posture (reduces quantity of fat, increase or reduce volume of muscles and etc.). Alongside with it motion fitness is interpreted as result of comprehensive development of motion abilities, functional potentials of organism's organs and systems, their coordination in process of muscular functioning $[6,9,15,20]$.

Analysis of health related practices witnesses that among girls one of the most popular kinds of health related physical culture is aerobic. Analysis of scientific methodic literature showed that high health related effect is reached exactly with aerobics' exercises $[3,5,11,12]$.

As on to day there have been researched and worked out great number of methodic and programs of aerobics' traininga [4, 7, 8, 10, 13, 16-19]; but the problem of demand in aerobics' trainings of 16-18 years old girls in out of school educational establishments has been still remaining urgent and insufficiently studied.

The work has been fulfilled in compliance with priority direction of scientific researches of Chernigov national pedagogic university, named after T.G. Shevchenko: Didactic principles of motion functions' formation of persons, practicing physical culture and sports", (state registration number 0108U000854, dt. February 19 $9^{\text {th }}, 2008$ ), "Pedagogic ways of formation of healthy life style of different age groups' schoolchildren" (state registration number 0112 U001072 dt. 18.01.2012).

Purpose, tasks of the work, material and methods

The purpose of the work is to analyze influence of health related aerobics' trainings on girls' motion fitness in out of school educational establishments.

The research was conducted on the base of methodic center of vocational training in Chernigov region and in Regional public organization "Federation of aerobics of Chernigovschina", Federation of aerobics in Odessa, studio of dance and aerobics "VerDikt", dancing center " 5 th element" and on the base of Chernigov national pedagogic university, named after T.G. Schevchenko.

For solution of our tasks, in academic health related process on aerobics at out of school educational establishment we introduce and carried out forming pedagogic experiment (we created experimental and control groups). Experimental (EG) group of girls was trained by offered by us methodic, control group (CG) - by traditional.

\footnotetext{
(C) Shypulo I. P., 2015

http://dx.doi.org/10.15561/20755279.2015.0110
} 
Trainings were conducted trice a week; 1 hour every training. Total scope and intensity of loads in both groups were equal. Trainings in CG were conducted in compliance with recommendations $[4,8,10]$.

The worked out by us structure of process of girls' motion development at aerobics' trainings at out of school educational establishments included: purpose; certain tasks, model indicators of development of motion abilities, health and motion progress; principles; control; scope of load; forms of trainings' organization; methods; system of pedagogic influences; practical application; health related result.

Exactly methodic of aerobic training of girls at out of school educational establishments includes five stages, which differ by particular tasks and purposes.

We conducted the following tests: 1 - long jump, cm; 2- "Shuttle run", sec.; 3- chin ups, q-ty of times; 4pressing ups in lying position, q-ty of times; 5 - taking sitting position from lying one (during 1 minute); 6- hanging on bent arms, sec.; 7- forward torso bending, cm; 8- dynamometry of backbone, $\mathrm{kg}$.

Testing was fulfilled at the beginning and at the end of experiment. Experiment lasted for three years.

Results of the research

Research of girls' (who train aerobics) motion fitness is very important for practice of training and education of rising generation. Exactly such researches permit to reveal all problems at aerobics' trainings and in changing of girls' individual abilities under influence of trainings, as well as to reveal motivation and interest to trainings.

By results of tests we determined girls' motion fitness in special health group (SHG) and in sport group (SG). example:

We found that in SHG, in comparison with SG (see fig.1) indicators of motion fitness were much worse. For

- In long running jump SHG girls' indicators: $121.30 \pm 5.17 \mathrm{~cm}$ and $198.52 \pm 7.28 \mathrm{~cm}$;

- In "Shuttle run": $16.84 \pm 1.43 \mathrm{sec}$. and $10.55 \pm 1.04 \mathrm{~min}$.;

-In chin ups, SHG groups' girls had $2.58 \pm 0.27$ times and 5.04 \pm 0.51 timers;

- In pressing ups in lying position SHG indicators were 16.77 \pm 1.71 times and in SG $30.53 \pm 3.15$ times;

- Taking sitting position from lying one (during 1 minute) in SHG - 23.52 \pm 2.42 times and in SG - 45.00 \pm 3.94 times;

- Indicators of hanging on bent arms in SHG were 22.28 $\pm 2.51 \mathrm{sec}$. and in SG - 41.68 $\pm 4.31 \mathrm{sec}$;

- Indicators of forward torso bending in SHG were $13.93 \pm 1.41 \mathrm{~cm}$ and $26.68 \pm 2.70 \mathrm{~cm}$;

- Indicators of backbone dynamometry were in SHG $32.79 \pm 3.34 \mathrm{~kg}$ and in SG - $59.74 \pm 6.10 \mathrm{~kg}$.

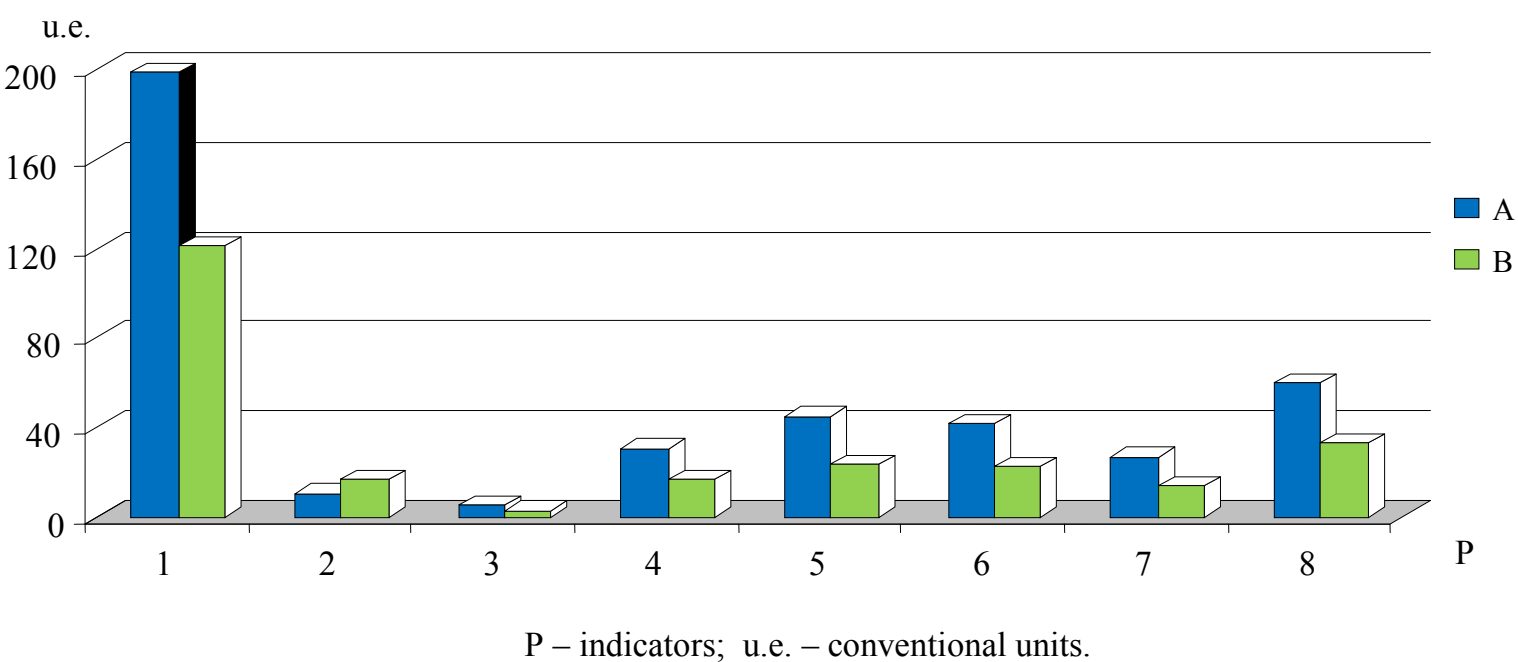

Fig. 1. Mean statistical results of motion fitness of SHG (A) $S G(B)$ girls:

1 - long jump, cm; 2 - "Shuttle run", sec.; 3 - Chin ups, q-ty of times; 4 - Pressing ups in lying position, q-ty of times; 5 - Taking sitting position from lying one (during 1 minute); 6 - Hanging on bent arms, sec.; 7 - Forward torsi bending, $\mathrm{cm} ; 8$ - Back dynamometry, $\mathrm{kg}$.

It was determined that girls of sport group had better motion fitness. The received data permit to rather objectively prognosticate results with purposeful, comprehensive girls' trainings of aerobics.

Correlation analysis permitted to determine the most informative girls' indicators. The received indicators are interconnected and influence on girls' physical fitness.

On the base of the obtained data we built graphic analytic model for quantitative and qualitative control, which also permits to prognosticate development of girls' motion fitness (see fig.2). 


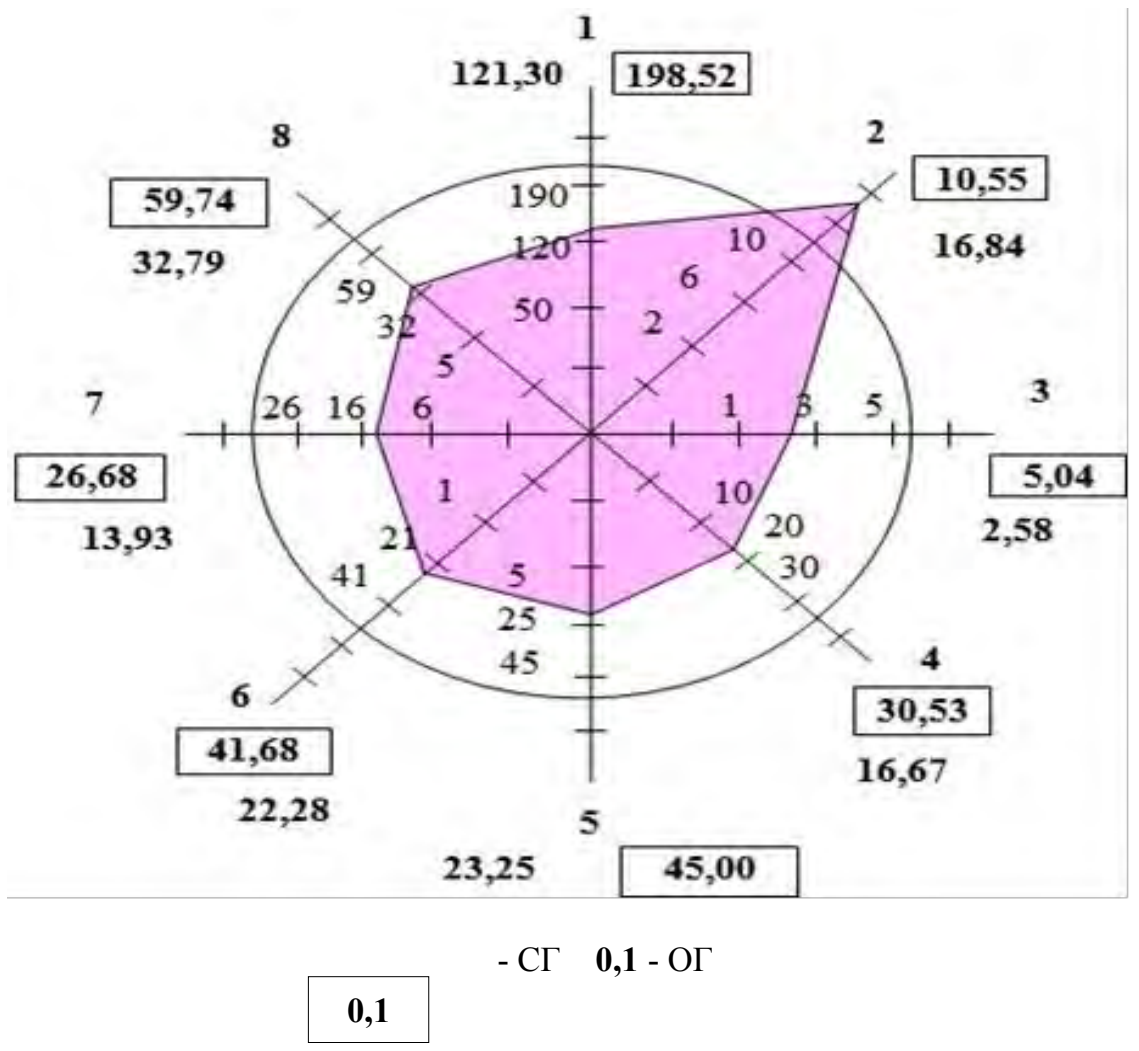

Fig.2. Graphic analytical model of motion fitness of health related (SHG) group's girls and sport group's (SG) girls: 1 - shuttle run; 2 - forward torso bending; 3 - taking sitting position from lying one during 1 minute; 4 - backbone dynamometry (torso); 5 - long jump; 6 - chin ups; 7 - hanging on bent arms; 8 - pressing ups in lying position.

Analysis of aerobic trainings' influence on girls' motion fitness showed that in EG it improved by $37 \%$, and in $\mathrm{CG}-$ by $23 \%$ (see fig. 3 ).

u.e.

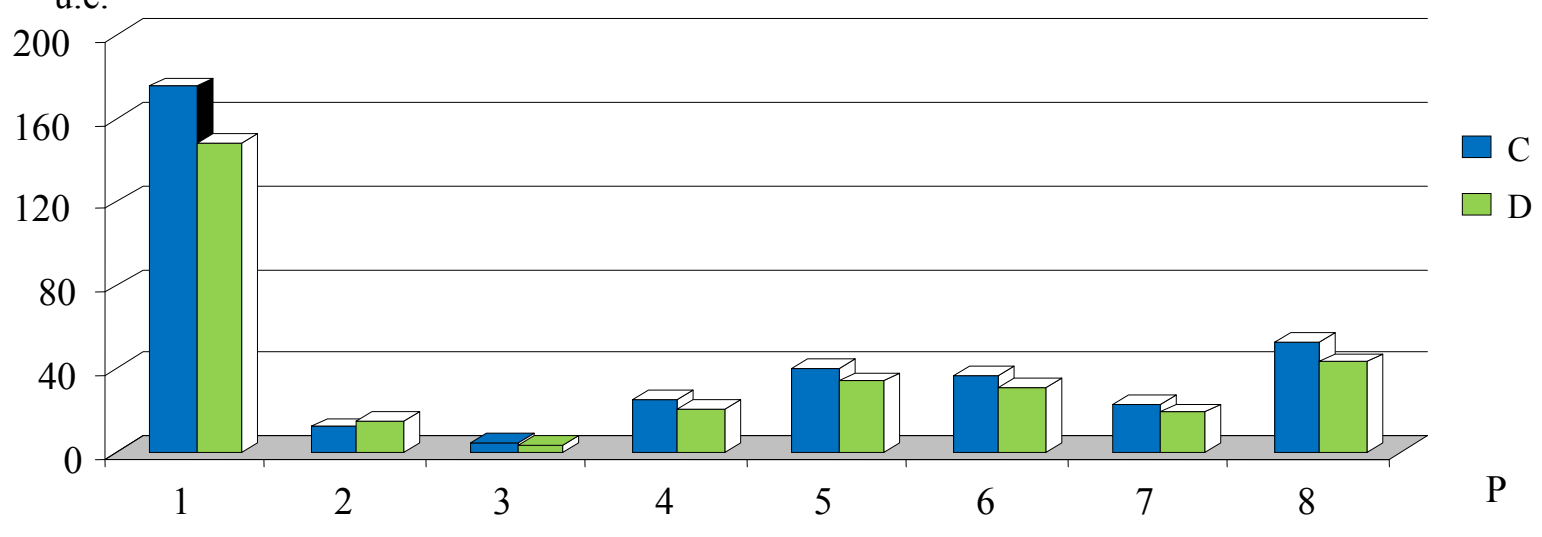

$\mathrm{P}$-indicators; u.e. - conventional units.

Fig.3. Comparison of motion fitness of experimental group's girls $(C)$ and control group's girl (D):

1 - shuttle run; 2 - forward torso bending; 3 - taking sitting position from lying one during 1 minute; 4 - backbone dynamometry (torso); 5 - long jump; 6 - chin ups; 7 - hanging on bent arms; 8 - pressing ups in lying position.

The received EG indicators are much better than indicators of $\mathrm{CG}$ and witness that introduction of experimental methodic was rather useful.

\section{Discussion}

In the whole, in context of improvement of girls' motion fitness our data are accorded quite satisfactory with ideas of other authors $[4,7,8,10,13,16-19]$. Alongside with it approaches, recommended by us, differ a little from commonly accepted by the following:

- complex approach to application of aerobics for comprehensive girls' development;

- at aerobics' trainings we used new and variable means and methods; 
- development of girls' motion skills was realized with accurate dozing of loads' parameter and their control at every training;

- realization of health, functional state and motion fitness control контроль took place at every training, every week, every month for determination of loads' parameters and diagnostic of dynamic of indicators' change;

- in power part of every training we paid attention to development of legs', arms' and torso muscles; and etc.;

- we also paid attention to perfection of coordination, videlicet: dexterity, jumping ability, balance, rhythm

- in warming up and final parts of every training we paid attention to flexibility;

- trainings were conducted with application of aerobics' health related exercises, which were based on prognostic graphic analytical models;

- for evaluation of initial data of girls' motion fitness we used bio-mechanical indicators except generally accepted characteristics; monitoring.

- correction of girls' motion fitness at aerobics' trainings was realized on the base bio-mechanical

In general results of pedagogic experiment completely prove our opinion about solution of increasing of girls' motion fitness at out of school educational establishments.

Conclusions:

1. Testing of effectiveness of pedagogic experiment showed that purposeful education-learning process of health related aerobics improves girls' motion fitness.

2. The received indicators of girls' motion fitness are maximally close to model indicators.

3. Application of the newest means and methods will vary aerobics' trainings of 16-18 years' old girls.

\section{References:}

1. Bulatova M.M. Fitnes i dvigatel'naia aktivnost': problemy i puti resheniia [Fitness and physical activity: problems and decision ways]. Teoriia i metodika fizicheskogo vospitaniia i sporta, 2007, no.1, pp. 3-7. (in Russian)

2. Zinchenko V.B., Usachev Iu.A. Fitnes-tekhnologii v fizicheskom vospitanii [Fitness technology in physical education], Kiev, NAU, 2011, 152 p. (in Russian)

3. Ivlev M.P. Soderzhanie $i$ metodika zaniatij ritmicheskoj gimnastikoj s zhenshchinami zrelogo vozrasta. Kand.dis. [Content and methodology of employment by rhythmic gymnastics with women of mature age. Kand.dis.], Moscow, 1987, 23 p. (in Russian)

4. Krivoruchko S.N., Panasejko Iu.G., Belous N.S. Aerobika na zaniatiiakh po fizicheskom vospitaniiu [Aerobics on physical education classes], Kharkov, KHAI, 2012, 56 p. (in Russian)

5. Krucevich T.Iu., Bezverkhniaia G.V. [Formation of motivation in physical education and sport at school age]. Olimpijskij sport i sport dlia vsekh. Problemy zdorov'ia, rekreacii, sportivnoj mediciny i reabilitacii, IV Mezhdunarodnyj nauchnyj kongress [Olympic sport and sport for all. Health problems, recreation, sports medicine and rehabilitation. IV International Scientific Congress], Kiev, 2000, pp. 385. (in Russian)

6. Kuzemko L.M. Razvitie fizicheskikh kachestv [Development of physical qualities], Chernigov, 2008, pp. 108-146. (in Russian)

7. Lisickaia T.S., Sidneva L.V. Aerobika [Aerobics]. Moscow, Federation aerobics, 2002, no.2, 232 p. (in Russian)

8. Bachinskaia N.V., Lapuga G.V. Uchebnye zaniatiia po aerobike [Teaching aerobics classes], Dnepropetrovsk, RVVDNU, 2011, 52 p. (in Russian)

9. Nosko N.A., Arkhipov A.A. [Quality motor as the main criteria of human motor function]. Vestnik Chernigovskogo nacional'nogo pedagogicheskogo universiteta. 2013, no.2, pp. 25-29. (in Russian)

10. Abdullin M.G., Gimranova L.V., Lopatina Z.F., Rylova E.V., Khalitova O.Iu. Ozdorovitel'naia aerobika [Improving aerobics], Ufa, Bashkir State Pedagogical University Publ., 2010, 64 p. (in Russian)

11. Rajcina L.P. [Sports and dance aerobics in high school]. Materialy IY mezhvuzovskoj nauchnoprakticheskoj konferencii «Fizicheskoe vospitanie $i$ sport uchashchejsia molodezhi». [IY Interuniversity Scientific and Practical Conference "Physical education and sport students."]. Moscow, MGIU, 1998, pp. 12 - 13. (in Russian)

12. Rostovceva M.Iu. Povyshenie fizicheskoj rabotosposobnosti zhenshchin molodogo vozrasta sredstvami ritmicheskoj gimnastiki. Kand.dis. [Increase physical performance young women by means of rhythmic gymnastics. Kand.dis.], Malahovka, 1990, 24 p. (in Russian)

13. Sinica S.V., Shesterova L.E. Ozdorovitel'naia aerobika [Improving aerobics], Poltava, PNPU, 2011, 236 p. (in Russian)

14. Usachev V.I. Sposob kachestvennoj ocenki funkcii ravnovesiia [A method of qualitative evaluation of balance function]. Patent UA, no. 2175851, 2001. (in Ukrainian)

15. Khoroshukha M.F. Osnovy zdorov'ia iunykh sportsmenov [Health basics of young athletes], Kiev, NUBiP Ukraine, 2014, 722 p. (in Russian)

16. Shevchenko O.Iu. [Influence of improving aerobics on the functional state]. Olimpijs'kij sport $i$ sport dlia vsikh. 14 Mizhnarodnij naukovij kongres [14 International Scientific Congress. Olympic sport and sport for all], Kiev, 2010, pp. 639. (in Ukrainian) 
17. Céline Aguer, Olivier Gavarry, Yoann Gole, Alain Boussuges, Pierre Doyard, Guy Falgairette. A 5-month weight-reduction programme has a positive effect on body composition, aerobic fitness, and habitual physical activity of severely obese girls: A pilot evaluation study. Journal of Sports Sciences. 2010, vol.28, no.3, pp. 281-289.

18. Marcus Wayne Kilpatrick, Amy Lynn Bortzfield, Lisa Marie Giblin. Impact of aerobic exercise trials with varied intensity patterns on perceptions of effort: An evaluation of predicted, in-task, and session exertion. Journal of Sports Sciences. 2012, vol.30, no.8, pp. 825-832.

19. Melitta McNarry \& Andy Jones. The influence of training status on the aerobic and anaerobic responses to exercise in children: A review. Journal: European Journal of Sport Science. 2014, vol.14, no.1, pp. S57S68.

20. Stuart J.H. Biddle, Rock Braithwaite, Natalie Pearson. The effectiveness of interventions to increase physical activity among young girls: A meta-analysis. Preventive Medicine, 2014, no.62, pp. 119-131.

Information about the author:

Supilo I.P.: http://orcid.org/0000-0003-0911-0460; verdikt_aerodance@ rambler.ru; Chernihiv National Pedagogical University; Str. Polubotko Getman, 53, Chernigov, 14013, Ukraine.

Cite this article as: Shypulo I. P. Influence employment by improving aerobics on motor readiness of girls. Physical education of students, 2015,no.1,pp.67-71.http://dx.doi.org/10.15561/20755279.2015.0110

The electronic version of this article is the complete one and can be found online at: http://www.sportpedu.org.ua/html/arhive-e.html

This is an Open Access article distributed under the terms of the Creative Commons Attribution License, which permits unrestricted use, distribution, and reproduction in any medium, provided the original work is properly cited (http:// creativecommons.org/licenses/by/3.0/deed.en). 
2015

- (0) 1 


\section{SUBMISSION OF MANUSCRIPTS}

(For more detailed information see http://www.sportpedu.org.ua/html/trebovaniya-e.html)

Structure of article:

- title of an article;

- surname, full first name and patronymic;

- full name of organization (place of work or study);

- annotation in three language (Russian, Ukrainian, English). The scope of the annotation is to be $800-1000$ symbols. Annotation must contain

translate of surname, full first name and patronymic of authors, in Ukrainian (Russian) and English. Structure of annotation: aim, material, result.

For authors from Russia, the translation in the Ukrainian language makes editorial board.

- Key words for the three languages: ( 1-2 lines of words. Do not use word combinations).

- Introduction (statement of a problem; analysis of the last researches and publications of this theme; to single out the open problem in the research article).

- Connection of the article with important scientific programs or practical tasks.

- Aim, tasks, material and methods.

- Results of the research (description of the main research material with full substantiation of the derived scientific results).

- Findings.

- Perspectives of future researches in this direction.

- Bibliographic references (more than 20) should be making up according to standard form.

REVIEW PROCEDURE FOR MANUSCRIPTS (For more detailed information see http://www.sportpedu.org.ua/html/recenzirovaniye-e.html) All manuscripts submitted for publication must go through the review process.

TREATMENT OF MANUSCRIPTS (For more detailed information see http://www.sportpedu.org.ua/html/rassmotreniye-e.html)

Manuscripts are assessed by the Editorial Board within 1 month.

The Journal will acknowledge receipt of a manuscript within 2 days.

EDITORIAL ETHICS (For more detailed information see http://www.sportpedu.org.ua/html/ethics-e.html)

The journal is committed to a high standard of editorial ethics.

Editorial board is used the principles of ethics of scientific publications upon recommendations of International Committee of Medical Journal Editors.

Conflicts of interests of persons who have direct or indirect relation to the publication of an article or any information that the article consist are settled according to the law of Ukraine in the field of intellectual property.

\section{CONTACT INFORMATION}

box 11135, Kharkov-68, 61068, Ukraine

phone. (38057) 755-73-58

http://www.sportpedu.org.ua

e-mail: sportart@gmail.com 
Information Sponsors, Partners, Sponsorship:

- Belgorod State Shukhov Technological University,

- National Research University Belgorod State University,

- Olympic Academy of Ukraine,

- Ukrainian Academy of Sciences.

\section{SCIENTIFIC EDITION (journal)}

Physical Education of Students. 2015, no.1, 76 p.

Editorial to the publisher department KSPU:

certificate DK №860 20.03.2002.

designer - Masterova Y.

editing - Yermakova T.

administrator of sites - Ulanchenko Y.

designer cover - Bogoslavets $\mathrm{A}$.

passed for printing 30.12.2014

Format A4.

PRINTHOUSE (B02 № 248 750, 13.09.2007).

61002, Kharkov, Girshman, 16a. 